



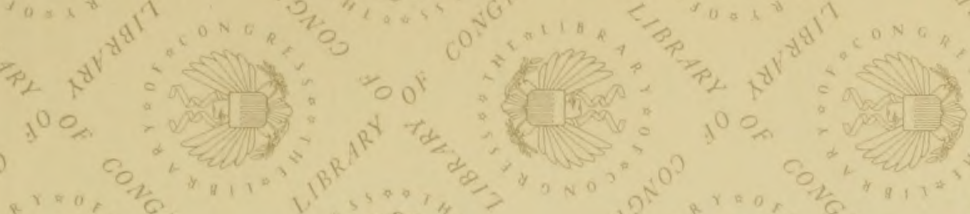

*

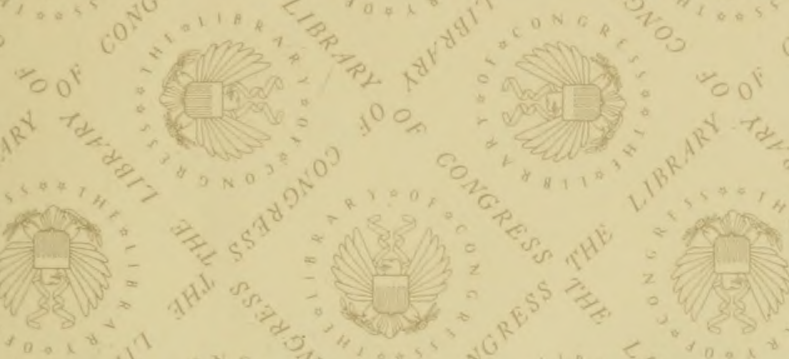

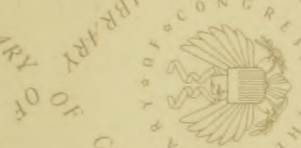

(n)

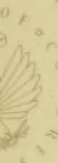

$1 \% 0$

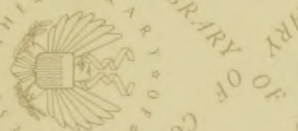

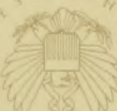

क्विये

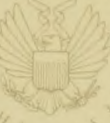

हो

क्षित्री

100

(स) न

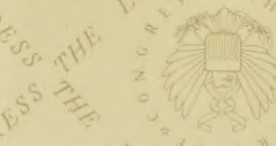

\section{a}

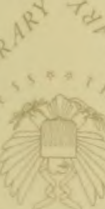

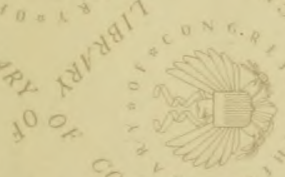

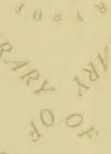

a)

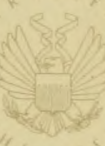

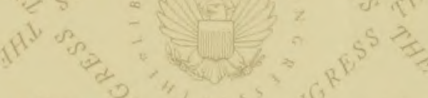

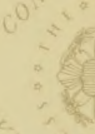

\section{SIII)}

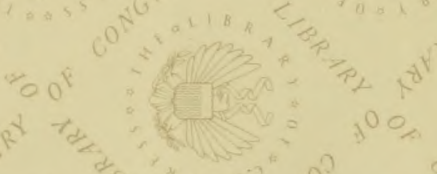

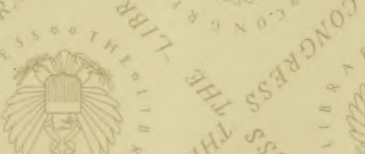
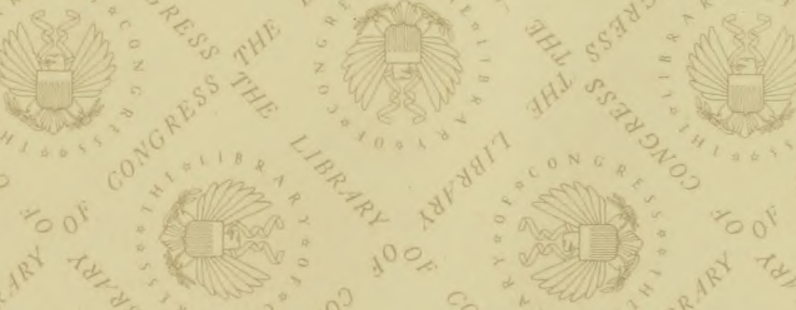

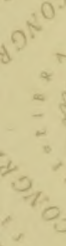

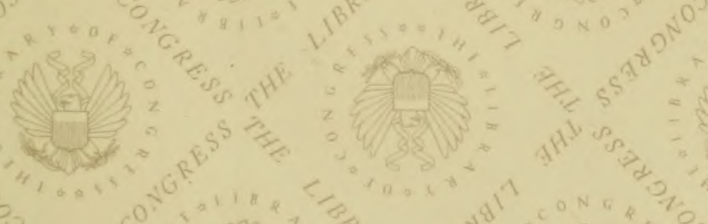

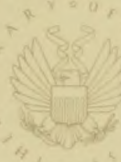

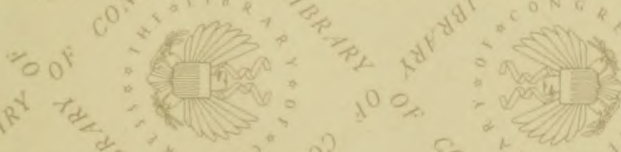


(20) and

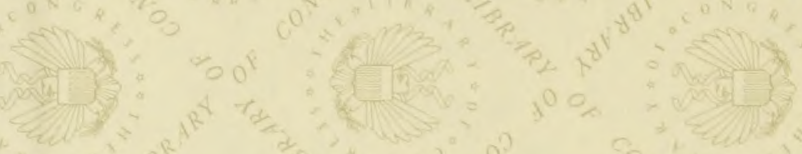

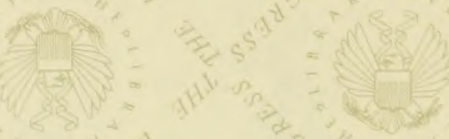

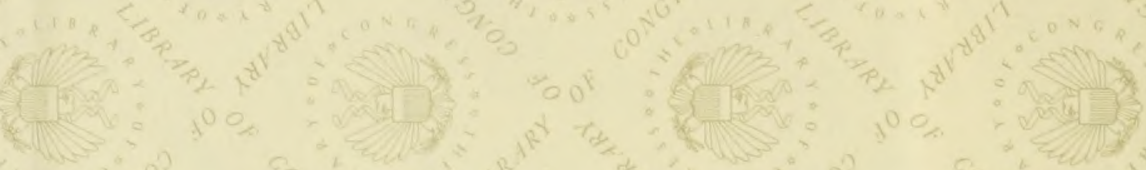

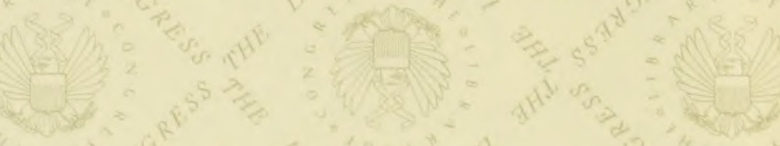

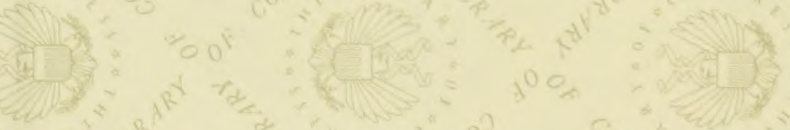

Q

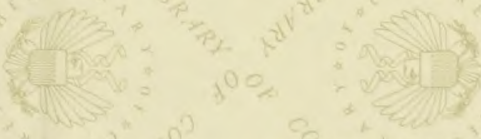

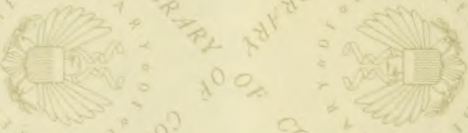

(x)

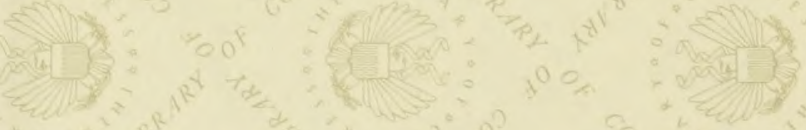
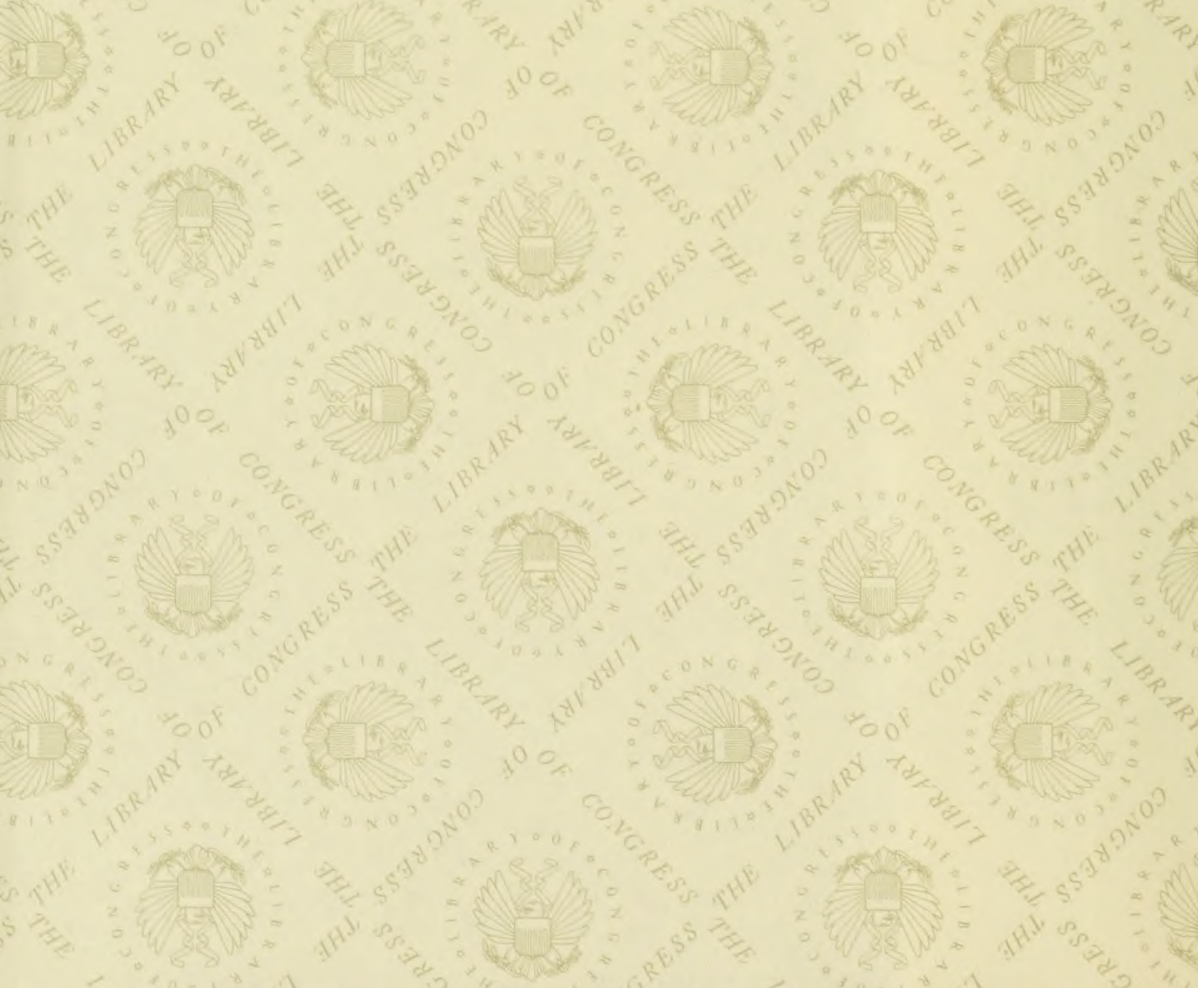

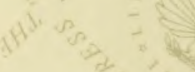

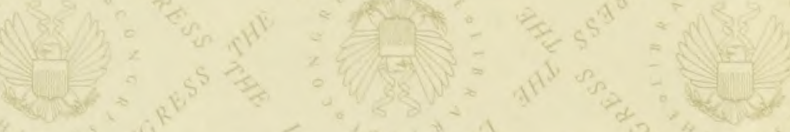






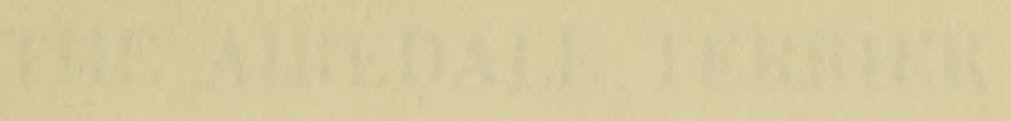





\title{
THE COMPLETE STORY OF
}

\section{THE AIREDALE TERRIER}

\author{
BY \\ F. M. JOWETT
}

WITH AN INTRODUCTION AND AN ARTICLE ON THE BREED AND BREEDERS IN AMERICA BY ARTHUR B. PROCTOR

THE OFFICIAL YEAR BOOK

OF THE AIREDALE TERRIER CLUB

OF NEW ENGLAND

1913

PUBLISHED BY

ARTHUR B. PROCTOR

NEW YORK 


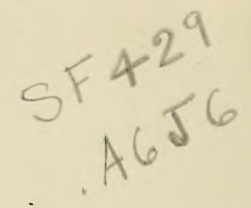

Copyright, 1911 ,

Dogs in America Publishing Co.

Copyright, 1911 ,

Oceanic Publishing Co.

Copyright, 1913,

By Arthur B. Proctor

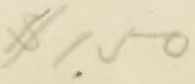




\section{TABLE OF CONTENTS}

CHAPTER

P.MTE

Introduction by Arthur B. Proctor . . . . . . . xi

Preface . . . . . . . . . . . . $\mathrm{xV}$

i Origin and History of the Airedale Terrier . . . . 3

il Recent History . . . . . . . . . . . . . 17

III How to Breed Winners . . . . . . . . . . 25

iv The Care of the Brood Bitch . . . . . . . . 41

r The Selection and Rearing of Puppies . . . . . 53

vi How to Train and Condition for the Show Ring • . 63

vil Points where Improvfinent is Still Needed • . . . 75

vil The Versatility of the Airedale Terrier . . . . 81

ix Description of the Ideal Airedale Terrier and

OfFichal Standard . . . . . . . . . . 87

JUDGES IN 1911 AND 1912 . . . . . . . . . . 90

English Champions of Record . . . . . . . . 93

American Champions of Record . . . . . . . 97

Canadian Champions of Record . . . . . . . 99

Dogs Taking Winners in 1911 and 1912 . . . . . 100

Bitches Taking Winners in 1911 and 1912 . . . . 101

Breeders and the Breed in America,

by Arthur Bothwell Proctor . . . . . . . . 105

Airedale Terrier Cludbs in England . . . . . . 125

Atredale Terrier Clubs in America . . . . . . 133

The Airedale Terrier Cujb of New England . . . 143

Breeders' and Kennel Directory . . . . . . . 165

Classified Advertisements . . . . . . . . . 171 



\section{LIST OF ILLUSTRATIONS}

Head Study of Ch. Kenmare Sorceress . . . . Front cover Mr. F. M. Jowett . . . . . . . . . . Frontispiece PAGE

1Ir. Arthur B. Proctor with Bothwell Builder and Bothwell Sorceress . . . . . . . . . . . . . . $x$ First Illustration of an Airedale Terrier and Broadlands Brushwood . . . . . . . . . . . . . . xiv Old English Print of an Airedale Terrier . . . . . . xvi Ch. Newbould Test and Ch. Wharfedale Rush . . . . . 2 Tiger Mlonk . . . . . . . . . . . . . . . 3

Ch. Cholmondeley Briar and Airedale Jerry . . . . 6

Ch. Dumbarton Lass and Ch. Master Briar . . . . . . 9

Ch. Tintern Royalist . . . . . . . . . . . . 13

Bothwell Sorceress at Three Months . . . . . . . . 14

Dargle Declare . . . . . . . . . . . . 16

Ch. Kootenai Radiance . . . . . . . . . . . . 17

Studholme Snowball and Giltrap . . . . . . . . 18

Briarwood and Crompton Marvel . . . . . . . . 20

Ch. Soudan Swiveller . . . . . . . . . . . . 24

Head Study of Ch. Prince of York . . . . . . . . 25

Ch. York Masterpiece and Ch. York Sceptre . . . . . . 26

Ch. Soudan Stamboul . . . . . . . . . . . . . . . 29

Abbey Master Magic . . . . . . . . . . . . 33

Ch. Abbey King Nobbler . . . . . . . . . . . 38

Ch. Kenmare Sorceress . . . . . . . . . . . . 40

Ch. Larchmere Mistress Magnet . . . . . . . . . 41

Clonmel Imperious . . . . . . . . . . . . . 43

Soudan Sapphire and Dumbarton Vixen . . . . : . 45

Virkery Vesta . . . . . . . . . . . . . . 47

Ch. Dargle Deputy . . . . . . . . . . . . . 49

A Typical Litter of Puppies, American-bred . . . . . 52

A Brace of Four Months Bothwell Pups . . . . . . . 53

Mrs. Crawford with Lodestar . . . . . . . . . . 54 
A Typical Litter of English Puppies .

Ch. Prince of York .

Head Study of Ch. Tintern Royalist . . . . . . . . 63

Ch. Tintern Royalist . . . . . . . . . . . . 65

Elruge HIonarch . . . . . . . . . . . . . . 69

Ch. The Norseman and Hot . . . . . . . . . . 71

Ch. Briars Masterpiece . . . . . . . . . . . . 74

Imperious Oorang . . . . . . . . . . . . . 75

Ch. Clonmel Monareh . . . . . . . . . . . . 77

The Vickery Kennels . . . . . . . . . . . . 78

Bothwell Builder . . . . . . . . . . . . . 80

Rats Killed by an Airedale . . . . . . . . . . . 81

Otis Airedales Afield . . . . . . . . . . . . . . 82

Otis Diana . . . . . . . . . . . . . . . 83

Airedales Doing Police Work . . . . . . . . . . 84

Model of an Airedale Terrier . . . . . . . . . . 86

Head Study of Ch. Soudan Stamboul . . . . . . . . 87

Model of an Airedale Terrier . . . . . . . . . . . . 89

Mr. Theo. Offerman . . . . . . . . . . . . . 90

Ch. King Oorang . . . . . . . . . . . . . 92

Ch. Red Raven . . . . . . . . . . . . . . 96

Mr. Jas. W. Spring Judging at Long Branch in 1911 . . . 102

Vickery Lodestar . . . . . . . . . . . . . 104

Ch. Bolton Woods Briar . . . . . . . . . . 106

Ch. Pilgrim Yellow Jacket . . . . . . . . . . . 110

Ch. Thayerdale Tenny . . . . . . . . . . . . 113

Ch. Kismet Flashlight and Arnecliff Jacobite . . . . . 116

Otis Brunette at Six Months . . . . . . . . . . 119

Ashbourne Frills . . . . . . . . . . . . . 122

Pretty Florrie . . . . . . . . . . . . . 123

Painting of Ch. Tintern Royalist . . . . . . . . . 125

Picture of Ch. Prince of York, taken in England . . . . 133

Ch. T'anglewold Una . . . . . . . . . . . 164

The Late Alex. Smith with Ch. Tintern Royalist . . . . 171 



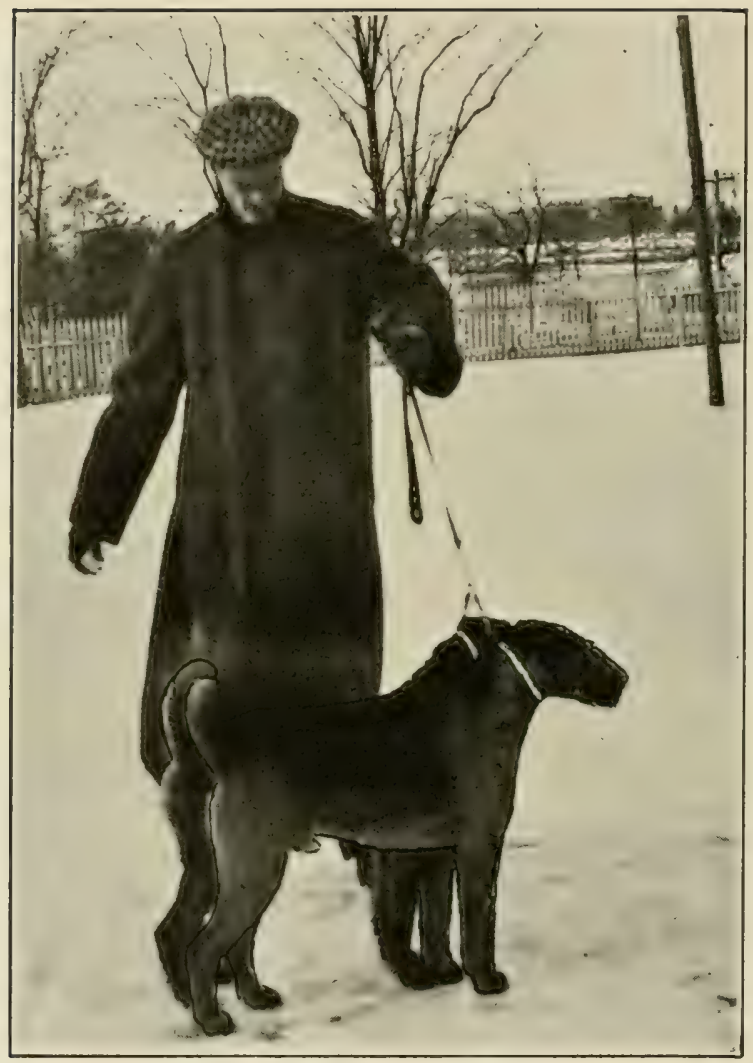

MR. ARTHUR B. PROCTOR

With Team of 6. Months Old Prince of York Pups, Bothwell Builder and Bothwell Sorceress 


\section{INTRODUCTION}

WHEN this story was published serially last year, it universally created farorable comment, both here and in England, as being just what was needed in the way of a standard of the Airedale Terrier, and the copies of the paper containing it were soon at a preminm and hecame quickly out of print. Then a spontaneous demand for its publication in book form started in and has been growing steadily - a demand that seems to be equally divided between the layman and the veteran fancier.

The reason is plain, for with the exception of the brochure of an English contemporary, there is no book devoted to the breed that has been written by one who so thoroughly knows his subject. We feel confident that this book will fill a long felt want and with the many added features be a constant and ready book of reference in the library of not only Airedale men but all wire-haired terrier men.

MIr. F. MI. Jowett, its anthor, is a shining light in the English kennel world, being one of the greatest breeders, most astute judges and a writer of no mean reputation, making that so rarely seen combination of a man who knows his subject from $\mathrm{A}$ to $\mathrm{Z}$ and is (apable of presenting it in such a clear and charming manner that all he writes is keenly read and the words of wisdom absorbed almost unknowingly.

Being horn in the Aire Valley in Yorkshire and living to-day in Shipley, harely three miles from Bingley, sometimes called the cradle of the breed; and having spent his entire life among dogs, Mr. Jowett has oltained the knowledge he possesses which makes lim famous as breeder and judge, more especially of Airedale and Irishl Terriers. For over twenty years he has lent distinction to the judging ring at England's greatest shows, and has five times had the honor of adjudicating on Airedale Terriers at Otley, that little 
Yorkshire market town where for so many years it was the greatest ambition of the breeder to win the gold medal offered at that show for the best of the breed; and he judged Airedales at the English Kennel Club Show of 1912, at the Palace.

MIr. Jowett was early associated with this dog in its making and infancy, as his father bred the old English wire-haired black and tan terriers, the base which, bred to the Otter Hound, produced the dog we have to-day ; and reference to the first illustration of a terrier and comparison with some of our present-day wimners will show under what difficulties hreeders have had to work and explain why so rarely even to-day a really good one is produced.

As a young man being intimately associated with the breed in its inception and an eye-witness to the struggles to improve the dog, none can so well realize the reasons for the difficulties encountered by the novice, and is so fitted to guide his steps along the road to knowledge, or to warn him of the many pitfalls so easily fallen into.

The thanks of all Airedale Terrier men in Ameriea, and particularly all novices, are due to $\mathrm{Mr}$. . Jowett for first presenting to them in written form what he knows about the biggest and best terrier; and how badly such a message is needed is indicated by the demand for every paper or book that has appeared containing any items about the breed, no matter how poorly written or erroneous in the facts contained.

The story opens up with the infancy of the breed; "how those dead-game sports, Yorkshire working men, set out to fishion a terrier that would he speedier, stronger, higger and gamer than the good old black and tan terrier of the neighborhood in the riverside ratting contests which furmished one of the farorite amusements." Then he elearly explains the good points of the parent breed and the faults the breeder has to start to breed out. He will introduce you to the breeders and the dogs from which they evolved the present-day terrier up to Champion Cholmondeley Briar, from whom every good dog of to-day descends; then, describing him in detail, he does the same with his famous descendants right down to some of the terriers shown at the New York Show in 1911. Then he presents the results of his experience in the care of the stud dog and brood bitch, much of the information contained being new and of interest to breeders in general, with a most useful chapter on the Selection and Rearing of Puppies-and right here is the crux of the whole breeding situation and the explanation of why the English 
have been so much more successful than we have in rearing good show specimens. Then follows a chapter on Preparing and Conditioning for the Show Ring, and Mr. Jowett says, "I hope to enable the small amateur breeder, who may breed one litter a year, - and such men are the backbone of the fancy in England, - to take a shorter road to success than they would, perhaps, have been able to do if left to their own unaided efforts." This chapter, along with the one on Points Where Improvement is Still Needed, would make the book incomparahle if they were its sole contents. The last chapters are on the Versatility and the Description of the Ideal Airedale and Standard of Points, and the addition by the editor of an article on the Breed and Breeders in America is perhaps superfluous, except that it may prove interesting to the future novice.

Mr. Jowett has his subject so well in hand, and is so gifted with the ability to express himself in lueid form, that he has embodied a volume of information and advice in a very small compass, making it unnecessary to wade through many pages of superfluous matter to learn practically all that ean be written about this sterling terrier. To make this into a book rather than a brochure, the publisher has been at great pains to gather together a great deal of material pertaining to the Airedale, a portion of which has never before been compiled.

In consequence, a list of the Airedale Terrier Clubs and their officers, of Airedale Kennels and their addresses, and a complete compilation of all the Champions of Record, both in England and America, have been added.

The publisher will appreciate the criticisms of all the breeders of the Airedale Terrier, and will welcome and be pleased to take adrantage of suggestions tending to improve this work in the second edition which he hopes soon to be enabled to bring out.

Arthur Bothwell Proctor. 


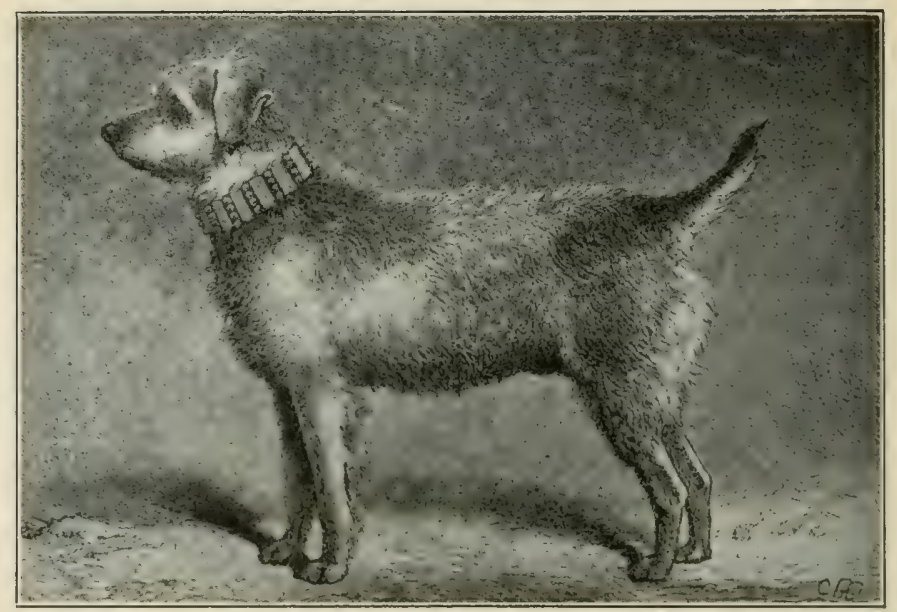

FIRST ILLUSTRATION OF AN

AIREDALE TERRIER， 1879

From Shaw's Book of the Dog

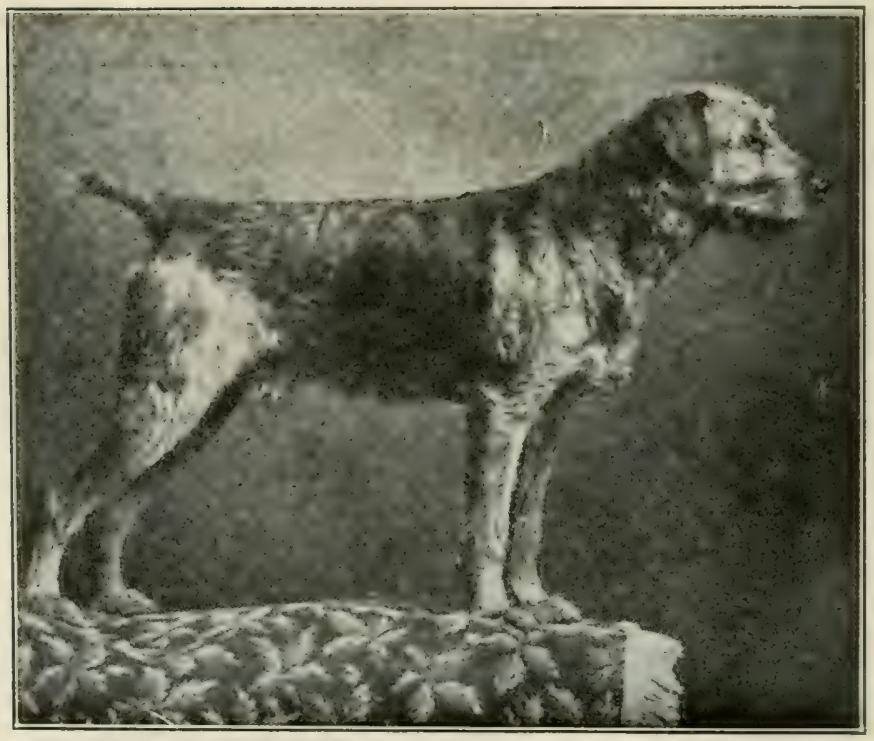

BROADLANDS BRUSHWOOD

First Airedale Terrier Shown in America 


\section{PREFACE}

I wortid like to explain here, on the page allotted to me for a Preface, that $m y$ friend, the late $M \mathrm{r}$. Frank II. MI.C'onnell, induced me to write some articles on the Airedale Terrier, with the idea that they might be of some value to American fanciers of the breed.

These articles were published serially, and I was told that they proved to be so popular that the numbers in which they were published were soon sold out, and there was a great demand for more.

Mr. Meconnell again approached me and asked if I would consent to write a book along the same lines as the articles.

This I consented to do, but his sudden death on the steamship "Baltic," while crossing from England to America,-which was a terrible shock to his many friends both in England and America, to whom he had endeared himself hy his kindly and genial personality, - has prevented their publication until Mr. Proctor approached me and offered to purchase the manuseript and the English and American rights to same.

I must say, first of all, that this book makes no pretence at all to literary value. I have tried to use the plainest and simplest language, so that it should be intelligible even to the veriest novice. I have written it with an idea of helping young heginners in the breed, and if, by giving them the benefit of my own practical experience, I can help them to take a shorter road to success than they would have been able to take by their own unaided endeavor's, then I shall feel pleased and more than satisfied.

I also hope that I may be able to remind older fanciers of something that they may, perhaps, have forgotten or overlooked.

I renture to say that the chapters on How to Breed Winners, The Care of the Brood Bitch, The Selection and Rearing of Puppies, and Ifow to Train and Condition for the Show Ring, will he found to be thoroughly practical, as they are the result of nearly thirty year's' experience, and if they are carefully studied they are hound to do a young fancier good. 
With much diffidence I may say that I am, perhaps, peculiarly qualified to write on the Airedale Terrier, as I was born and have lived all my life in Airedale, where the Airedale Terrier originated, and from which place it derived its name. I knew the first men who interested themselves in the breed, and remember the first dogs that were exhibited as Airedale Terriers. Coming from a family that have been associated with Hounds and Terriers for many generattions, my own first show dogs were naturally these local Airedale Terriers, and I owned some good winners in the early eighties; and although for many years I kept nothing but Irish Terriers in my keunel,-of which breed I have bred sixteen Champions, which is easily a world's record, - yet I have always kept in close touch with Airedale Terriers, and may be said to have grown with the breed. and have continually judged them at the hest shows, both in England and abroad, for twenty years.

F. M. JowetT.

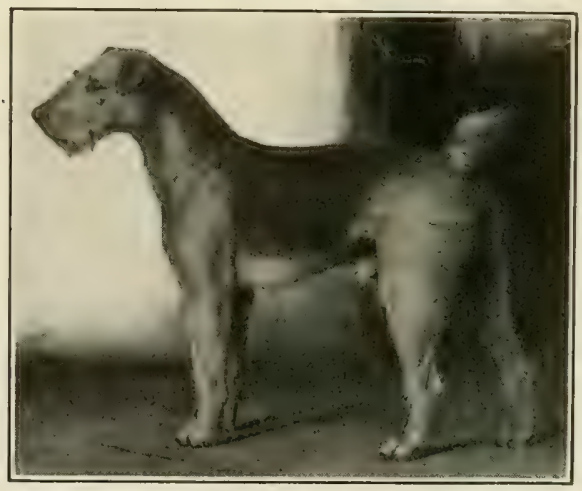

OLD ENGLISH PRINT OF

AN AIREDALE TERRIER

Property of A. B. Proctor 
THE COMPLETE STORY OF THE AIREDALE TERRIER 


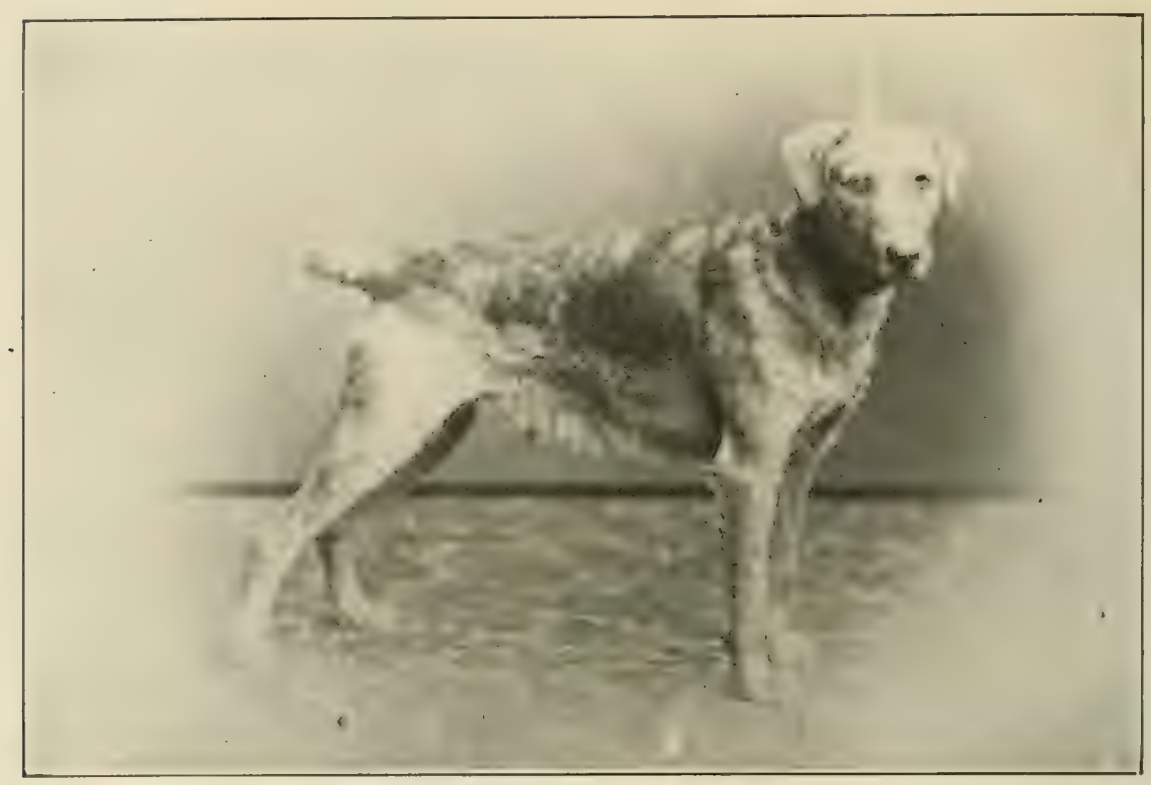

CH. NEWBOULD TEST

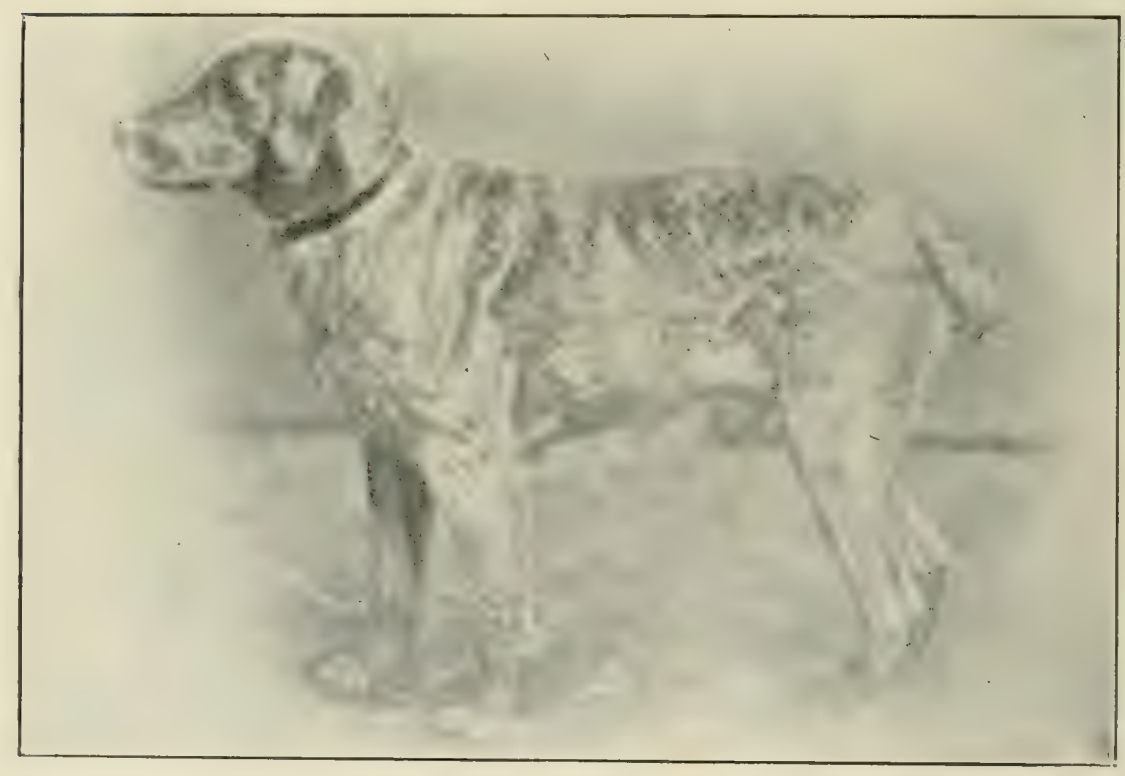

CH. WHARFEDALE RUSH 


\section{CHAP'TER I}

ORIGIN AND IISTORY OF THE AIREDALE 'TERIRIER

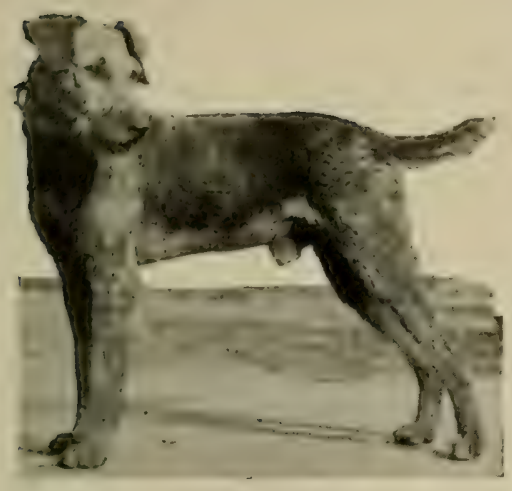

TIGER MONK

Tne Airedale Terrier was originally created by working men resident in Airedale, which is a manufacturing district in the West Riding of Yorkshire, England, and more particularly in that portion of Airedale which lies between Skipton and Bradford, a stretch of country of about twenty miles, which embraces the townships of Cononley, Silsden, Keighley, Bingley and Shipley.

This is one of the greatest sporting districts in a county that has always prided itself on its sportsmen, and it may perhaps help to illustrate the sport-loving nature of the men who made this famous 'Terrier,-which on its intrinsice merits as an all-round sporting 'Terrier, is now known and loved by sportsmen in all parts of the world, - if I attempt to give a rough outline of the sports and pastimes these men indulged in on the idle Saturday afternoons and summer evenings when their work was done.

Thirty years ago-in my youth - when the local trade was good and money plentiful, one could take one's choice any fine Saturday afternoon between seeing a whippet race for anything up to $t^{\prime} 50$ a side; a knur and spell match - a most popular game in Yorkshire in those days, matehes being played for as much as $£ 100$ a side; a cricket match between the rival townships, when the local rivalry was at bloor heat; a main of gamereorks fighting; or a waterside hunt down the banks of the river Aire after water rats.

Wany a rare day's sport have I had at this waterside hunting whon I was a youth, and possibly to those who have never had an 
opportunity of seeing the Airedale 'Terrier at work in his mative dale, a deseription of one of the hunts may perhaps be of interest.

'The usual arrangement was to hunt a portion of the river Aire - from which the dale takes its name-of from three to six miles, which is about the distamee from one township to another.

Matches would be made for stakes of anything from til to $t 20$ or t25 a side, sometimes for even higher stakes. A "mark" would count two points and a "kill" one point, the terrier making the most points at the finish being declared the winner. A referee was appointed whose decisions were final.

When a big match was on, quite a large crowd of men eould be sen following the ampeting doges down the riverside. wery point being watehed with the keenest interest. It was quite as interest ing as Otter Hunting, to which, indeed, it bears a certain resem bance.

The dogs would assidnously hunt both banks of the river-which in this district ramies brom about twenty to forty yards in widthswimming from one bank to another as directed by their owners.

When one of the dogs made a "mark," both dogs were told to "stand back" and wait until a ferret was put into the hole or tree root to bolt the water rat. When the rat bolted, he usually made straight for the water, with the dogs in tull chase.

From the first dive the water rat would probably swim thirty or forty yards under water, and it was great fun to see the two

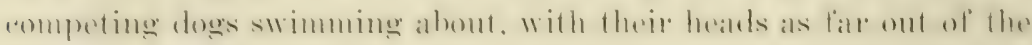
water as possible, watehing all round to see where the rat was com. ing up again.

When the water rat was viewed, each owner would shout to his dog and point to where the rat had been seen, and then there was a swimming race between the two dogs as to which could get up to the rat first.

The wily rat, as danger approached, dived under water again, to reappear some thirty or forty yards away, in some other diredom, when the dogs would swim alter him again. This was eontimed, time altere time. until the rat gratdually herame exhansted, when its dives gres shorter and shorter, with the result that one of the dogs would thish with a "kill," often judgring it so meatly that he womld dive clean under water for the rat and bring it up in his mouth.

As the dogs often made themselves very dirty with scratehing and tearing the earth from the rat holes on the river bank when 
they made " "mark," it was a common practice at that time to cut a separe piece of turf from a ficld and throw it into the river, and when it had sunk to the bottom the dogs were trained to dive in and fetch it out again, so that they would wash themselves cean before being taken home. I have seen many dogs do this half a dozen times in surecession.

'T'hese dogs were the constant companions of their masters and

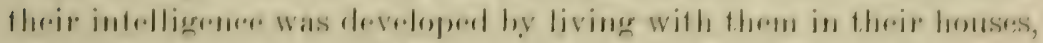
where they were treated like one of the family. Juring the day, when the men were at work, the dog would be lelt at home to proleet the wile and family. When the day's work was done, the mastre wombl put a formet in his porket and fake a walk up the rivere

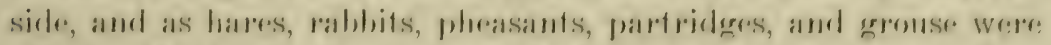
all plentiful in the distrobe as indreed threy alre at the presente day,

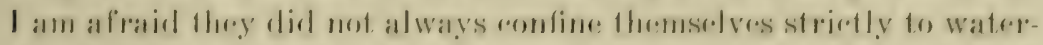

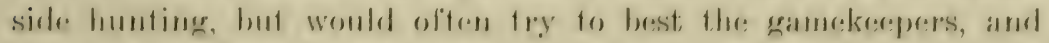

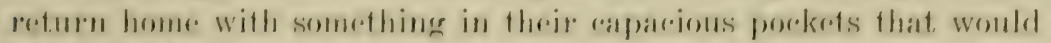
be useful for "the pot."

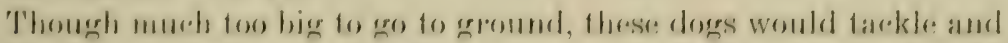

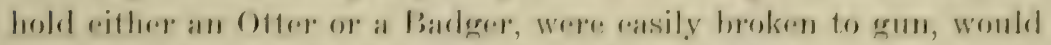

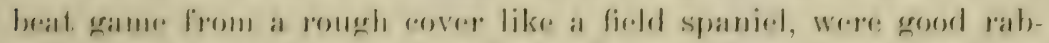
biters and would retrieve either fur or feather from either land of watrit.

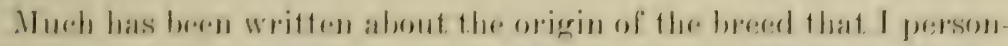
ally know to be quite incorrect, and in order to obtain really authente information on this important historial point, I resently

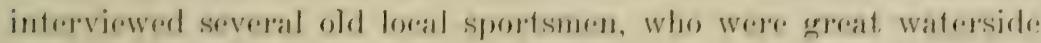
humters when I. was a boy.

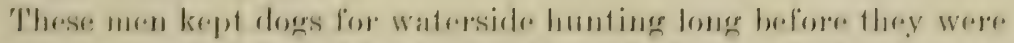

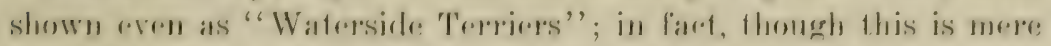

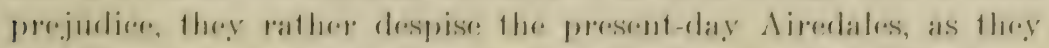
say they are not as game as they were in the old days. But they were all geroreally agreerl on ome proint, and that was that the Aire

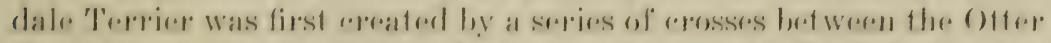

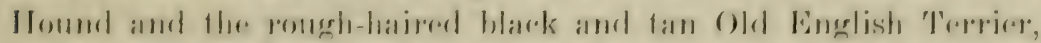

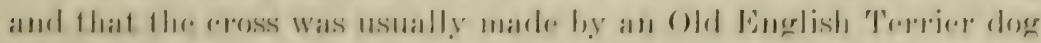

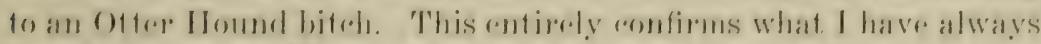
lieard before, and I believe it to be correct.

In confirmation of this, it is a fact that over forty years ago a

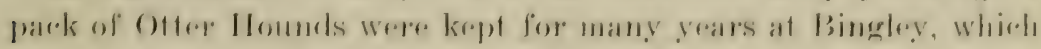




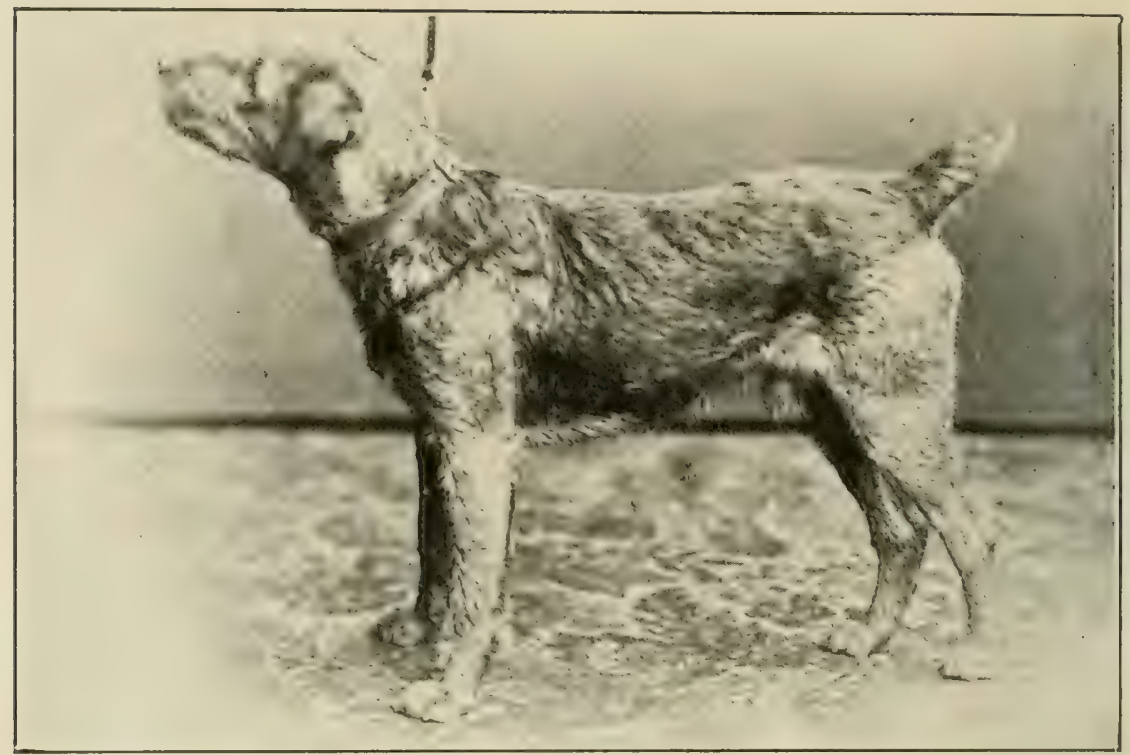

CII. CHOLMIONDELEY BRTAR

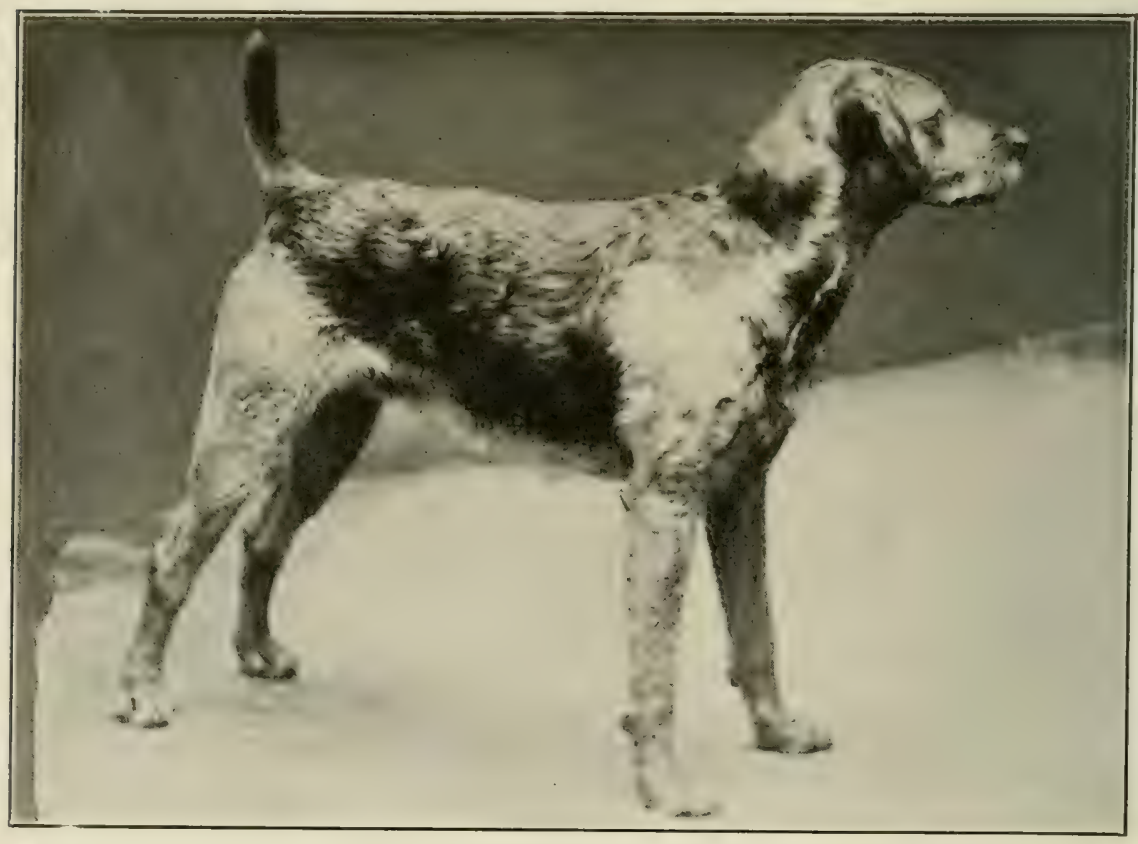

AIREDALE TERRY 
is in the heart of Airedale; and it is also a fact, that about the same period rough wire-haired black and tan Terriers, commonly called Old English Terriers, were very numerous in the district.

II f father kept these Old English Terriers and I remember them very well. In appearance they were somewhat similar to the modern Welsh Terrier, but much larger, weighing about 25 to 30 pounds. Judged by modern show standards, they would he considered coarse and cloddy all through. They were strong in skull, with deep, powerful jaws, plenty of bone and substance all through, with a good close, hard wiry coat, black on back and tan on head and legs, their general appearance giving one the impression of a game, sturdy, hardy 'Terrier.

These dogs were thorough vermin killers, good water dogs, and would fight till they were dead; and I must say that I have often thought it was a great pity that such a fine Old English Sporting Terrier should have been neglected, as it has been, and almost allowed to die out, though the modern Welsh Terrier is said to be descended from it.

These old English Terriers were originally used for waterside hunting, but they were somewhat deficient in nose and had not always the power necessary to cross the river at all points, as the river Aire runs very strongly in places.

So much money could be won in matches by a good waterside dog, that the waterside hunters cast about to find a dog with more scent and swimming power than the Old English Terrier, and a dog at the same time that must take naturally to water and to hunting. The Otter Hound was on the spot, and appeared to fulfil these requirements, and frequent crosses hetween the two were undoubtedly resorted to. The dogs resulting from the first cross were bred together again and again, as oceasion required, with frequent crosses hack to the Otter IIound or the Old English Terrier, until they gradually developed a new type of Terrier altogether, viz., a dog with the strength of scent, swimming power and hunting qualities of the Otter Hound, combined with the rermin-killing instinct and gameness of the Old English Terrier. I think that it is these very qualities which have made the Airedale Terrier such a great favorite with sportsmen in all parts of the world at the present day.

Classes were given for these dogs, who were then described as "Waterside Terriers," at a few local shows in the district, much in 
the same way that Border 'Terriers are now shown on the borlers of England and Scotland and in the English Lake District.

A few fanciers interested in the breed from a working point of view held a meeting at Bingley in 1879. When it was decided that in thature these dogs should be called diredale Terriel's, as the breed had been created in Airedale. Classes were provided for them under this name for the first time at the Airedale Igrieultural Show at Bingley, in August, 1879.

Soon afterwards classes were provided for them at Skipton, Bradford, Keighley and Otley ; the last named show, whith is the oldest Agrieultural show in England and held its one hundred and tenth consecutive show this year, always catered splendidly for the breed, and the gold medal given at this show for the best Airedale T'errier dog or hiteh was eonsidered for many rear's to be the blue ribhon of the hreed and drew exhibitors from all parts of Great Britain to compete for it.

The first prominent show diredales that I remember were Champion Bruce, ('hampion Wharfedale liush, Mrr. IIorsfall's Trimmer, and Carr's C'rack, owned by Mr. Tom C'arr of keighley. These were all hig, strong dogs, and showed distinct traes of their Otter Hound ancestry, particularly in ears, coat and bone.

Ir. Tatham of Rochdale hat a very strong kemnel of the breed for sereral years, and was a most successful exhibitor. his best dog perhaps being Champion Newhould Test. IIis entire kennel passed into the possession of Mr. II. M. Bryans, whose dogs, owning the prefare of "Cholmondeley," were afterwards destined to make history in the breed and to this gentleman must be given the eredit of doing great service to the breed, as he was always prepared to give a good price for a good dog and bred a lot of good ones himself.

Mr. Alexander Walker of Bradford was also a most successful "xhibitor for many years in the early days of the hreed, his bitch Champion Vixen III being quite the best of her day, with a coat like wire and she is still considered hy many old Airedale men to be one of the best bitches ever shown.

Another Bradford man, Mr. F. Bairstow, whose dogs owned the prefix of "Rustie." was also a leading hreeder and exhihitor for many years; his hest dogs. I think, were Rustic Twig. Rustic Lald and Champion Riustic Kitty.

Mr. Maude Barret of Otley was the backbone of the breed in Yorkshire for many years. until his sudden death when in the very 


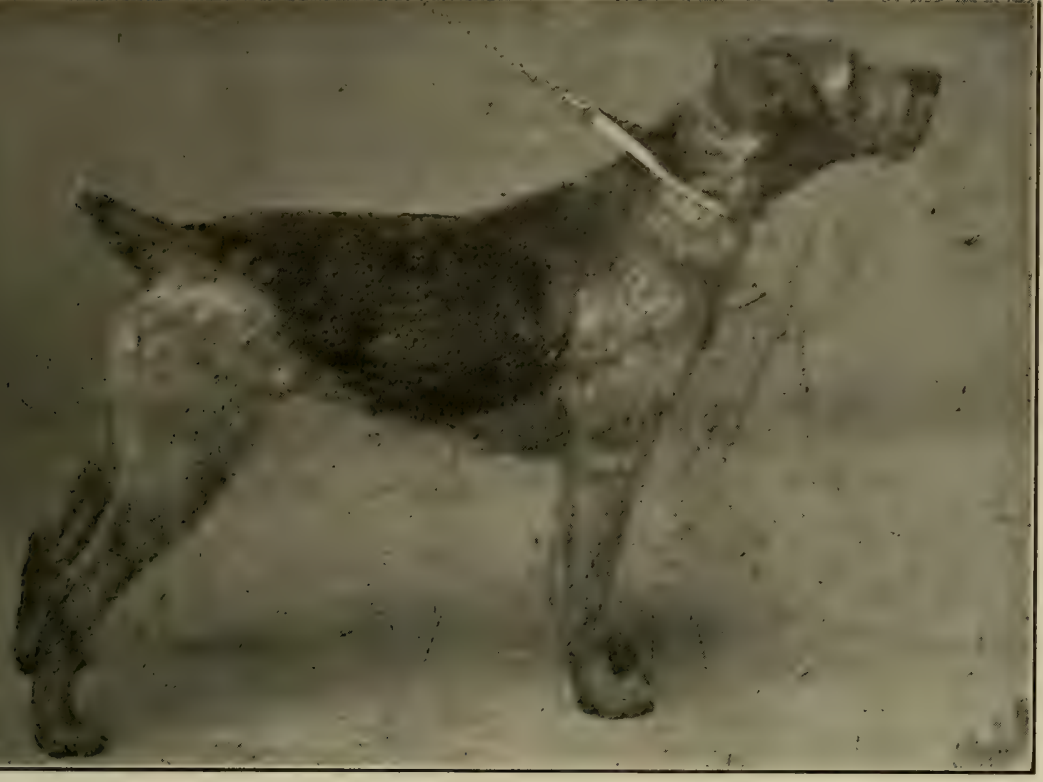

CH. DUMBARTON LASS

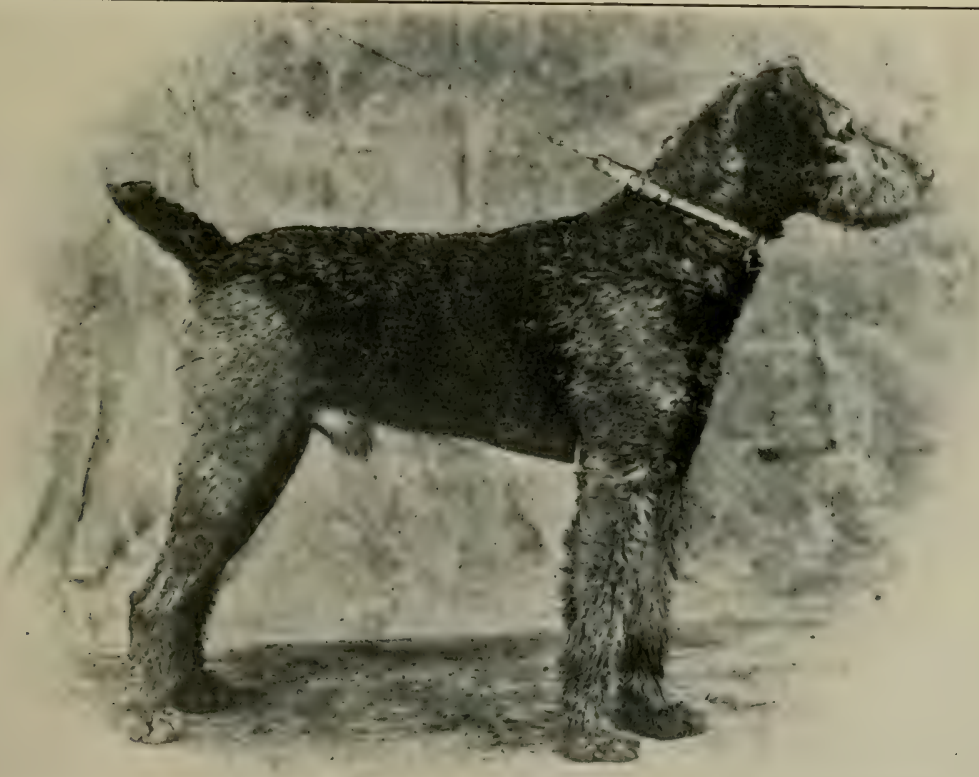

CH. MASTER BRIAR 
prime of life. He was a true sportsman and one of nature's gentlemen, and his death was not only a great loss to the breed, but also a terrible shock to his wide circle of friends. He was on the Committee of the Otley Show and was largely instrumental in providing the splendid "lassification that was given for Airedales in his native town for many years, which was the reason of his show being recognized generally, at one time, as being the best and most representative show of Airedales in England.

He had one of the strongest kemnels of his day, his best dogs, perhaps, being Champion Tommy Tucker and Champion Otley Chevin.

Mrr. H. MI. Biryans at this period began to buy largely, the cream of his purchases being ('hampion ('holmondeley Briar, from whom, as I will show presently, nearly all the best show Airedales of the present day are directly descended.

This dog was the undisputed ('hampion of the hreed for many years, and I think I an "orrert in saying that he was only beaten twire and then only when he had passed his prime. The first time was at Jingley, when he was beaten hy Mr. Maude Barret's Champion Tommy Turker. This was a most unpopular decision with the "rowd at the ringside, and I must say" that I know no crowd of spectators who are keener or more outspoken critics than the Bingley ringsiders were in the old days, when nearly every man present knew all the points of the hreed. The second time he was beaten was at Manchester hy Mr. IIolland Buckley's Champion Clonmel Iarvel, a revdict that was generally endorsed, as youth must be served and the old dog had seen his best day.

('hampion Cholmondeley Briar was bred at Queenshury near Bradford, and he was first exhibited at some small local show under the name of Red Robin. He was quickly spotted by the astute Mr. Sam Wilson, who, being always on the lookout for a "lucky packet," as he called them, soon became his fortunate owner.

I well remember going to his house one Sunday morning to see a dog that he was going to show for me at the Crystal Palace, when he told me that he had just hought a young Airedale that was a world beater. I had heard Master Sam talk about "world heaters" before, and was somewhat sceptical, but when he brought him out I fell in love with him on the spot, and as he afterwards proved to be one of the pillars of the Stud Book. I will endeavor to deseribe him as I saw him that day. 
He was then about eleven months old, and not quite fully furnished, but was a remarkably well developed dog for his age. He had a beautiful long, clean, typical head, with great power in front of the eyes, nice small ears, lovely neck, and clean, well placed shoulders, with good short, firm back and well set, gaily carried tail. His bone and legs and feet were extraordinary, and as round and firm as an English Foxhound, and being well covered with hair, gave him an appearance of immense strength. In color he was a dense black on his back and a rich golden tan on his legs and quarters, and his coat was both straight and hard. He had any amount of substance, yet he was all Terrier, with nothing houndy or coarse about him. He was quite up to the standard weight, and when he was fully furnished I should say he was a little over.

The photograph of Ch. Cholmondeley Briar which is published in this book was taken when he was past his prime, and really gives very little idea of what he was like, but it is the only one I have ever seen of him.

Champion Cholmondeley Briar will always be remembered by Airedale Terrier breeders, as his name appears in nearly every firstclass pedigree of the present day, if it is only traced far enough hack, and he stamped his own grand type and character upon his breed in a most remarkable manner.

His sire was a dog named Airedale Jerry, whom I remember well; he was a dog who did a lot of winning in the north of England, but was never quite up to Championship form. He was a big, strong-boned dog with a long, typical head and a real hard, wiry coat, but was overdone in ears. He was owned by Mr. John G. Iorrocks, who, although he does not exhibit much now, is still one of the best and most popular judges of the breed. The sire of Airedale Jerry was a dog named Rattler, who won many prizes, and his dam, Bess, was by Champion Brush, who was hy Champion Bruce, so that his pedigree goes back to the very first dogs that were exhibited.

The dam of Champion Cholmondeley Briar was a bitch named Luce, who was afterwards purehased by Mr. Bryans and re-named Cholmondeley Luce, and appears under this name in many pedigrees. I never saw her myself, but people who knew her well have told me that she was a good-headed bitch, very terrier-like in character, with small ears and a good coat, but on the small side. It is impossible to follow out the pedigrees of all the dogs sired by Cham- 
pion Cholmondeley Briar, so I will take the progeny of only one of his sons-viz., Briar Test-as a typical example.

Briar Test was by Champion Cholmondeley Briar ex Rosamund by Mr. Tatham's Champion Newbould Test. He proved to he a most sureessful stud dog, and was a winner in good company. He inherited his sire's wonderful bone, legs and feet, and had a straight, hard dense coat, with black saddle and rich tan. and was a sturdy, well built Terrier all through, just lacking quality in head, which always kept him back in the keenest competition.

Briar Test, mated to Betty lyy Mr. Maude Barret's A. P. Bruce, - a lovely quality terrier with beautiful coat and color,--sired in his turn Champion Master Briar, one of the hest-headed Airedales ever bred. He was a dog brimful of true Airedale type and character, and was essentially a "laster," as his head was as "lean as a puppy when I last saw him, when he was eight years old. IIe did an immense amount of good to the breed, as he stamped his own beautiful type and lasting qualities on his progeny.

Champion Master Briar. in his turn, sired Messes. Mills and Buckley's Champion Clonmel Monarch, who will always remain in my memory as one of the best I have seen. I judged him at Otley when he was a puppy about eleren months old, and gave him all I could, including the coveted gold medal for the best Airedale in the show, and I don't think he was ever beaten in England afterwards. He was a dog well up to the standard weight, yet full of quality and Terrier character, with a long typical head. lovely shoulders, great bone, nice level top, with great style and a good mover. He was a blue grizzle in color, which is not the color I like best, as I prefer the old-fashioned hlack saddle with the rich golden tan; but a good Terrier, like a good horse, is never a had color, and a blue grizzle is, after all, a good Airedale color, though the coat is not usually as straight or as good in texture as the black and tan. Although only at stud in England for a very short period. Champion Clommel Monareh left a lot of good stock behind him, as he was sire of Champion Tone Regent, Ch. Broadlands Royal Descendant, Ch. Clommel Bed Rock, and a lot of bitches who produced good ones afterwards, and it was a distinct loss to the breed in England when he was sold to go to America, though he has done much good for the breed over there.

To continue the male line, Champion Clonmel Monarch sired Clonmel Chilperie, who, when mated to Clonmel Loyal (a grand- 
daughter of (hampion Master Briar), sired Champion Master Royal, a rery high quality Terrier who went to America. Champion Master Royal, in his turn, when mated to Madame Briar (another daughter of Ch. Master Briar), sired Champion Midland Royal, who is the sire of Rockley Vesta, the dam of Champion Rockley Oorang, who is so well known both as a show dog and a stud dog at the present time.

Another son of Champion Master Briar who proved a most successful stud dog, and from whom many of the present-day Champions trace their descent, was a most beautiful Terrier named Crompton Marvel. He was a Terrier that I always thought was very unlucky never to become a full Champion, as he was full of quality, with beautiful coat and color. He was sire to Champion Freeman Terror, who is now in America, but he will be remembered chiefly by Airedale breeders as being the sire (when mated to Abbey Princess by (h. Clommel Monarch) of the great show and stud dog

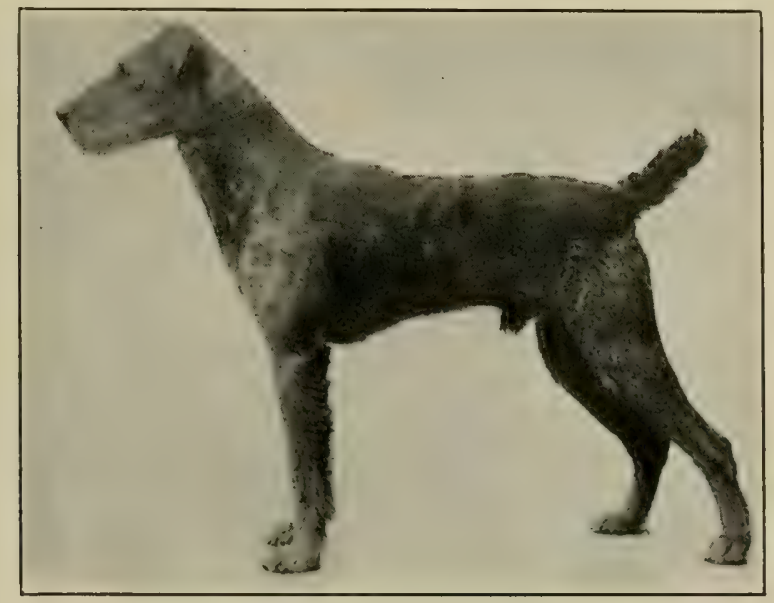

CH. TINTERN ROYALIST

Champion Crompton Oorang, who is sire and grandsire to more Champions and first-class show dogs than any Airedale Terrier living at the present day.

Champion Crompton Oorang was first brought out under me at Otley, when he was about eight months old, and although he was somewhat small for his age, he was such a beautiful type and so full 
of Airedale character that I put him first in all the Junior Classes. For some time after this show, it appears that he hardly grew at all, and his owners, thinking that he would never grow big enough, sold him for a sum that I have not the least doubt he has earned at stud in a month many times since for his lucky owner, Mr. Wr. Proudlove.

Champion C'rompton Oorang in his turn (when mated to Redeap Musie by ('h. Master Briar) sired Champion Crompton Performer, a rare good Terrier, who is grandsire to Champion Illuminator, who has recently gone over to America.

Champion Crompton Oorang is also the sire of the English and American Champion, Danny Graig Commander, known in America as Prince of York. He is also the sire of Champion Rockley Oorang, whose pedigree has already been traced on his dam's side.

To continue this line again on the male side, Champion Rockley Oorang is the sire of Champion King Oorang and (mated to Horfield Thistle by (h. Rork King hy (h. Master Briar) he is also the sire of the latest English Champion, Flornell Oorang, thus showing the umbroken descent of the best show dogs of the present day from the first Champions of the breed.

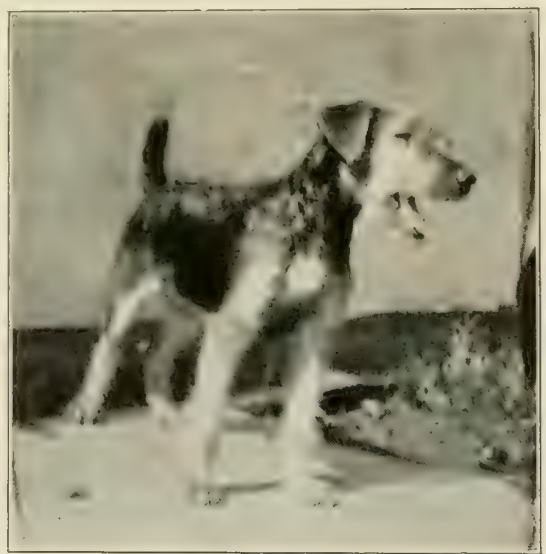

BOTHWELL SORCERESS

AT 3 MONTHS

Winner of Best in Show, Hedgeley Puppy Show, 1911

Then Orwned by A. B. Proctor 



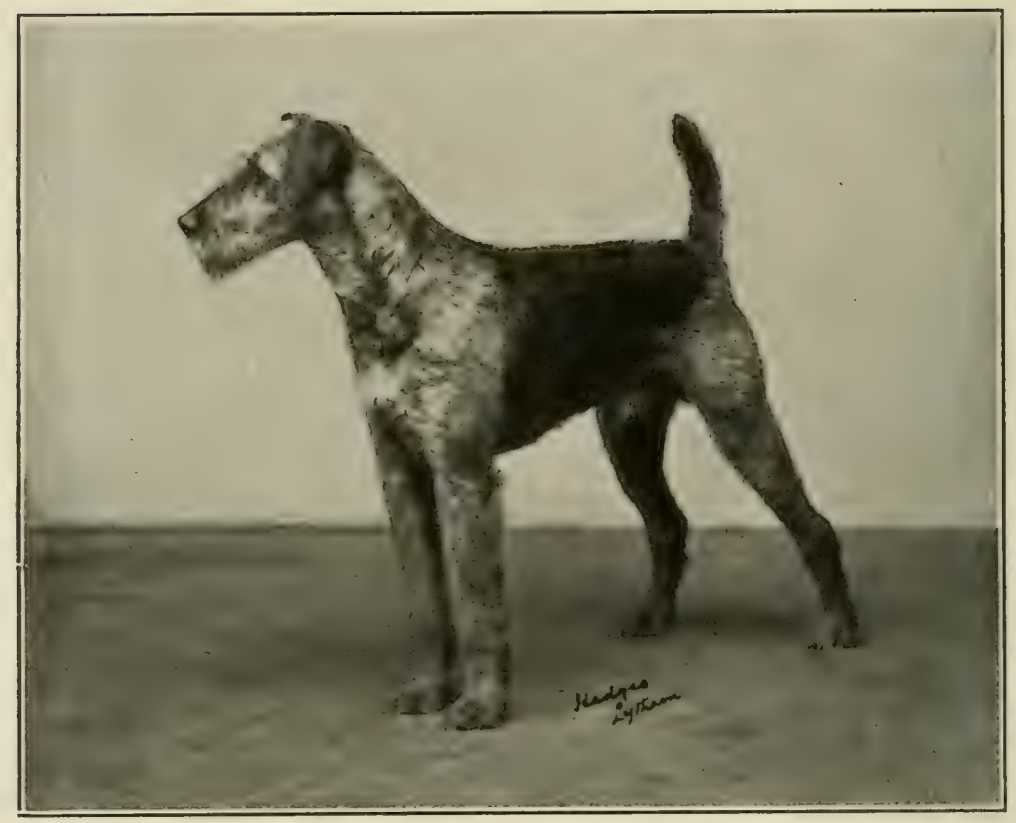

DARGLE DECLARE

Tintern Desire ex Victoria Madge 
CHAPTER II

RECENT HISTORY

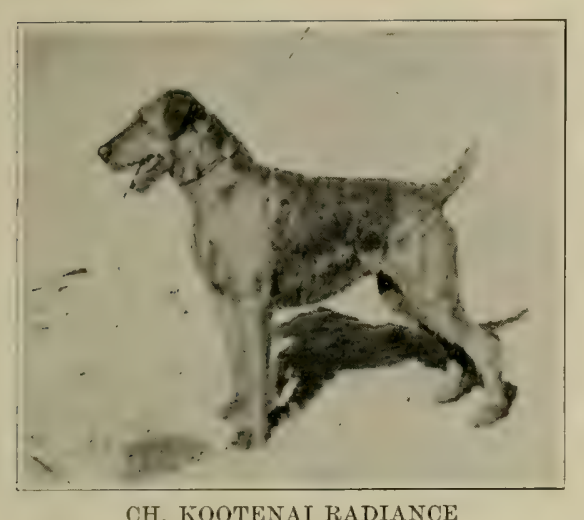

CH. KOOTENAY RADIANCE

Coming to what we may term the intermediate period of the breed, the most prominent breeders and exhibitors that I remember -though doubtless I have overlooked many that have a right to be mentoned here-in the North of England were Mr. J. R. Cooper, who owned Champion Rock King, Champion Rock Salt and Champion Rock Princess; the latter, a very beautiful bitch, was purchased by Mr. Foxhall Rene, but died on her way to America. Mr. A. E. Jennings was also a very suecessful exhibitor, and owned two leaders of the breed in Champion Master Briar, whose name occurs in nearly every first-class perigree, and Champion Dumbarton Lass, a very beautiful bitch, who was purchased by Mr. Jos. A. Lauri of Montreal, and was, I believe, a big winner in America.

When Mr. Jennings' kennel was sold, the majority of his dogs were purchased by $\mathrm{M}$ [r. Stuart Noble, who had a meteoric career for a short time. Mr. John G. IIorrocks, the Abbott Bros., and the Lever Bros. were all keen breeders and exhibitors, and the prefix of "Crompton" owned by the latter firm will be found in the peigreen of the hest Airedales of the present day. Mr. W. H. Chandler was also a keen breeder, and his dogs, with their prefix of "Primrose," are still well in front at the present day.

I Ir. Tho. Kershaw of Bradford always had some good ones, and has handled some of the best of the breed at different times, amongst them being Champion Dumbarton Sceptre, who will always live in

17 


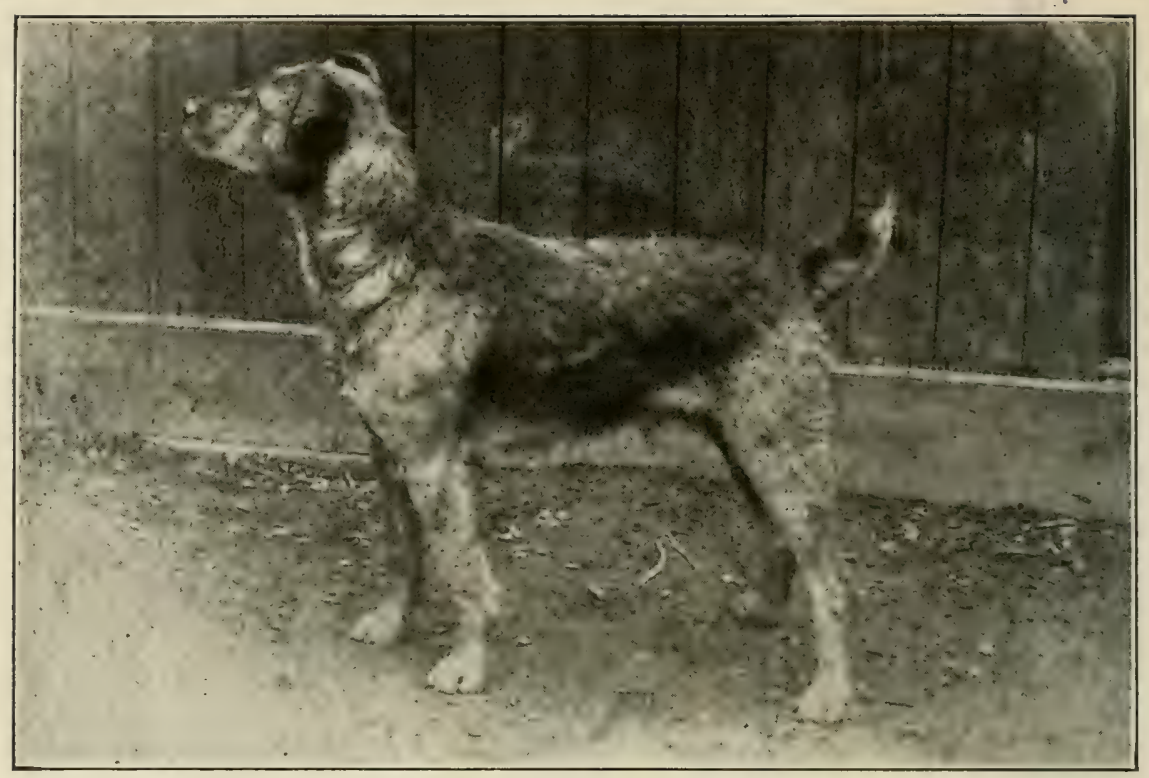

STUDHOLME SNOWBALL

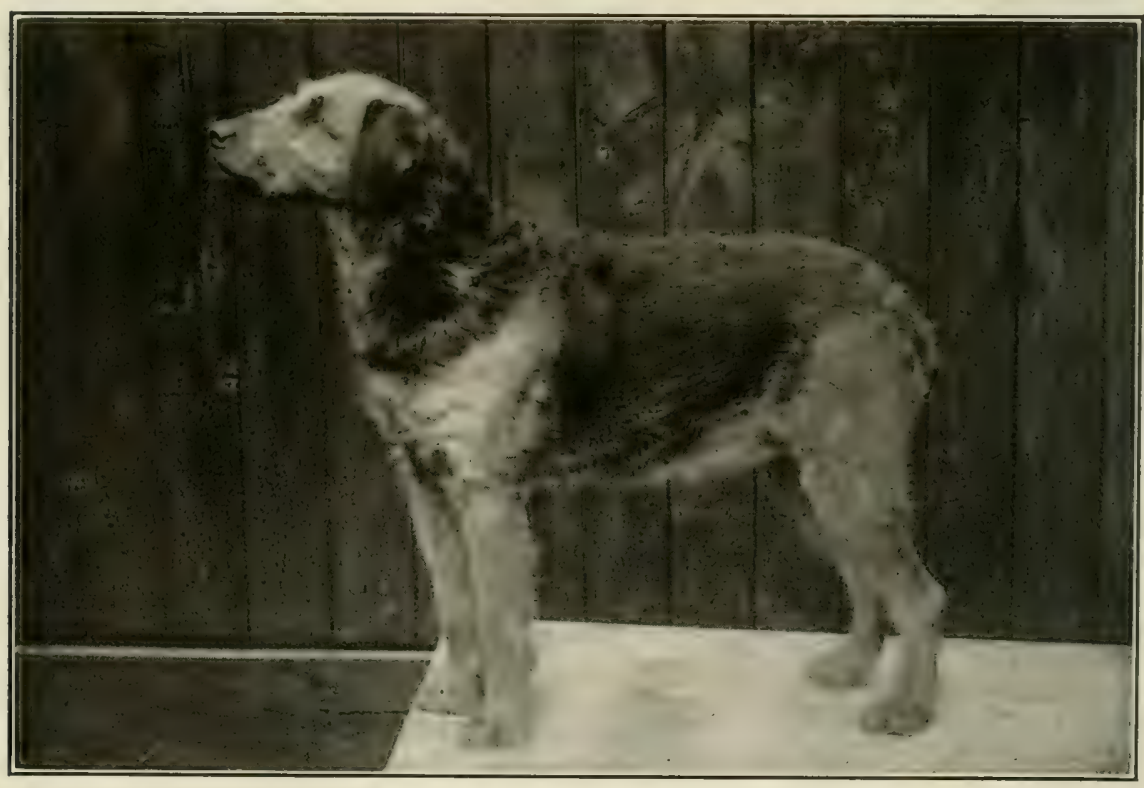

GIL'TRAP

A Famous Brood Biteh 
my memory as being one of the best and most typical Airedale Terrier bitches that I have seen. She was purchased by Mr. Theo. Offerman of New York, and I have no doubt many American fanciers will remember her.

Mr. Fmil Sachse of Shipley was also a most successful breeder and exhibitor at this period. Any fanciers who have any of his "Studholme" blood in their kennels may be sure that they come from a very good and most earefully bred strain. So, likewise, was Mr. Herbert Croft of Bradford, whose dogs, with the prefix of "Barkerend," were generally to the front. These were among the keenest of the Yorkshire exhibitors.

In the Midlands, also, the breed became very popular. Mr. L. H. Baker and Mr. E. Blunt being enthusiastic supporters of the breed. The latter gentleman was for several years Hon. See. to the Airedale Terrier Club, and owned some very good Terriers; the best of his early ones, perhaps, were Lord Belper and Princess Nut, who both went to America.

Although Yorkshiremen must be given the credit of creating the Airedale Terrier, sportsmen in other parts of the country, and particularly in the South and West of England, were quick to notice its value and possibilities.

One of the first in the South of England to take up the breed was Mr. Holland Buckley, whose kennel prefix of "Clonmel" is now known wherever Airedales are kept and shown; and it is only fair to state that this gentleman, along with his partner, Mr. E. Royston Mills, has probably done more to foster and encourage the breed than any other breeder of the present day. Mr. Marshall Lee was the owner of that beautiful bitch Champion Walton Victory; Mr. Hunter Johnstone will always be remembered by Airedale Terrier fanciers as the owner of Briarwood, the best ten months old puppy I ever saw-but, alas! he grew too coarse with age, though he proved an excellent stud dog; Mr. Clarkson was the owner of Champion Broadlands Bashful and Champion Broadlands Royal Descendant; Mr. Baines Condy has owned some good ones in his time, including Ch. Huckleberry Lass; Mr. E. R. L. Hoskins was the owner of Briarean Sultan and Champion Legrams Princess, to mention only two of the many good ones that he owned; and MIr. G. H. Elder of Taunton's dogs with the prefix of "Tone" were always in front. II Champion Tone Masterpiece stands out in my memory as a very beautiful Terrier, but just on the small side. 


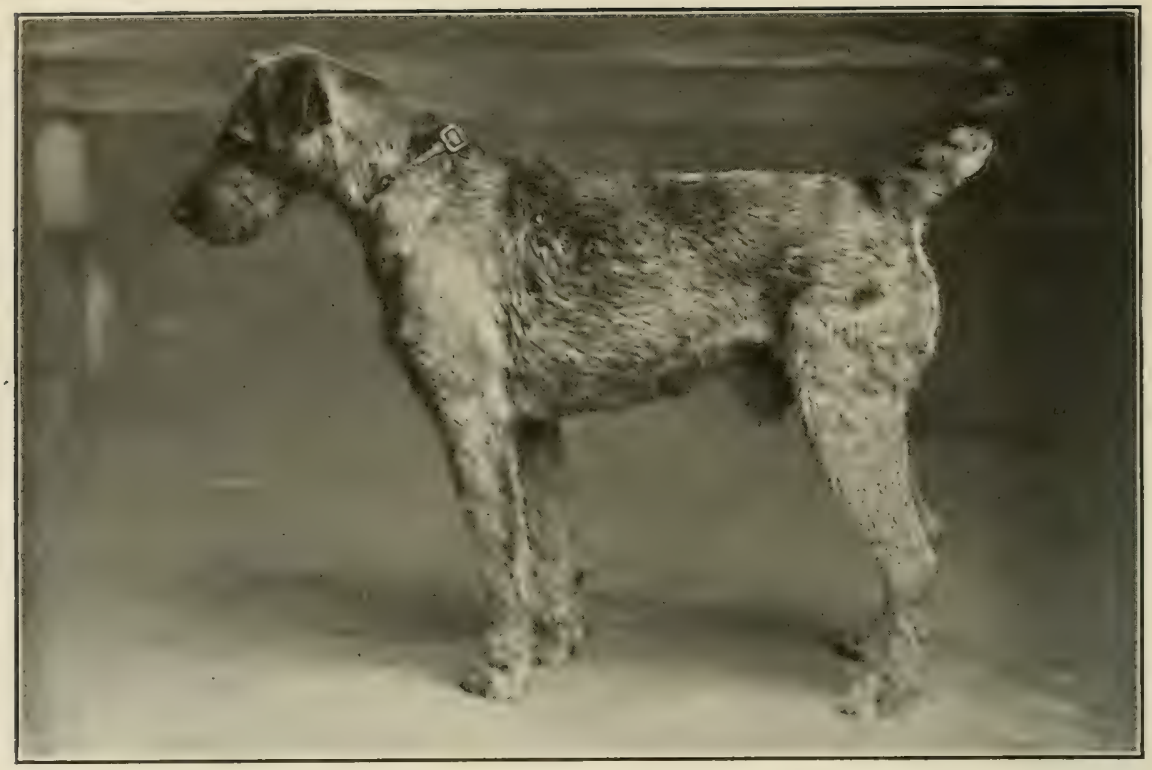

BRIARWOOD

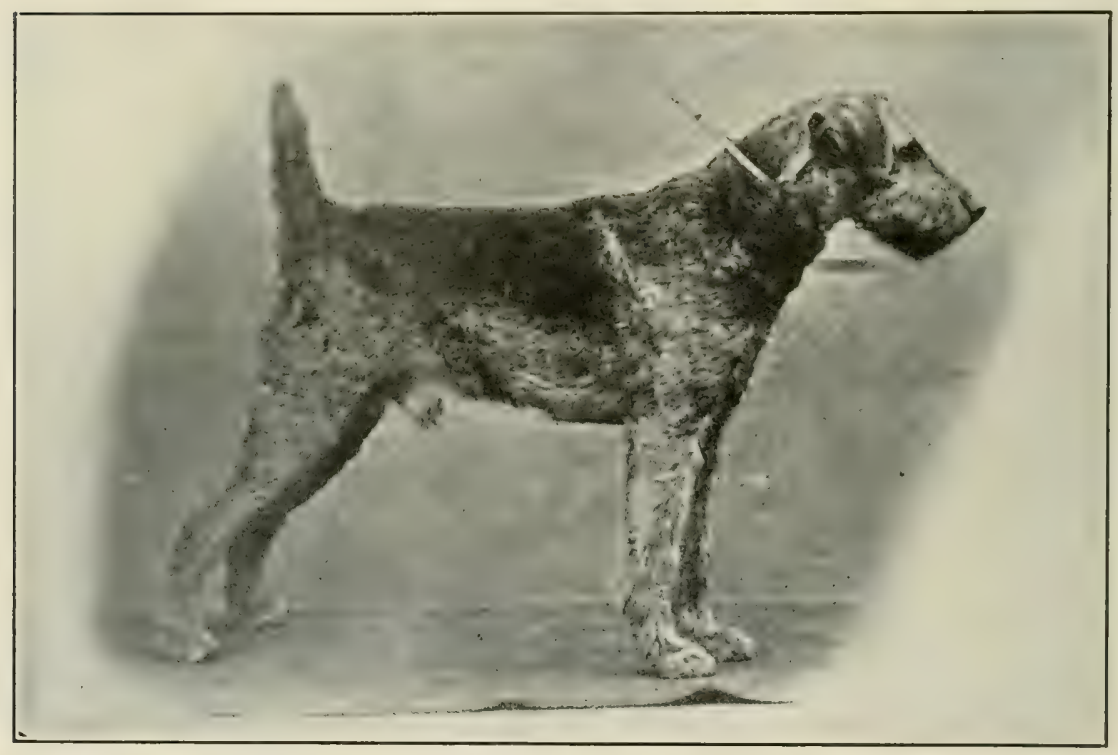

CROMPTON MARVEL 
He was purchased by Mr. Theo. Offerman of New York, and proved to be a "laster" like his father, Champion Master Briar, as he was as good as ever when I judged him at Boston, Mass., in 1905. These gentlemen, and others whose names I cannot remember now, all rendered yeoman service to the breed, and have helped to lay a firm foundation for present-day breeders.

Many Clubs were formed for the encouragement and advancement of the breed, the chief of these being The Airedale Terrier Club, the North of England Airedale Terrier ('lub, the Midland Airedale Terrier Club, and the London and South of England Airedale Terrier Club.

During the lifetime of Maude Barret the Otley Show was generally recognized as being the hest show of Airedale Terriers in England, as they always gave a splendid classification; and being held in the first week in May, it was the first of the outdoor summer shows, and if a puppy could win at otley it was usually a very good start for the rest of the summer shows. Since Mr. Maude Barret's death, the classification has fallen oft, and the best show of Airedales at the present day-although as a Yorkshireman I am naturally loath to admit it-is generally recognized as being the Annual Club) Show of the South of England Airedale Terrier ('luh), which is held in ronnertion with the Great Joint Terrier show at the Botanical Gardens, London.

It is a well known axiom amongst dog exhibitors that nothing creates a good entry like a good classification, and in Mr. Holland Buckley, the Hon. Secretary of the Club and Nanager of the Show, the Club have a past master in the art of show management, with the result that a huge classification is always given, which attracts entries from all parts of the country. When I had the howor of judging this Show, last year, there were twenty-five classes given for Airedale T'erriers, with twenty special prizes, mostly cash and silver ("ups, and two Championships on offer, one for each sex.

The Show is held in the early part of .June, in the height of the London season, at a time of the year when London is full of visitors; and the Botanical Cardens, with their well kept, velvety lawns, beautiful flower heds, and shady trees, make an ideal place for an outdoor summer show. This beautiful show ground, together with the gaily dressed. fashionable crowd of exhibitors and spectators, appears to be an increasing attraction, not only to British exhibitors, who go up for the Show and a few days' holiday in town, but 
for doggy people from all parts of the world, Americans heing usually very well represented.

The Yorkshire working men, who originally bred and kept the Airedale Terrier solely for its working qualities and gameness, little dreamt, at the time, that they were creating a Terrier that would become, within their own lifetime, one of the most popular Terriers in the world, and which would command prices as high as, it not higher than, any other breed of Terrier. $\mathfrak{t}+00$ is said to have been given for one Airedale that went to America last year, and $\mathfrak{f}^{\prime} 300$ for another, and I could name over twenty Airedale Terrier's that changed hands at prices between $₫ 100$ and $£ 200$ within the last few years.

It is the working qualities of the Aireclale that have made it so popular in all parts of the world; and if these qualities are only maintained, I feel sure there is an even brighter future for the breed, which has been esperially fortmate in having an euthusiastic body of fanciers behind it, who have pushed it and boomed it at every possible opportunity.

Thinking over the Airedales that I have known for the last thirty years, I fancy there may have been two or three dogs of outstanding merit in the past that would perhaps bear comparison with the dogs of the present day ; but in the old days these stood clean away from all the rest, and it was easy judging. At the present day it is the exreption to see a really bad one at a good show, and classes naturally take a great deal more judging, and require much keener and intelligent criticism, when there may he five or six Champions, all near together, in one class, than they did in the old days, when there were just one or two good ones that stood out by themselves.

The first Airedale Terriers that were exhibited showed distinct traces of their Otter Hound ancestry, and were a great contrast to the hest show dogs of the present day, who combine the bone, strength and substance of the Otter Hound with the smart, cleancut outline and quality of a high-class Terrier; and when we take into consideration the fact that it is only just over thirty years since the first classes were provided for Airedale Terriers at Bingley, the greatest possible credit must be given to Airedale Terrier breeders for producing such a beautiful Terrier in such a comparatively short time. 



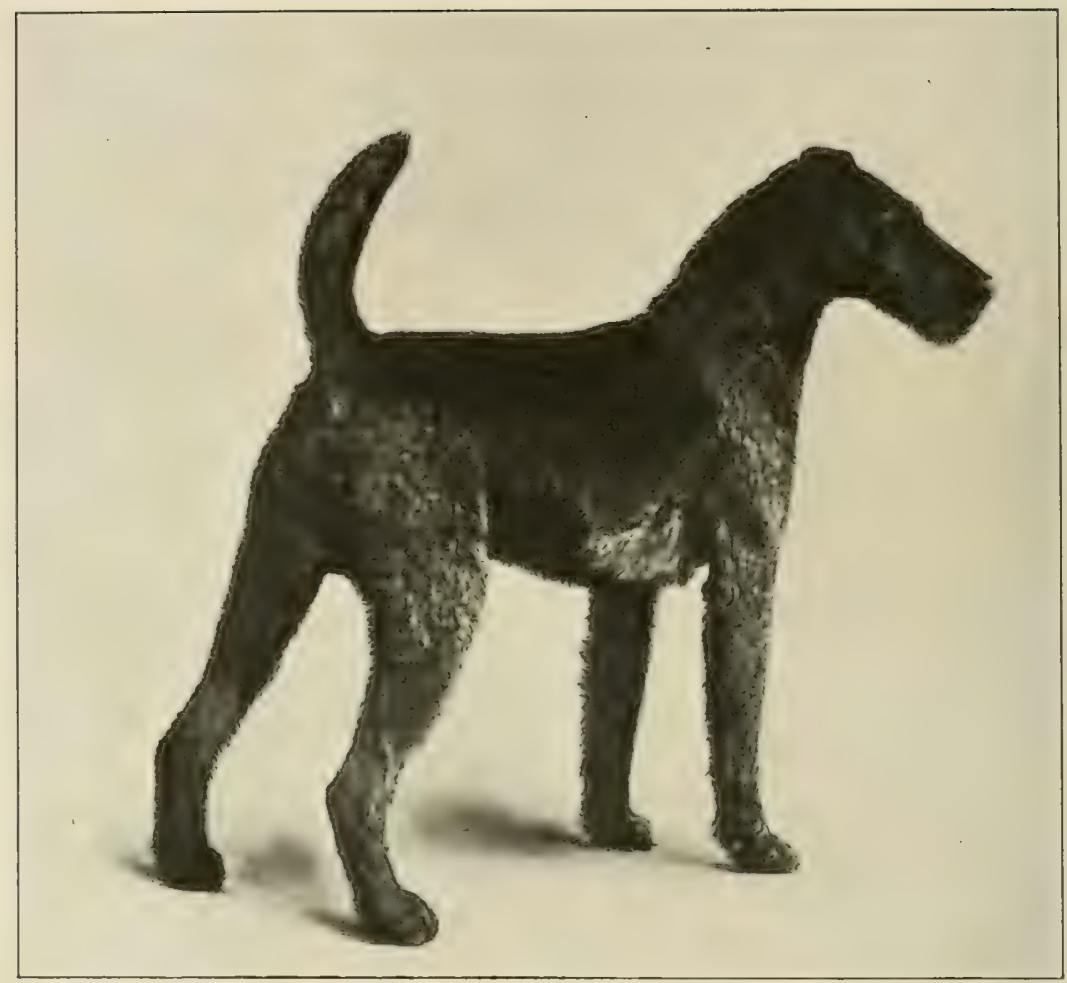

CH, SOUDAN SWIVELLER

(Gaelic Hussar)

A. K. C. S. B. 150891

Whelped March 21, 1910

By Elruge Monarch ex Gaelic Beauty

Owned by Wm. Prescott Wolcott 


\section{CHAPTER III}

\section{HOW TO BREED WINNERS}

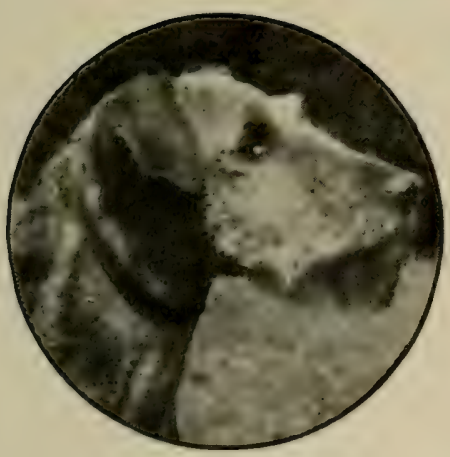

('H. PRINCE OF' YORK

IT is an easy matter for a rich man to write out a cheque and buy the very best dogs of any breed, but unfortunately all fanciers are not in that happy position, and if they want to possess good ones they must breed them.

A real fancier, whether he be a rich man or a poor man, is a breeder at heart, and loves his dog for itself alone, and not for its monetary value. He derives a lot of real pleasure from devoting his leisure moments to the study and breeding of his favorite breed of $\mathrm{dog}$; and if he buys the right kind of breeding stock to begin with, it can be made a very profitable hobby as well. There are hundreds of people in England who make a good living by breeding high-class show dogs, and I know plenty of good business men who pay their rent and rates and get a good summer holiday out of breeding show dogs. I must say that I know no hobby from which a business man can get more pleasure, if he is huilt that way, as it takes him out into the fresh air, and causes him to walk miles with his dogs that he would never do otherwise.

If he is a true fancier, and has got the right kind of grit in him. although his efforts are not crowned with success all at once, he will gamely struggle on, learning something from every failure, and his triumph is all the greater when at last he has the glory of breeding a Champion, and all the best men in the fancy are bidding against one another to get possession of it.

The first thing I would recommend the budding $\Lambda$ iredale Terrier fancier to do, is to get the ideal Aireclale Terrier firmly fixed in his mind's eye, ly taking every possible opportunity of going to the best 


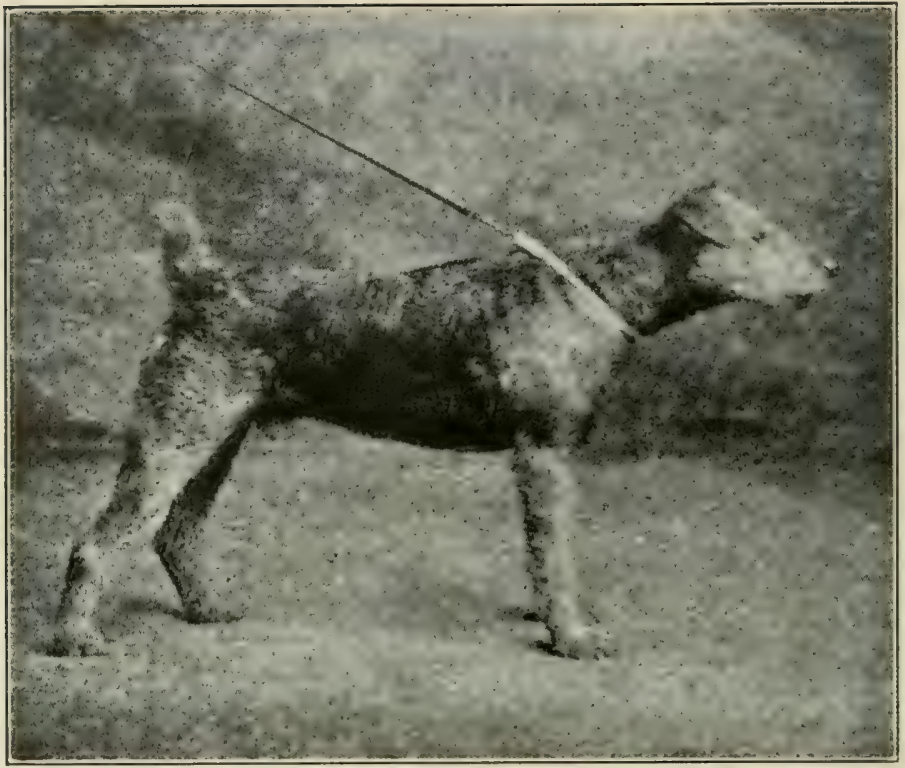

CH. YORK MASTERPIECE

(Ch. Tone Masterpiece)

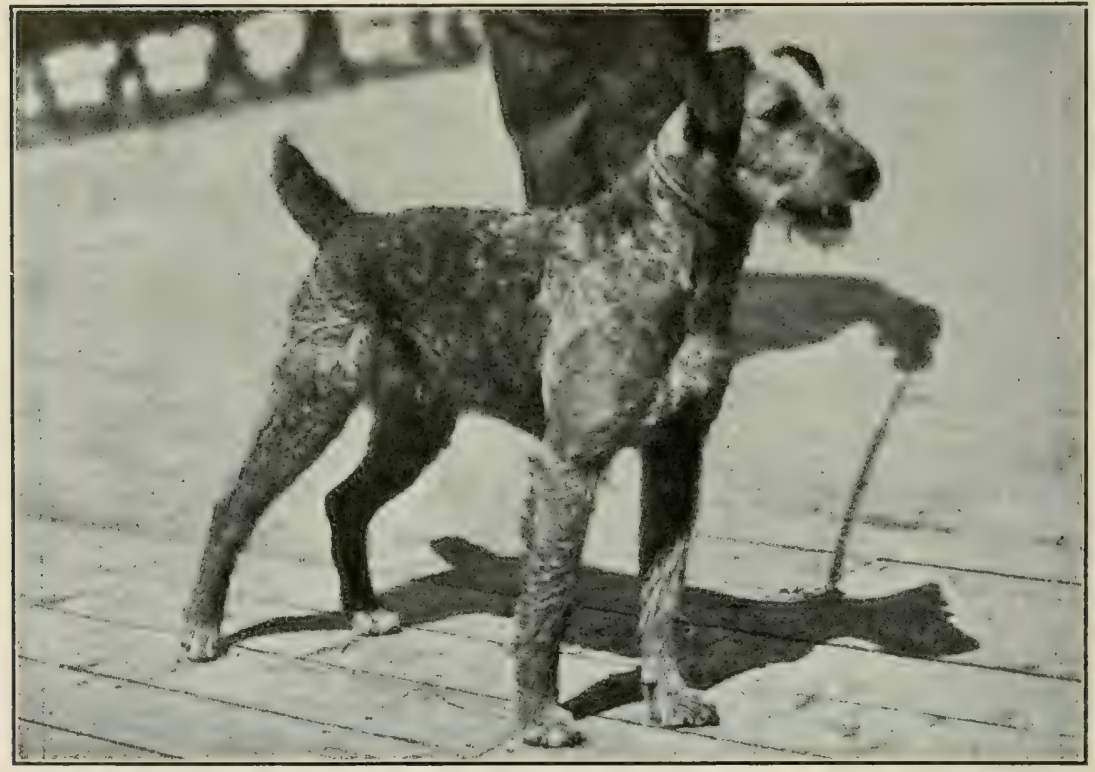

CH. YORK SCEPTRE

(Ch. Dumbarton Sceptre) 
shows and seeing the best show dogs of the day. In my younger days I spent my holidays in going to the best shows in Great Britain and Ireland, and to the personal knowledge $\mathrm{I}$ acquired of all the best show dogs of those days, I feel certain that I owe whatever success I have since had as a breeder.

I don't suppose there ever was a really perfect dog of any breed, -at all events, it has never been my good fortune to see one,-but by comparing the best points in the best dogs, the novice will gradually get a good idea of what a really perfect Airedale Terrier should be like.

I would also strongly recommend the novice to see the dogs judged in the show ring, as it is impossible to get a correct idea of what a dog is really like by seeing him on the show bench only. A dog with a good head and ears and a long, slack body and weak hind quarters often looks better on the show bench than a dog who may not be quite so good in head, but who smothers the other dog in body properties.

Having got the ideal Airedale Terrier firmly fixed in his mind's eye, the next step for the intending breeder is the selection of the brood bitch. This is a most important thing, and is worthy of the most careful consideration, as one good bitch, properly mated, may keep a breeder in front for years. It is quality, not quantity, that is wanted in breeding show dogs. Though very few people seem to realize it, a good brood bitch, if she happens to be mated right, can earn more money than a good stud dog. A bitch that produces first-elass show dogs, year after year, is a little gold-mine to her owner, and I know several bitches whose progeny have realized hundreds of pounds, besides keeping their fortunate owners in the front rank of exhibitors for years.

$A$ bitch bred from a family that has consistently produced firstclass show dogs, from one generation to another, is invaluable. The best are by far the cheapest in the end. It is no use wasting time "trying to breed rats from mice," as we say in Yorkshire-life is too short.

$\Lambda$ good brood bitch need not necessarily be a good show bitch; in fact, I think more good winners have been bred from the sisters to Champion bitches, than from Champions themselves. There are two things I consider absolutely essential to a brood bitch, and they are first-class breeding and a sound, healthy constitution.

It is impossible to overrate the importance of first-class breeding. 
By this I mean a pedigree of at least three generations on both sides, every individual member of which was either a first-class show specimen, a first-class stud dog, or a first-class brood bitch. If they can be procured with these characteristics for a longer period, so much the better. Dogs and bitches bred from such a family possess the power to reproduce themselves in a very marked degree.

I would certainly prefer to breed from a moderate-looking bitch bred from a first-class family, if she had no really bad faults, than I would from a common-bred bitch, no matter how good-looking she was herself.

A sound, healthy constitution is also a most important thing in a hrood biteh. A strong, healthy bitch is far likelier to produce winners than a bitch-no matter what show qualifications she may possess - that is unhealthy, and a bad doer, and has to be conditioned to get her into show form. Puppies hred from the former are not half the trouble to rear, as she will give them plenty of good, wholesome milk; they will thrive on it, and will eat any kind of plain, wholesome food afterwards. 'The latter' seldom las much milk, and what milk she has is generally unwholesome, and her puppies lack vitality, are generally unhealthy and seldom grow into anything good.

Somnd, healthy dogs are no trouble either to rear or to get ready to show. as they will eat practically anything, and any sportsman knows which is the best kind for work. A good doer comes home after a hard day's work and will eat a hearty meal, and go off to sleep, and be merry and hright next morning, and ready for another day's sport. A had doer will turn away from good, wholesome food, and is little use for work the next day.

It is the same with show dogs. A good-constitutioned dog can stand travelling about from show to show, as it will eat and sleepl whenever it gets a chance; but bad doers, who have had to be drugered to get them into show rondition, cannot stand the strain, and are soon out of condition again.

A bitch selected for breeding should be well balanced all over, and if she has no really excellent qualities, should have no really bad faults. The points that I consider essential are a nice, wellbalanced head, small ears, good bone and legs and feet. and a srmmetrical body. A good coat is not really an essential if the bitch has an exceptionally long head and is bred from a long-headed family, as this can be corrected by proper mating. 'The coat I like 


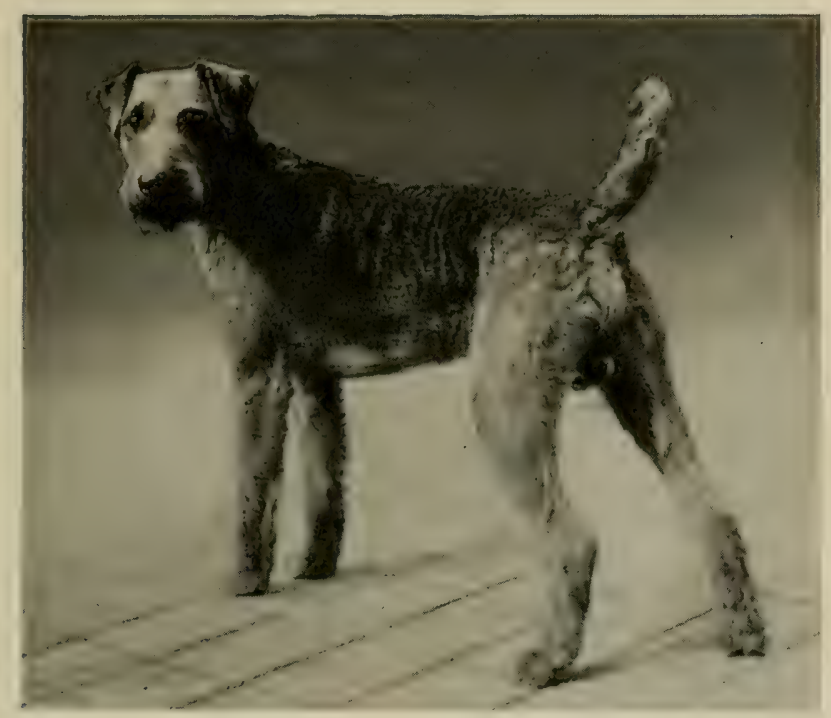

CH. SOUDAN STAMBOUT

A. K. C. S. B. 151449

Whelped July 22, 1909

By Midland Rollo ex Shaftesbury Queen

Owned by Wm. Preseott Wolentt 

best, though, for an Airedale brood bitch is a short, hard, wiry coat that is inclined to be smooth on the sides and legs, and does not show much broken hair on the foreface, but is as hard as wire down the back. These breed the best coats, and a good-hred one, with a long head, of this type, is invaluable to a breeder.

Another thing I would strongly impress upon the young fancier is, never to breed from either a dog or a bitch possessed of either a light eye, a big houndy ear, or an undershot mouth. If any one of these things once gets bred into a strain, one never knows where it may crop up again and spoil a dog that otherwise would be a good show dog.

In England a good Airedale Terriel brood bitch, of first-class breeding, with no really bad faults, can usually be bought for $£ 10$

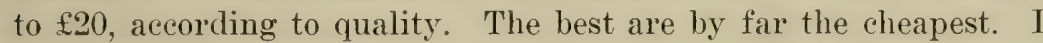
don't know the prices in America.

It is a golden rule to breed from the best, and I am a great believer in it. I should not advise any one, going in for breeding show dogs, to go in for a cheap bitch. It is false economy. If they cannot afford to buy a good brood bitch, the next best thing is to buy a puppy bred from a first-class family and rear it themselves.

A puppy at six or eight weeks old can usually be bought for the stud fee of the sire. At least that is a generally recognized rule in England. If it comes from a very successful brood bitch, it may be a bit more; but even then, it is a much better investment than an inferior brood bitch. Being bred from a first-class family, it will always sell for at least what it has cost when it is reared; while, on the other hand, there is the possible chance of its turning out a first-class show dog, as it is impossible to tell with certainty, when they are six weeks or two months old, which puppies will eventually turn out the best. In fact, it is one of the pleasures of breeding to see how the different puppies in the same litter keep passing each other at different stages; the despised one at six weeks old sometimes turns out the best in the whole litter in the end.

Some breeders don't care to sell puppies at this age, as they are afraid of parting with the best; but unless they have ample facilities for rearing them all, I think it pays them best in the end. If a breeder sells twenty or thirty puppies in a year at three or four pounds each (I am speaking of English prices now), and one eventually turns out a flier, he can always afford to buy it back again if he wants it; and even if the owner won't sell it then, and it turns 
out to be a Champion, he has always got the honor and personal satisfaction of having bred it, and it is the best advertisement that the kennel could have. I have sold two puppies at six weeks old that eventually qualified as Champions, in addition to many that turned out first-class show dogs, and I always looked upon it as the best advertisement my breeding stock could have.

IIaring selected the hrood bitch-and I don't advise the breeder to go in for more than two or three at most, and these should be of different strains if possible - the next step for the intending breeder is the selection of the Stud Dog. When a breeder owns a good bitch, he has all the hest dogs in the country to select from when he wants to mate her. Lpon the wisdom of his choice will depend to a great extent the future success of the kennel.

Some breeders alwars select their stud dogs from hig prize-winners only. They think that if a dog is a good one himself, he must get good puppies, but a show bench record is no criterion of the value of a dog at stud. Breeding to the best is a golden rule, if the mreeder is influenced not hy the individual dog alone, but by the character of his family also.

The arerage hreeder selects a dog that is strong in points where his bitch is weak. For example, if his bitch has a short head, he selects a long-headed dog for her. If she has hig, light eyes, he selects a dog for her with particularly small dark eyes. If she has a light-colored soft coat, he selects a wire-coated and good-colored dog for her. If she is small, weedy and light in bone, he selects a hig, strong-honed dog for her, and so on. If he studies individual excellence only, the very probahle result will be that his puppies will never be any hetter than their parents, and indeed may possibly reproduce the faults of hoth the sire and dam, rather than the good points of either.

The experienced and sureessful breeder goes deeper into the matter. Betore mating his bitch with the long-headed dog that she needs, he finds out whether the sire and dam of the dog he had selected were long-headed dogs, and whether they came from a family specially noted for their long heads. If he finds on inquiry that the $\log$ is not bred from a long-headed family, he looks upon his long head as being an accident, and knows that he is not likely to get the point that he wants for his bitch. He does not use this dog, but selects a dog that is not only a long-headed dog himself, but is bred from a family of long-headed dogs. The same with the bitch 


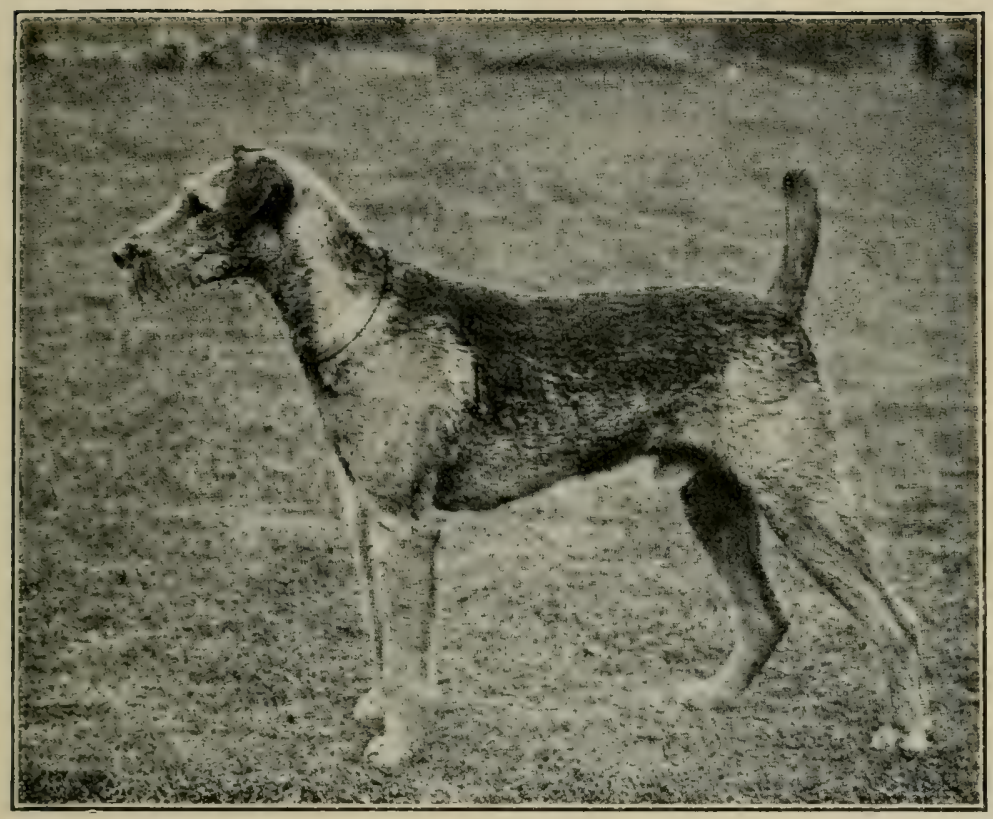

ABBEY MASTER MAGIC

A. K. C. S. B. 164589

Whelped Aug. 27, 1911

By Ch. Rockley Oorang ex Clonmel Betty

Owned by Francis G. Porter 

with the big light eyes. The dog that he had selected for her in the first instance proves on inquiry to have come from a bitch with light eyes, or with light-eyed dogs in her pedigree. He does not use this dog, of course, but selects one that has not only got small dark eyes himself, but who is bred from a family for two or three generations on both sides that had all got small dark eyes; and although this dog may not be quite as good in other points as the dog he had thought of in the first instance, he is bred right for the particular points he wants for this bitch, and he is likely to reproduce them. With the bad colored and coated bitch, and the small, weakboned bitch also, he selects a dog that is not only good in the points that he wants for his bitch, but one that is also bred from a family that is strong in those particular points.

The obvious conclusion is that a breeder, in selecting a stud dog, should not only study his individual excellence in the points that he wants for his bitch, but should also take into consideration the general character of his family, so far as the desired points are concerned. The successful breeder tries to select the dog most likely to correct the faults of his bitch, and at the same time to preserve her own good points as far as possible.

It is a curious thing, but some sires, although both well-bred and good-looking, appear to possess but little individuality, and entirely fail to stamp their own type and character on their progeny. I know of several cases of dogs bred from the same parents, and both good show dogs, where one hrother proves a successful sire of Champions, and the other brother, although just as good-looking, never gets anything good, although all sorts and conditions of bitches are bred to him. It is the same with some bitehes. Many well-bred, good-looking bitches, even when mated to sires that are most suc('essful stud-dogs, never breed anything really good, while other' bitches, no better bred and not half so good-looking, seem to breed winners in every litter. Why this is so, I do not pretend to know; I only state it to be a fact.

My advice to young breeders is to keep a keen lookout for the dog who is getting the winners, and note the general character of the majority of the puppies that he gets, and if he thinks from his hreeding and his appearance that he is likely to suit his bitch, to use him, and if he does not get the points he wants the first time, and he is satisfied in his mind that he is the right dog for his bitch, hoth in points and in breeding, to try him again, and even a third 
time, as litters hy the same sire and out of the same dam rary from one litter to another, just in the same way that the members of the same family vary in human beings, although they are all from the same parents. When I have wanted to get some particular point from a certain strain, and I was convinced that a certain dog should give we what I wanted, I have used him again and again, but I always got what $I$ wanted in the end.

1 little inbreeding is necessary to preserve the characteristics of a particular strain. My farorite method with a good all-round bitch, who has no really bad faults, but no particularly outstanding merits either, is to breed her bark to her hest grandsire, or to a good son of her hest grandsire. The latter has proved most successful for we. I am not in favor of very close inbreeding, like breeding brother and sister together. Close inhreeding is only justified when both dogs are of exceptionally good quality, with plenty of size and substance, and then only to fix some particular point; and when necessary, it is better to hreed the sire to the daughter, or the son to the dam, rather than hreed brother and sister together. Even this shonld not he done more than once every few generations, as it weakens the nervous system. The fact also must not he overlooked that by inhreeding we are just as likely to inbreed a fault as to inbreed a good quality, hence the necessity to inbreed only to the very best. A fault inbred in two generations is far worse to breed out than a fault in one generation only.

Before leaving the subject of the stud dog, I would impress upon the young fancier that perfect health, rigor, and a good. sound, healthy constitution are just as essential to a stud dog as they are to a brood hiteh. When a hitch is mated to the dog, she should be in good, hard-working condition, and not too fat. It is much hetter to have her on the lean side than too fat.

In conclusion. I would adrise the young fancier to try and establish a strain of his own. This is hest done by continuing a line on the female side from one generation to another. By keeping such a strain rumning from one generation to another, the breeder knows the faults and good qualities of each particular generation, and must have a better chance of mating them rightly, than a breeder who is always changing from one strain to another. 



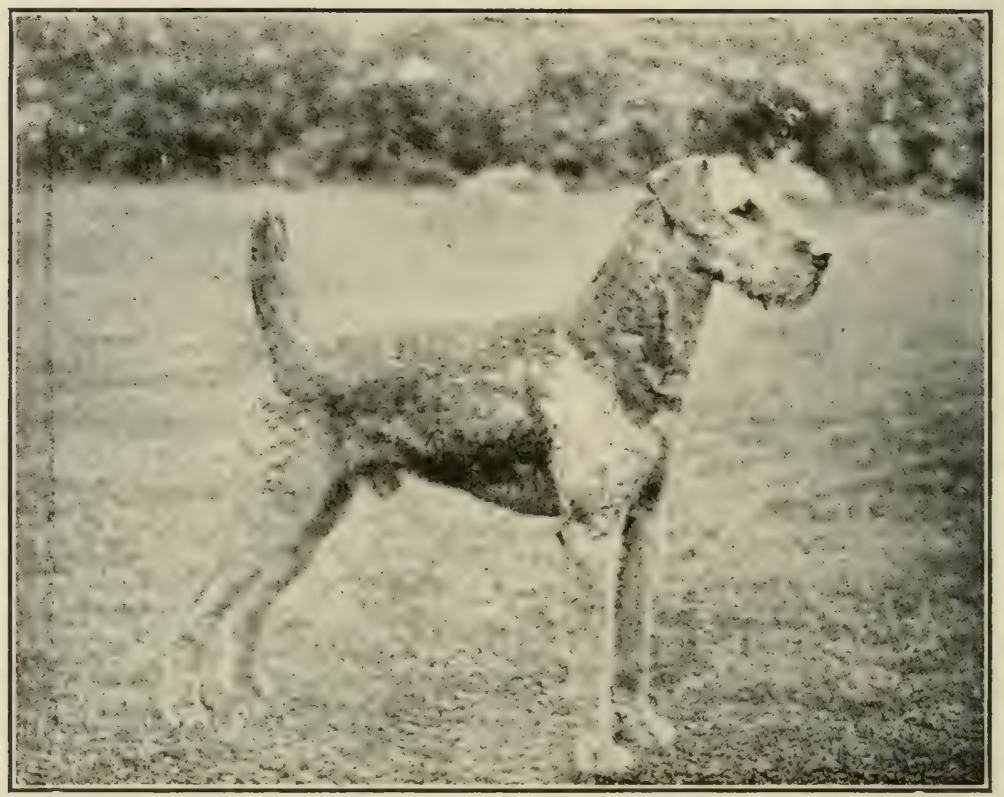

CH. ABBEY KING NOBBLER

A. K.C..., B., 1619!28

Whelped May 22, 1911

By Ch. Soudan Swiveller ex Gay Flossie

Orned by Francis G. Porter 



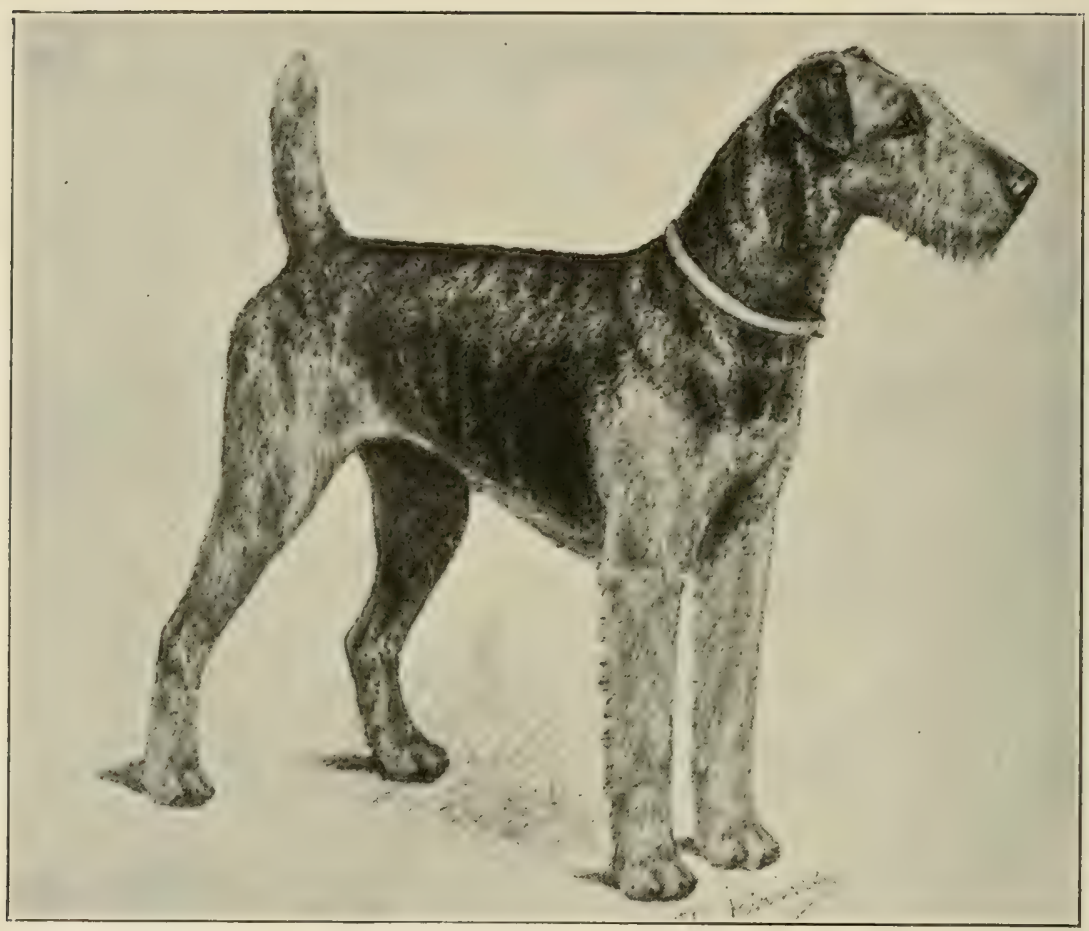

CH. KENMARE SORCERESS

A. K. C. S. B. 114241

Whelped Sept. 22, 1909. By Resemblance ex Queen Oorang Owned by Wm. Prescott Wolcott 


\section{CHAPTER IV}

THE CARE OF THE BROOD BITCH

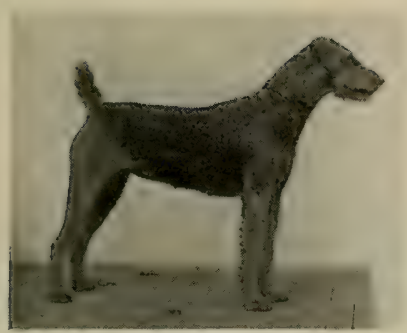

CH. LARCHMERE MISTRESS IIAGNE'T

WE will now suppose that the budding fancier has purchased a brood bitch on the lines laid down in the last chapter. He must now wait until she comes in season, which Airedale Terriers usually do when they are from eight to ten months old, though they vary a month or so either way, according to their development and the time of the year, being usually a little earlier in the spring.

A well-grown, healthy, well-nourished puppy who has lived a healthy outdoor country life, will usually come on earlier than a town-reared puppy who has not had so much liberty or exercise, and a healthy bitch will usually come in season about every six months afterwards.

When the period is coming on, the bitch will be unusually playful, and try to attract the attention of other dogs. No notice need be taken of this, except as an indication that she must be carefully watched every day to see if she has any colored discharge. The moment this is observed, she should be locked up in a kennel by herself, where it is impossible for her to escape, or for any other dog to get to her. Where a bitch has to be left to the care' of servants, who may have very little knowledge of dogs, I should strongly advise the owner to attend to this himself, as however obedient a bitch may be at ordinary times, she will obey her instinct, and escape, if she can, when she is in season.

The period usually extends, from first to last, over three weeks. Bitches vary very much in the time when they will permit the approach of the dog. Some are quite ready in seven or eight days, while other's are fourteen days or orer sometimes. The best time to breed her to the dog is the first day after the colored discharge 
has died away, but it may he taken as a general rule to follow, that whenerer a hitch is really keen on the dog, and shows by her actions her desire for his presence, that is the right time to breed her to the dog.

If a hitrh has to be sent a long distamce by rail to visit a stud dog, it is hest to send her in good time, when. she has been discharging about five days, as most owners of stud dogs would prefer to keep a bitch for a few days before service, rather than run the risk of her roming ton late, as a long railway journey often upsets a biteh, and when she is near the end of her period it may cause her to go off season altogether.

Aredents will happen sometimes, and in spite of all precautions a highly hred bitch will escape and contract a misalliance with a mongrel or a dog of another breed. Many a valuable hiteh has been destroyed for this, hecause her owner had an idea that she would be of no more use to breed from, and that her future litters would be tainted. I know that this idea is prevalent among many breedros. hut soientific opinion is aninst it, and my personal experience is also against it; and if she is tried again to a pure-bred dog, I think it will he found that her puppies will he all right, and will show no traces of the previous misalliance.

When a bitch comes in season, it is always wise to give her a good rlean-ont for worms hefore mating her to the dog. By doing this, the hitch herself will he stronger and healthier when carrying her puppies, and the puppies themselves are not so liable to be inferoted with worms when they come.

Some breeders mate a bitch every time that she comes in season, hut this is a great strain on her constitution and cau only be done successfully with those that live a free, healthy country life. Bitches that are kept in kemmels in hig cities, and don't get much natural exereise, should only be bred from in the spring of the year.

Amongst even experienced breeders opinions vary as to the wisdom of hreeding a hitch the first time she comes in season. Some breeders argue that a biteh would not rome in season at all if nature did not intend her to breed puppies. ()ther breeders never mate a bitch the first time she comes in season, as they argue that she is not then fully matured, and that her puppies are not as big and strong as those from an older bitch. Personally, my opinion is that it is hetter to wait until the second period, except in the case of a big, well-grown, healthy bitch who comes in season just in the 


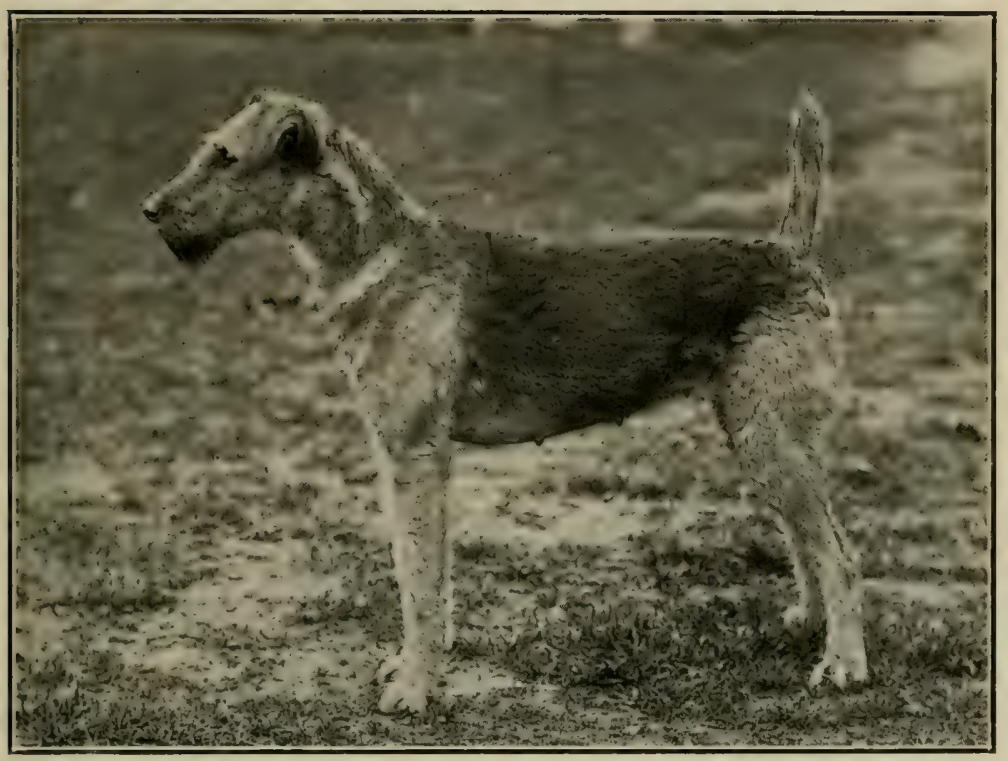

CLONMEL IMPERIOUS

A. K. C. S. B. 156304

Whelped Dec. 27, 1910

By Ch. Crompton Oorang ex Glamora Princess 



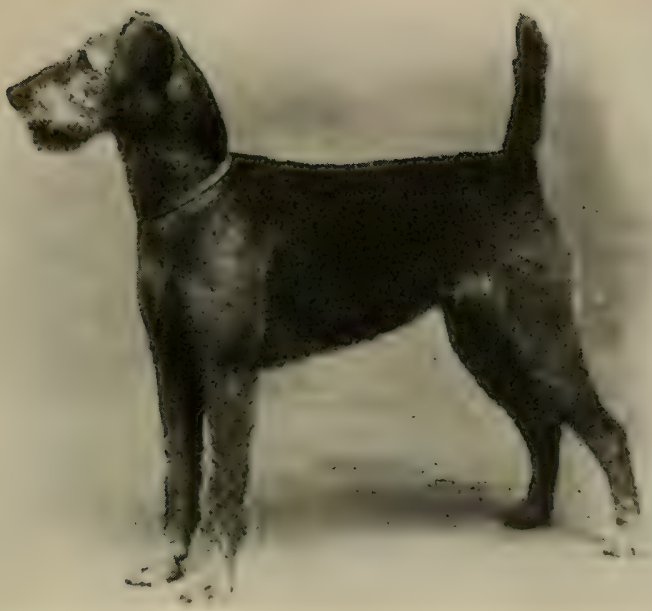

SOUDAN SAPPHIRE

A. K. C. S. B. 149275

Whelped Nov. 7, 1907

By Springbank Performer ex Newfield Sunbeam

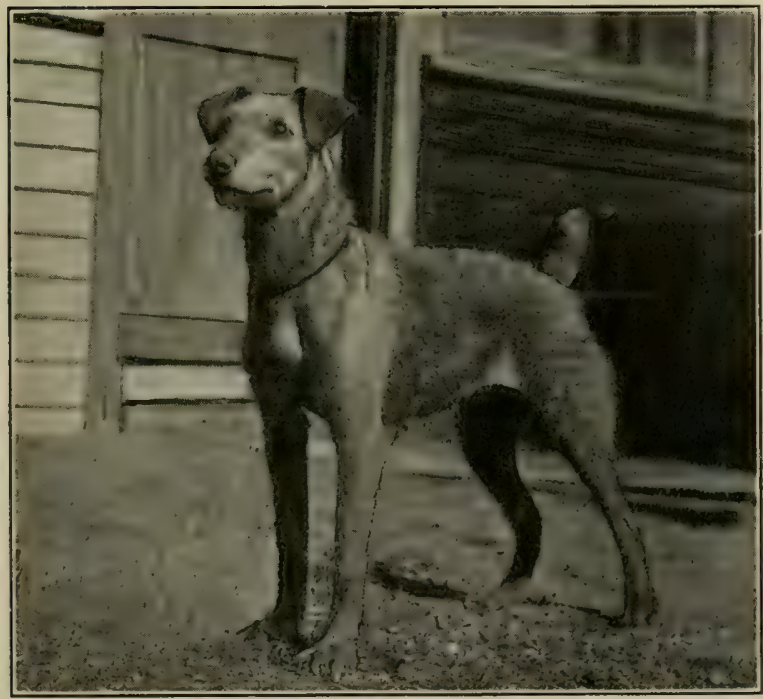

DUMBARTON VIXEN

At 11 Years of Age 
spring of the year, as it must be a great strain on a young bitch to rear puppies.

Some breeder's like a bitch to have two services, with a day's interval between them. Other breeders are in favor of one service only, as they find that they have fewer puppies with one service thin with two services. They argue that it is much better to have six or seven strong, healthy puppies than nine or ten small, weedy ones. My own experience has certainly heen that I have had, on an average, larger litters with two services, than I have had when the bitch has had one service only; and in a breed like the diredale Terrier, in which size aul substance are of such great value. I think it is hest to have one service only. if the hitch is caught just at the right time, provided that the $\log$ is a comsistent stock-getter and the bitch is a rertain breeder. The best time of the yeal to have puppies borm is undoubtedly in the spring. They have then all summer in front of them, and can he easily reared outside. Sumshime is as esisential for puppies as it is lor all animal life, and the mole they (an get of it when they are young. the better it will he for them.

Atter the hitrh has heen mated to the dog: and her period of being in season is muite orer, she should be allowed to have her "utio liberty as murh as possible. This is not always possible in towns, where there is danger of a valuable biteh heing stolen if she is allowed to roam ahout by herselt. In that case it is much hetter to let her have gentle walking exercise at frequent intervals, lather thau take her for long. tiring walks. She should be fed generously all the time she is in whelp. and given plenty of new milk, brown bread, and oatmeal porridge, with fresh, leau, raw meat twice or four times a week. Great care should be taken to prexent her fighting. as it upsets her and often causes a miscarriage.

A bitch is che to whelp sixty-three days after being mated to the dog. but they often viry a few days. most bitches whelping a day or two before their time. If the bitch is at all costive during the latter part of her pregnancy, a tablespoonful of regetable oil or castor oil should be given every other day.

About a fortnight hefore her puppies are expected, she should be placed where she is going to whelp, so that she will be quite settled down when they are due. She should not be housed with other dogs. hut should he kept out of sight or hearing of them if possible. Warmth is of the utmost importance until the puppies 


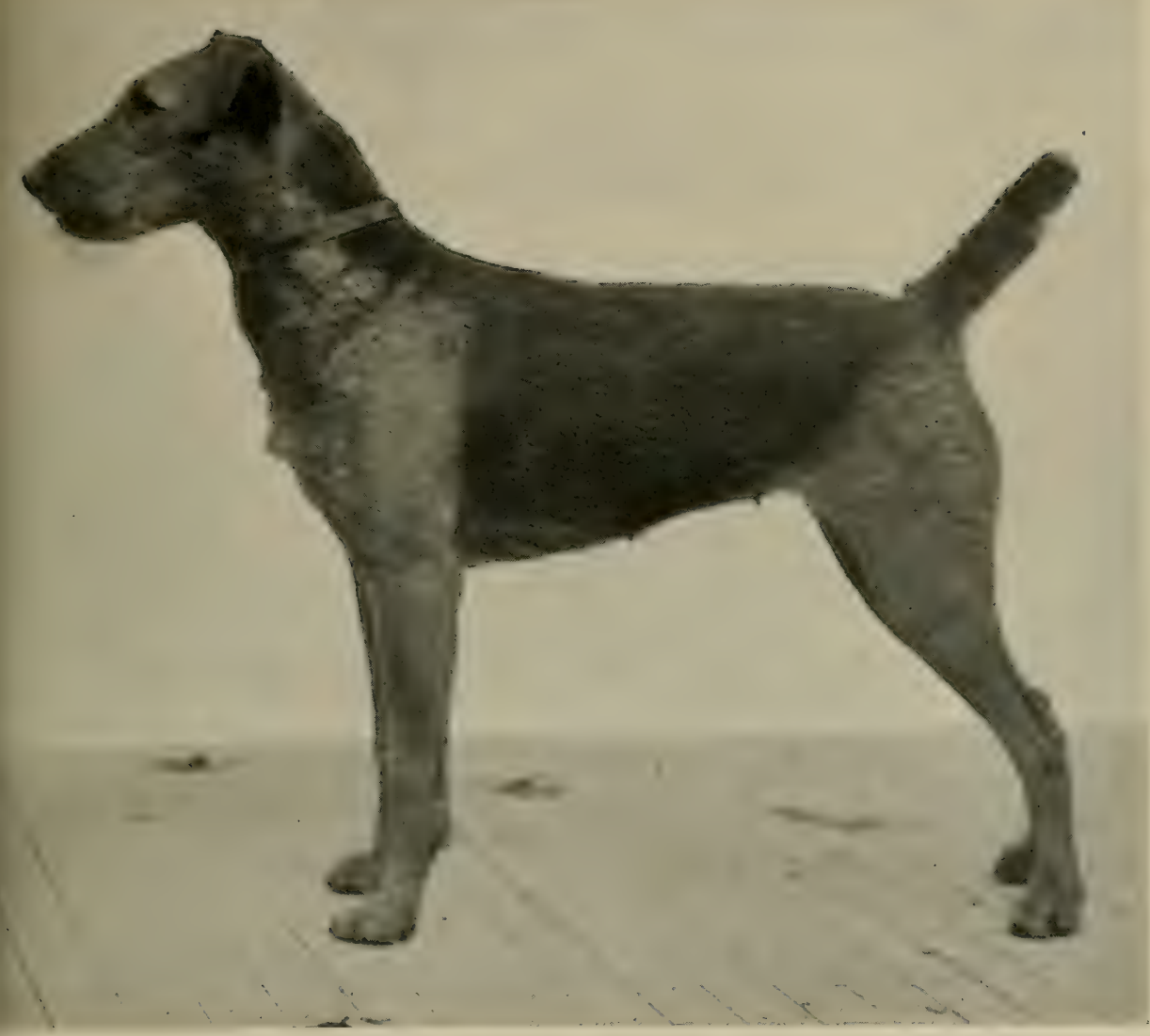

VICKERY VESTA

A. K. C. S. B. $156180^{\circ}$

Whelped April 25, 1910. By Tintern Desire ex Ellerslie Vesta Owned by Vickery Kennels 
are three weeks old, and if it is not convenient to put her in a room where there is artificial heat, the next best thing is to put her into a stable, or cow shed, where horses or cows are kept, as it is generally warm there. If, however, this is not possible, she should be placed in a warm, dry, sumny kennel, with a box at least three feet six inches square. filled with a nice bed of straw for her to whelp in. It is best to have two boxes, so that one can be well dried and disinfected while the other is in use.

The bitch should have free access to a bowl of fresh drinking water, and be left to herself as much as possible. When it is seen that she is in lahor, it is not wise to interfere with her, as Airedale Terriers, if strong and healthy, do not often require any assistance. and the less they are bothered at this time the better, as they are apt to get excited if they are interfered with, with the result that more harm is clone than good; so, beyond just looking at her oceasionally to see that all is going on right, it is best to leave her alone. Nature teaches her what is necessary.

When she has quite finished whelping (which may take from four to twelve hous or even longer), her hed, which will now be quite wet, should be removerl, and she should be placed with her puppies in the second hox. which should have a nice clean hed of straw. The hox that she has whelped in should he rleaned out and disinfected, and dried ready for use again.

Whe need not be fed for some hours, as she will eat the afterbirth, but should be left to rest for a while, and not be disturbed. The hox should he changed every day, but beyond this, the puppies should be interfered with as little as possible until they are three weeks or a month old.

After the bitch has had a good rest, and is nicely settled down with her puppies in her new clean hed. a little boiled milk or thin gruel may be offered to her about every four hours, but she usually does not want much for the first day or two. If she will not drink milk, a little sheep's-head hroth poured over stale brown bread or hoiled rice may be offered to her. If this also is refused, it should be taken away, and she should not be offered anything again for four hours, but left with a dish of clean cold water close to her, so that she can drink when disposed. After the third day she may begin to have solid food, such as meat, regetables, scraps from the table, hrown bread and milk, or soaked dog biscuits with sheep'shead broth poured orer them. All feeding ressels should he kept 


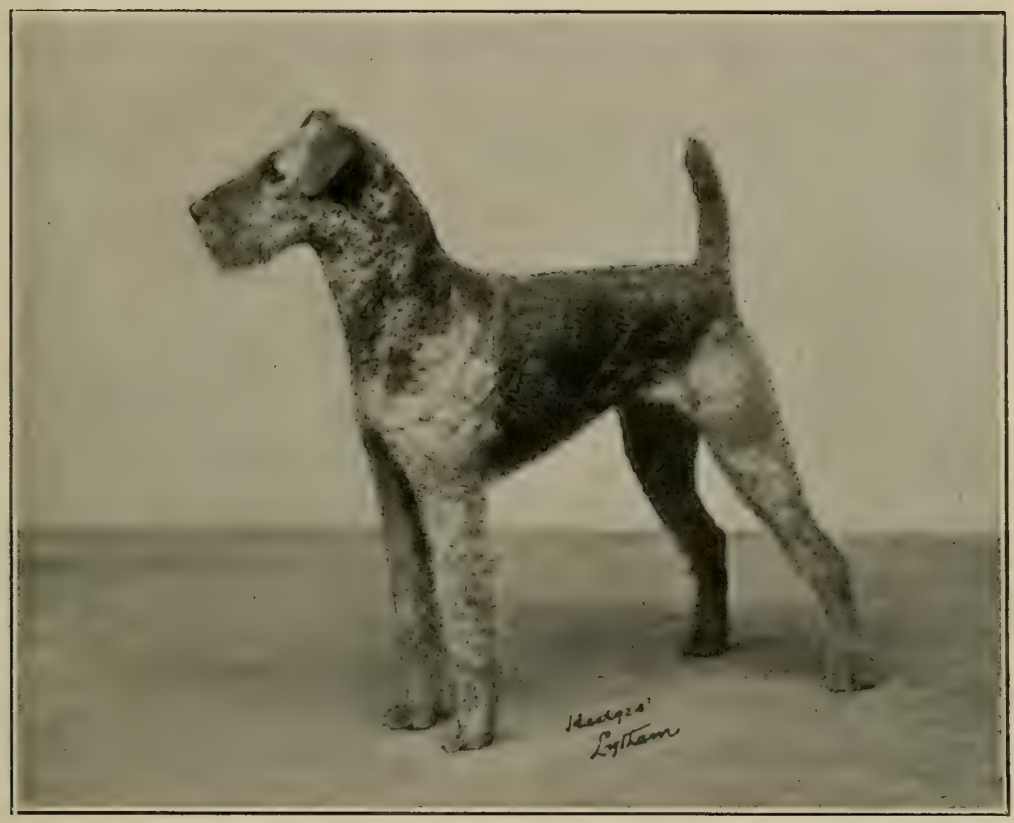

CH. DARGLE DEPUTY

E. K. C. S. B. $382 \mathrm{~S}$

Tintern Desire ex Victoria Madge

Owned by Wallace Marrs 
sweet and clean, as the bitch is liable to be easily upset when in this condition.

The health of the nursing mother is of the greatest importance, and if her milk should be poor in quality or scauty it is far better to get a foster-mother. A foster-mother need not be of the same breed, but should be as near the same size as the mother of the puppies as possible. She must be in perfect health, and have whelped within a few days of the puppies she is intended to murse. As the puppies grow older and stronger. the mother's hreasts are often made sore hy the puppies hiting and scratching her with their little sharp claws, and at length they will often cause her so much pain that she is almost af raid to murse them. She will he greatly relieverl if her hreasts are gently rubhed with marshomallow ointment. which will not harm the puppies if they get it into their months.

The puppies should have their tails dorked and their dew-elatrs taken off when they are from five to seven days old. This ean be

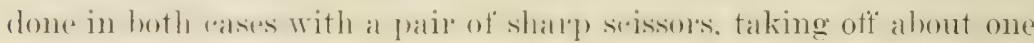
third of the tail.

The bitch, if she is a good mother, will be very keen on her puppies at first and will not leave them far for the first week or two. Her kennel door should be left open, so that she can come and go just as she pleases. She will he all the hetter for at little chamge and fresh air, and will not neglect them, but will go in and nurse them.

The puppies should be induced to lap as early as possible. It relieves the mother, and the puppies are all the hetter for it. At three weeks old they should he taught to latp milk, or lactol, which I have found very good indeed for getting the puppies on. The milk should not be mixed with water, as the bitch's milk is much stronger than either corrs' or goats' milk. They should be fed on nothing but new milk which has been boiled and cooled down, lactol, brown bread scalded with new milk, boiled rice. oatmeal porridge, or Quaker oats, until they are two months old.

T'he mother will usually lick her puppies and clean after them when they are in the nest. This is liable to upset her stomach, and sometimes afleets her milk, and it is a good plan to give her a dose of eastor oil once a week while she is nursing them.

It is not wise to let a bitch rear more than six or seren puppies herself; if there are more, it is best to destroy the remainder, or get a foster-mother, as it is far better to have six or seven big, strong, healthy puppies than nine or ten weedy ones. 



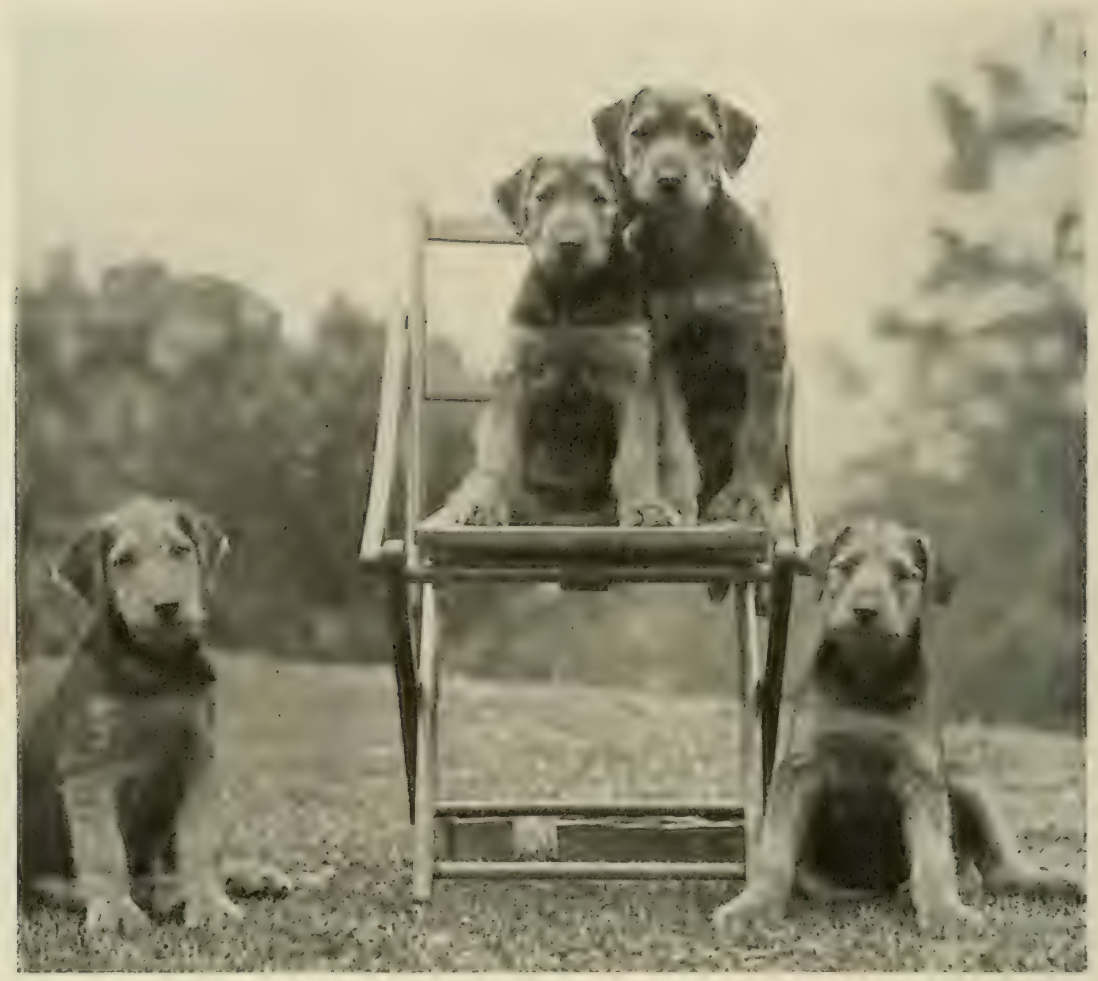

A TYPICAL LITTER OF'

AIREDALE TERRIER PUPPIES 


\section{CHAPTER V}

THE SELECTION AND REARING OF PUPPIES

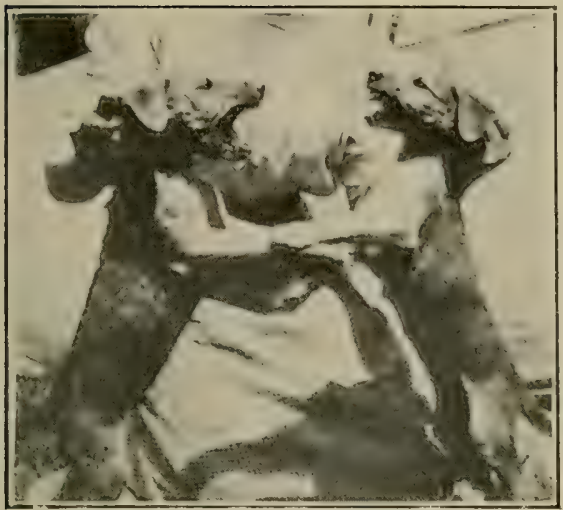

A COUPLE OF BOTHIVELL PUPS Showing the spirit of their sire, Prince of York
WhEN the puppies are six weeks old, they should have been feeding themselves for some time, and are quite old enough to leave the mother; so, unless the owner has ample facilities for rearing them at home, they should be sent "out to walk," as it is called in England, to be reared.

If they are going to be reared at a farm in the country, it is better to send two to each place, as they exercise themselves better and amuse one another better than if sent singly, but two are quite enough for one place.

If they are going to be reared at a cottage in or near a town, I think it is better to send one puppy only to each place, as a woman will often take one puppy to live in the house, where it will get plenty of exercise by playing with the children, who will often make a pet of it, and take it about with them, while if two are sent, they will be shut up most of the day in some outbuilding, and will not get half the care and attention they would have if they were reared in the house; and in a breed like the Airedale Terrier, where size and substance are so very essential, this is an important matter.

When six weeks old it is impossible to tell which puppy will eventually turn out the best. Sometimes the least promising one at this age turns out the best in the end, and when the financial side has to be considered it is never wise to refuse a good price.

Puppies from fashionably bred parents often sell better when 


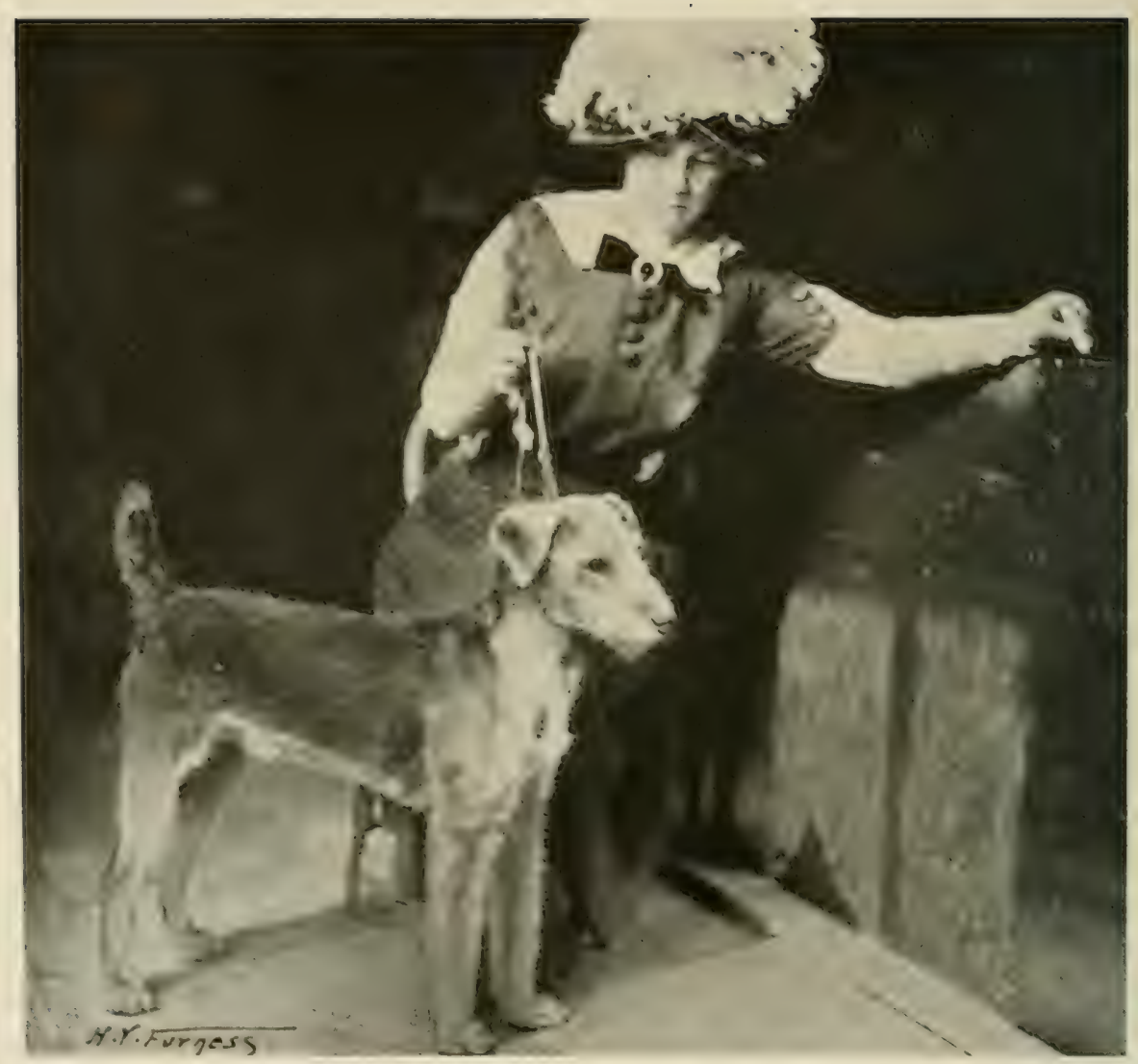

MRS. CRAWPORD WITH LODESTAR WHEN A PUPPY 


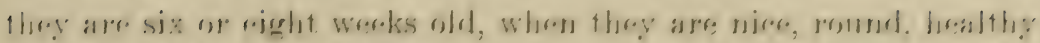

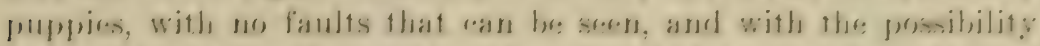

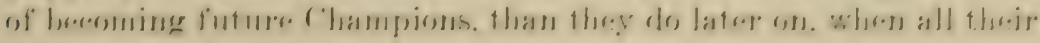
imperfecetions can be seen.

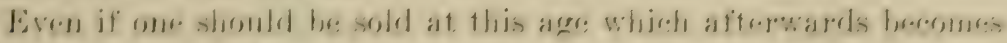

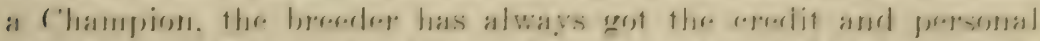

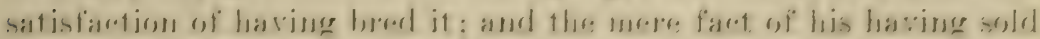

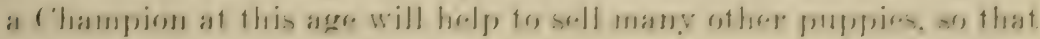
he will not be a Joser in the end.

The novire should select the puppies which have the Iongest

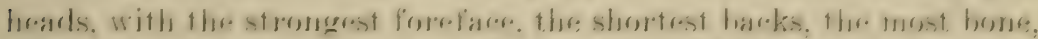

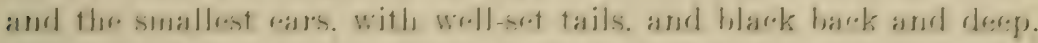
rich tan. 'The negative points to be looked for are an undershot

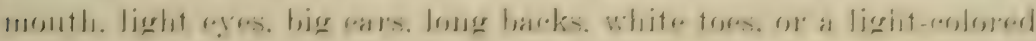
sofet reosit.

When there are two doubtful specinens and one of them has to

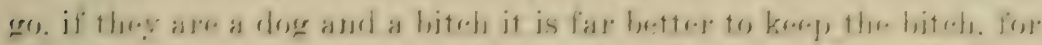

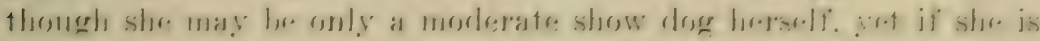

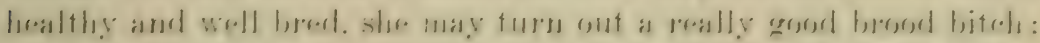

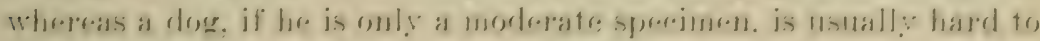
dispose of, and is not much value as a stud dog.

I should like to impress upon young fanciers that it never pays in the end to send out a weedy or a weakly puppy. 'They will not

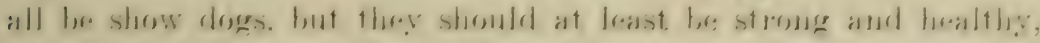

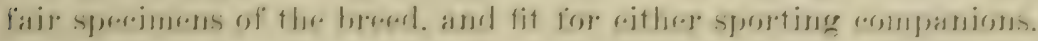
house guards, or stud purposes.

Puppies are often troubled with worms, even at six wereks or

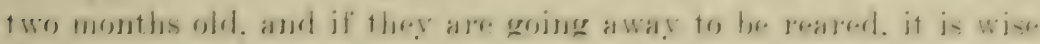
to give them a dose of worm mediceine before they go. A stock

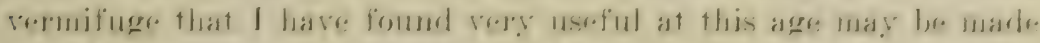

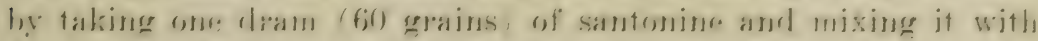

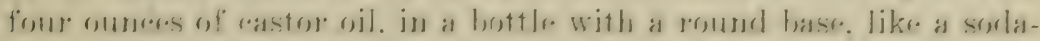

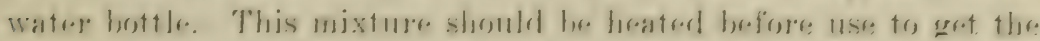
surplus santomiur reolissolverl. A teaspornfoul of this mixture.

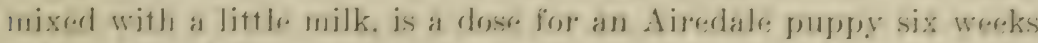
old. and shombl beregen fasting in the morninge If the first rose is

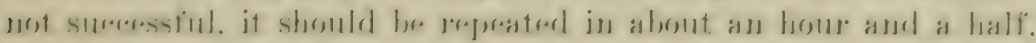

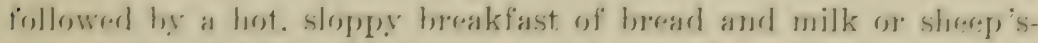

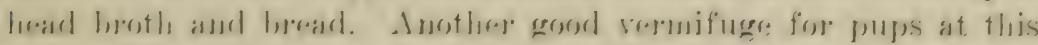
age is to give one grain of freshly powdered areca nut for every 
pound the puppy weighs, followed in an hour by a dessertspoonful of castor oil.

Puppies bred from strong, healthy parents are not half as much trouble to rear as puppies bred from parents that are weakly and of bad constitution. The former will eat any good plain food that comes first, and are always merry and bright, and full of health and spirits, romping and playing all day long. They are a source of real pleasure to their owner, who delights to watch them and attend to them. If properly fed, they grow into hig, strong, healthy dogs that are goor either for sport or to stand the strain of travelling from show to show. Puppies bred from parents of weak, poor constitution have never the same vitality to begin with, are twice the trouble to rear, and if they do happen to have a lot of good show points, they have to be drugged to get them into show rondition. and are never as good, either to breed from or for sport.

The one great secret of puppy rearing is to feed little, and feed often, and never on any account to overfeed. Six times a day is not too much till they are three months old, then four times a day till they are six months old, then three times a day till they are twelve months old; after that age, a dry biscuit or a handful of dry homml-meal in the morning and a square meal at night is quite enough for any adult dog. exeept for a stud dog, or a bitch in whelp. who should both be fed very aenerously with plenty of fresh, lean raw meat. I am a sreat heljever in oatmeal porridge and new milk for rearing pupples, and this, with wholemeal hrown hread and new milk, fish heads hoiled until the hones are dissolved. Quaker oats. or sherep's-head broth poured over hrown hread and house scraps. with a little fresh, lean raw meat oceasionally, should be their staple food till they are six months old.

One of the best puppy walkers I ever had was an old gardener who made milk and oatmeal porridge their staple food. He boiled as much oatmeal at one time as would last them two days, then poured it into another vessel to cool, and heated it up afterwards by pouring hot milk over it, to which he added a little treacle to sweeten it, feecling five or six times a day. His only variation was a few scraps from the house, and a boiled sheep's-head or two occasionally. Whaterer mistakes I made myself in breeding the puppies, as far as show points were concerned, one thing I could be always sure of, and that was that any puppies that he reared would always be big strong dogs, with perfect legs and feet, strong firm 
backs, and as merry and active as young kittens. My experience is that well-cooked oatmeal and undiluted new milk are unequalled for making bone.

In feeding puppies, it is much better to feed them separately than to feed them all together out of the same dish. In the latter case, the strongest ones push the weaker aside and eat more than they should do, while the weaker ones do not get as much as they really need. By feeding separately, every puppy gets its proper share-neither too much nor too little.

I would impress upon the novice that these two rules-feed little and often, and feed separately - are the two greatest factors in successful puppy rearing. Note the difference between a puppy fed in this way and another that is allowed to gorge himself three times a day. The latter, when he has been fed, crawls away with distended stomach to sleep off his heavy meal; while the former, instead of sleeping, is all for play, stands firm and true on his legs, and is ready to play with anything that turns up.

The norice must also bear in mind that a heavy body is so much weight on the legs, and that the legs of a young puppy are weak, and to allow a young puppy to gorge himself is a sure way to get weak, bandy legs and badly placed elbows.

Puppies should never be fed until their abdomen is distended, but should be made to leave off eating while they are yet ready for more, and they should be kept as much as possible on their feet, and encouraged to play and exercise as much as possible, and have a warm, comfortable bed that they can go to whenever they feel tired out.

When the puppies are born in the spring, and the weather is fine and the ground dry, they are all the better for being out in the sunshine for about half an hour two or three times a day, when they are from three to six weeks old. In fact, the more they get into the sunshine, except in the hottest part of the day, until they are six months old, the better it will be for them. Sunshine is as essential to puppies as it is to all animal and vegetable life.

When the puppies are four months old, they should be taught to kill rats. It is the first thing an Airedale Terrier should learn, and it helps to make them hardy and gives them courage and confidence that is useful in the show ring afterwards. I have had puppies that would kill cleverly at three months old, but I think four months is perhaps soon enough. 
Siome people expect an Airedale puppy to kill rats at first sight. and some of them will do so, but this is surely unreasonable to expect. Ip to this time, if the puppy has attempted to give rent to his natural instincts hy (chasing fowls, sheep, "ats, etc.. it has been checked by its master and severely rated. for doing so; yet there are people who, in spite of this, expect to see him rush in and kill the first rat he sees, when he does not know whether he will be doing wrong or right. 'This is not quite fair to the puppy ; he should first be shown what he is expected to do.

IIe should be held, aud allowed to see an older dog kill some rats. then he should be encouraged to take hold of the dead rats and carry them about in his mouth, and be plainly shown what he is expected to do. If he can be taken where a corn stack is being ferreted, or to where other dogs and ferrets are working around some farm hniltings. he will soom learn to take a hand in the game, as it comes natural to an Airedale 'Terrier. If he is led gradually on, step by step, without putting him to something beyond his strength and powers, there are very few things that he will not dare to tackle when he is full grown, if he is told by a master in whom he has every confidence.

As this may not be practicable for a townsman, I have a method of my own of entering a puppy to rat-killing that may possibly interest some townsmen who have not the advantage of living in the country. I have a hay loft over my stable, in which every hole has been carefully cemented up, so that the rats cannot possibly escape. When I want to try a puppy, I send for a cageful of rats. and then lay big heaps of straw at intervals all over the floor. I then open the door of the cage and allow the rats to escape. In a few seconds they have all taken to cover under the various heaps of straw. I then fetch the puppy, tum him loose in the room, and sit down and light my pipe. In a little while the puppy, finding that I will not play with him or take any notice of him, begins, puppy-like, to investigate the room, with the result that he probably disturhs one of the heaps of straw where the rats are concealed. and causes a laat to holt and sexk another "over. The puppr, seeing the rat and winding something new. chases him to the next heap of straw, where the rat takes cover again, and when the puppr pushes his head in after it to investigate. the rat either holts again, when he chases after it, or the puppy gets hitten for his curiosity. If he is naturally a game one. this puts him on his mettle, and. enrouraged 
by me, he generally has a go for it, and after a struggle usually kills it, sometimes getting badly bitten by an old rat. It is great fun, when he has won his first battle, to see him swagger around with the rat in his mouth, as if he owned the whole earth. In a little while, when he has settled down a bit, I take the rat from him and make him understand that it is dead, and then show him where some of the other rats are hidden. He is keener this time, and usually kills the second in about half the time he took to kill the first one, and so on until he has finished the lot.

This method seldom fails. If the puppy does not take to it at first, I fetch out an old dog to show him how it should be done. It also has the advantage of teaching him to put down his nose and hunt, as he knows perfectly well, after he has killed the first two or three rats, what he is hunting for.

When the puppies are six or seven months old, the dogs that promise to make winners should be taken in hand and trained for the show ring, and the others drafted out and sold for house guards or sporting rompanions; and the sooner this is done, the hetter, as they only take up room that better dogs should occupy. 


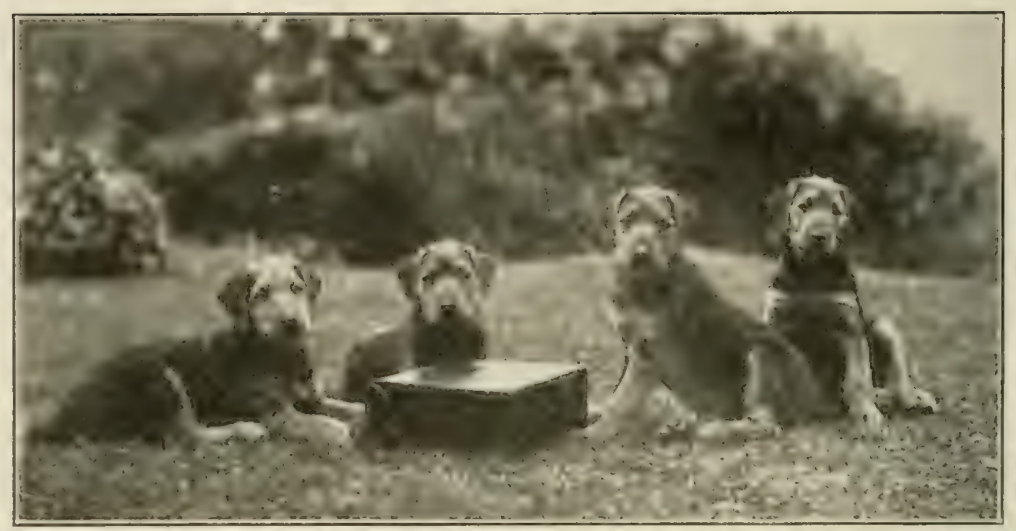

1 I ITTER OF

EIGIIT WEEKS OLD ENGLISH PUPPIES 



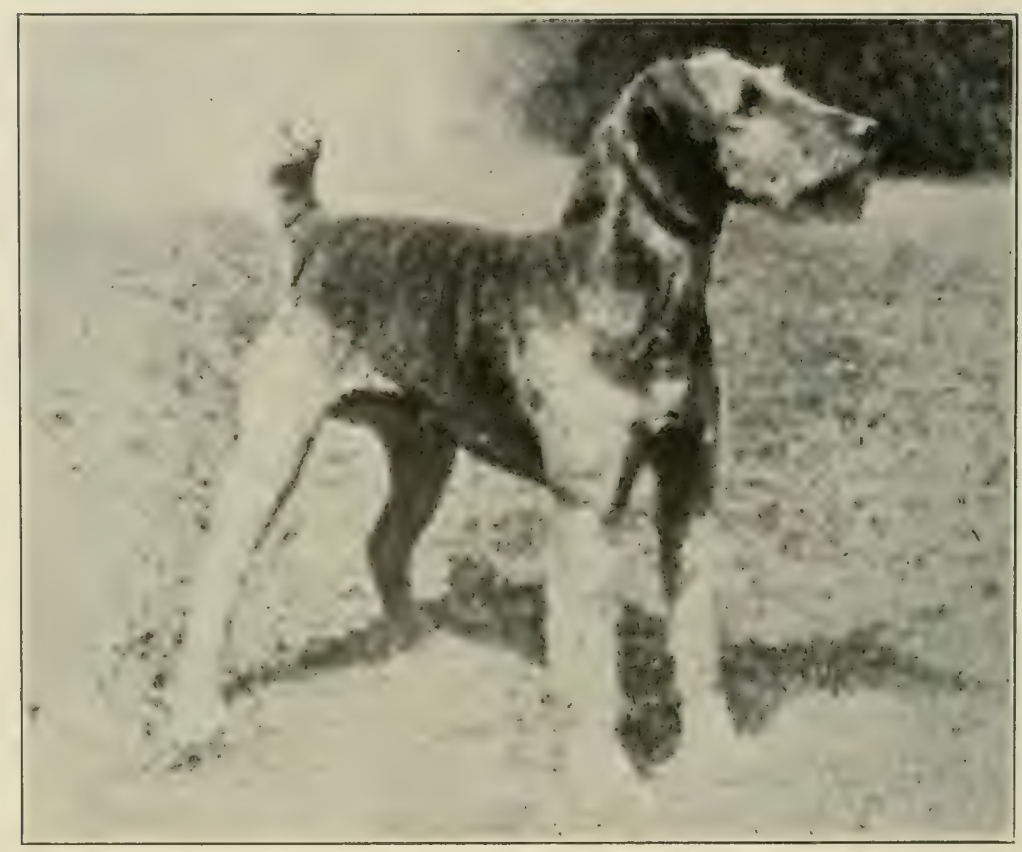

CII. PRINCE OF YORK

(Ch. Danny Graig Commander)

A. K. C. S. B. 14182:

Whelped April 4, 1907. By Ch. Crompton Oorang ex Daisy Marvel

Owned by Vickery Kennels 


\section{CHAP'TER VI}

HOW TO 'TRAIN AND CONDITION FOR THE SHOW RING

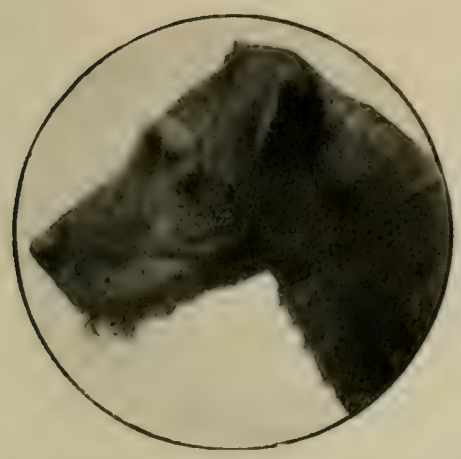

CH. 'TINTERN ROYALIST'

WIIEN the puppies are about six or seven months old, those that look like making winners should be taken in hand and prepared for the Show Ring.

If the puppies have been kept out at walk, the probability is that they will have had very little grooming. and their coats will be in a rough. patchy condition. All this outer coat should be taken off with fingers and thumb, down to the inner coat, so that when the top coat grows again, it will be all nice, new, even coat of the same age and length. It will come off quite easily and will not hurt the puppr at all. A good-coated dog will take two months or even longer to grow a nice new coat, but a soft-coated dog will probably be ready in four or five weeks, as a soft coat grows murbl quicker than a hard, wiry one.

The puppy should be well combed daily, with a fine steel comb that will take away all the soft downy hair, and afterwards be well brushed with a hard dandy brush, finishing off with a goor rub down with a hound glore, for about five minutes. This makes the roat lie rlose and dense, and hoth gives it a polish and makes it handle harder.

If this is done regularly, and all the old dead coat is picked out as it makes its appearance, a dog with a good natural wiry coat will be in show condition all the year round, as he will nerer get reallyhad; but a bad-coated dog will have to he stripped again in a few weeks, as it soon grows too long and shaggy.

However cleverly a really bad-coated dog may have been trimmed, it seldom dereives an experienred judge. who ran always 
tell when a dog has a good natural coat, and will rightly penalize one that has been overtrimmed.

About a month before the show, if there is the least suspicion that the puppy has worms, it is wise to give it a good dose of worm medicine. There are many good worm medicines advertised, but I like the old-fushioned areca nut and santonine combination as well as any. For a well-grown Airedale puppy about nine months old, give 40 grains of freshly grated areea mut mixed with 3 grains of santonine and made into a pill with lard or butter, all to be followed two hours afterwards with an ounce of eastor oil. Then feed on some hot, sloppy food and give walking exer(ise until the operation is completed. For an adult Airedale the dose would be 60 grains of areca nut and 4 grains of santonine.

I don't believe in giving drugs to a dog to get it in show condition, as this an be done much better by a suitable diet, plenty of exereise, and strict attention to cleanliness. The only medieine that I erer give to my own dogs, with the exeption of an oceasional dose of rastor oil or worm medicine, is a teaspoonful of milk of sulphur in their soft food once a week. This appears to keep their blood right, and I seldom have any skin disease in the kennel.

In ardition to the ordinary exereise the puppy gets, he should now be walked on a long lead for ahout an hour daily, on the hard road if possible, als this is grood for his feet. and keeps the mails down and also helps to get him into good. hard condition. If he is taken oecasionally amongst traffic and other dogs, he will get acerustomed to them and will be all the better for it.

Some Airedale puppies do not take kindly to the leader at first, especially country-reared puppies that have had their entire liberty up to this time. With this lind of dog the only thing is patience and kindness, as they often make the keenest showers in the end. when they have got over their shyness. Puppies have to be trained and broken for the show ring, and taught to make the most of themselves, just the same as a show hackuey has to be broken and taught to show off all his best points.

If the puppy will not go in the leader at first, don't drag him along the road, but take him home again and turn him loose in the kennel yard with the leader fastened to his collar, and let him drag it after him for about a quarter of an hour, twice a day, until he gets quite aceustomed to it. Then he appears to be no longer afraid of it, pick up the end of the leader oceasionally, and after attract- 


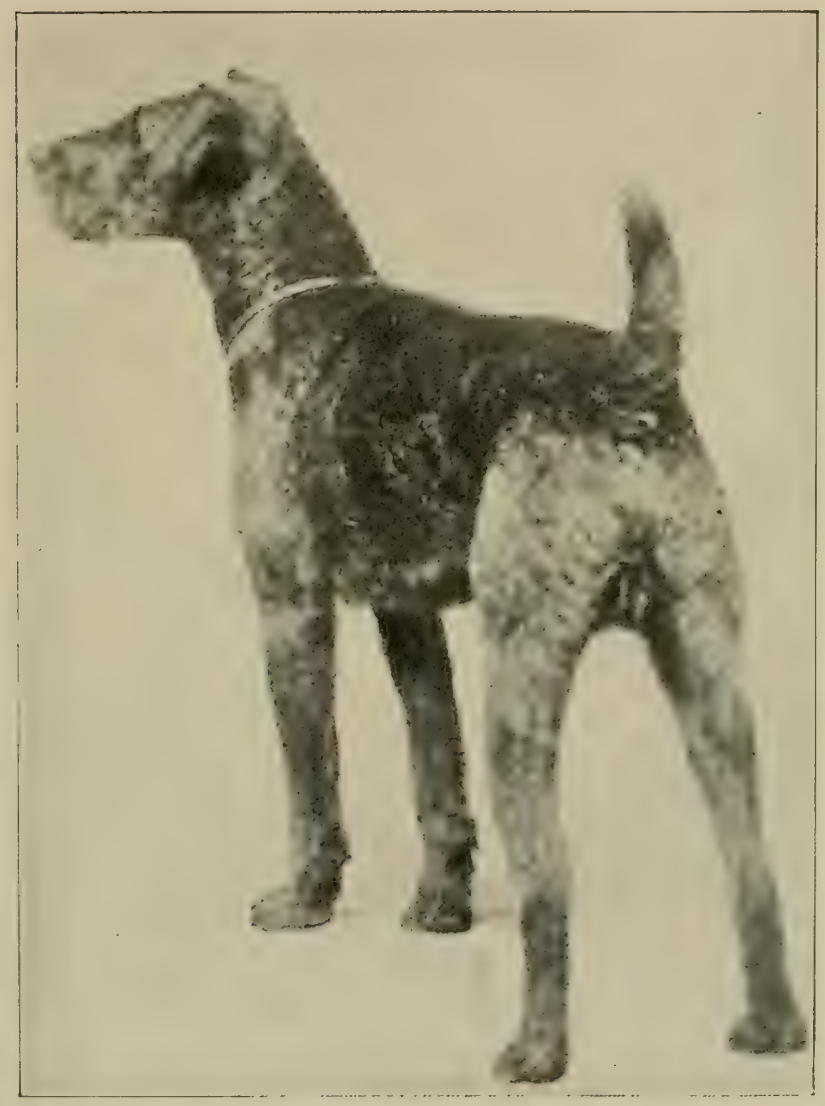

CH. TINTERN ROYALTST

A. K. C. S. B. 1335457

Whelped June 28, 1908

By Tintern Desire ex Tintern Blossom

Owned by Viekery Kennels 

ing his attention, throw him a few pieces of meat. He will soon begin to expect this whenever the leader is taken up. Encourage him to romp and play with the leader on; throw pieces of meat for him and let him gallop after them, still holding him by the leader, and he will soon begin to think that it is a game that he likes, and will be as keen on it as his master.

When out walking on the road, the owner or trainer should always carry a few pieces of meat in his pocket, and if the puppy is at all afraid of anything that he meets, he should be petted and encouraged until he has got over his fear, and not be bullied; and if he is systematically treated with kindness in this way until he outgrows his puppyhood, it will take a lot to frighten him when he is a fully matured dog.

When his owner sees a chance, in a quiet place, he should pull him up and teach him to stand with his head and tail up, on the alert. Throw him a few bits of meat, and he will soon learn to stand and pose like a hackney stallion. Then walk on another mile, stop, and give him another lesson, and it is surprising how soon he will learn what he is expected to do; and when he is taken into the show ring he will always beat a dog that may be just a little better in show points, but does not make the very most of himself.

When he has got thoroughly aceustomed to the leader, chain him up to a post, and tell him to stop there, and then walk away and leave him. On your return, pet him, and give him a few bits of meat. and let him see that he has been all right, and that you expected him to stay where he had been fastened. When he has once learned this lesson at home, it will save him a lot of worry and trouble when he goes to a show and is fastened on a show bench for the first time.

When a fancier cannot spare the time to give a dog this road exercise, it can he kept in fairly good condition if it is taught to retrieve a ball for a few minutes two or three times a day, though too much of this has a tendency to make them go in shoulder's.

In the summer time it is never wise to give severe exercise in the middle of the day, "when the sun is at its meridian," but always in the morning or the evening, when it is cooler.

The puppy should be fed on food that will make good, firm, hard muscle, and not fat. It should not be orerfed, but should be fed lightly, three times a day, after exercise. A dry dog biscuit, or a little dry hound-meal, will do for hreakfast: a little perfectly fresh, 
minced lean raw meat at noon, with a soft feed, at night, of soaked dog biscuits or brown bread, well mixed with green vegetables, sheep's-head broth and meat or fish, will make a nice, raried, and nourishing diet.

An diredale Terrier should always be shown in good, hard-working rondition and not too fat. It should be in good health and spirits. with the eyes clear and bright, the coat and skin in perfect condition, and he full of vim and fire, so that it will make the very most of itself in the show ring.

I would strongly urge the romer fancier never to show his dog muless it is in perfect condition, hoth in health and in coat. More novices have given up dogs through doing this than anything else that I know of. They show a good dog in bad coat and form generally, and get put down helow dogs that they could easily beat if their dogs were in better comdition. Some astute professional notes the dog's sterling qualities, and huys him. well knowing what he can do when he is put down in hetter form and condition. IIe spends time with him and gets the dog into good form, when he rightly heats the dogs that beat him whem he was owned and exhibited hy the novice. The novice then often blamies the judge, when it is his own fault entirely.

I strong. (apable judge will always judge the dogs on the form they show when he is judging them in the show ring. The does not take into consideration what they may have done in the past, or may possibly do in the future. He judges them as he sees them before him at the moment. If a dog loses under a particular judge at one show, there is no reason whatever why he should not beat the same dogs, muler the same judge, at another show. if the dog is then put down in hetter health and condition, and shows himself better.

There is a great art in handling a dog in the show ring, so as to exhihit all its hest points to the judge, and as few of its bad ones as possible. At the same time, it takes a very clever handler to deceive an experienced judge, who has generally been through the mill himself, and is quite awake to all the little dodges. I remember old George Hallewell - "Yorkshire George," as they used to call hin-onere julging at Bingley. when a certain well-known professional was leading a Terriel who, though somewhat plain in head and heary in shoulders, had a very good body and set on of tail, with an excellent coat of good color. When "old George" came to 


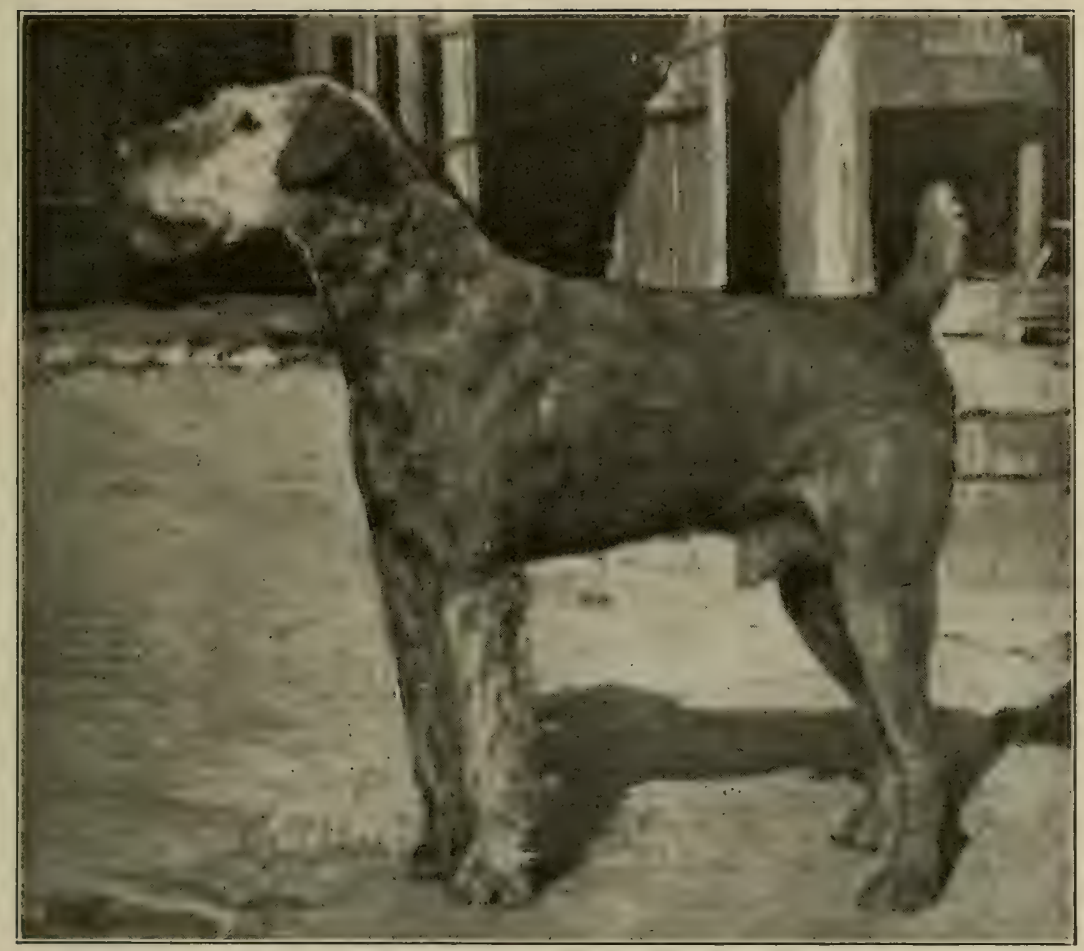

ELRUGE MONARCH

A. K. C.S. B. 144512

Whelped July 1, 1904. By Colne Master Royal ex Clonmel Reseda

Owned by Kootenai Kennels 



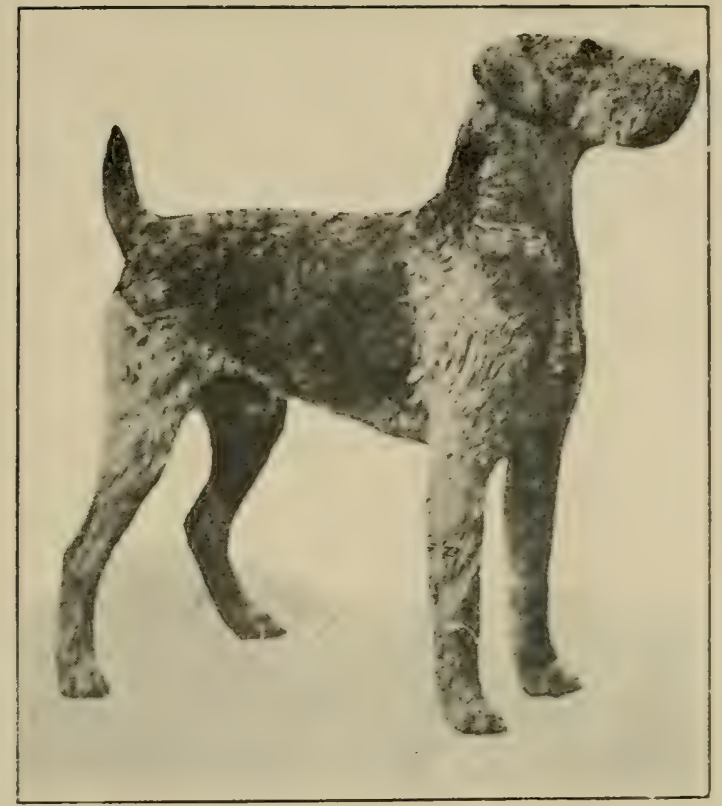

CII. TIIE NORSEMAN

A. K. C... 13. 12199.)

Whelped Nor, 20, $190 \mathrm{~s}$

By Ch. Chorister ex Babs

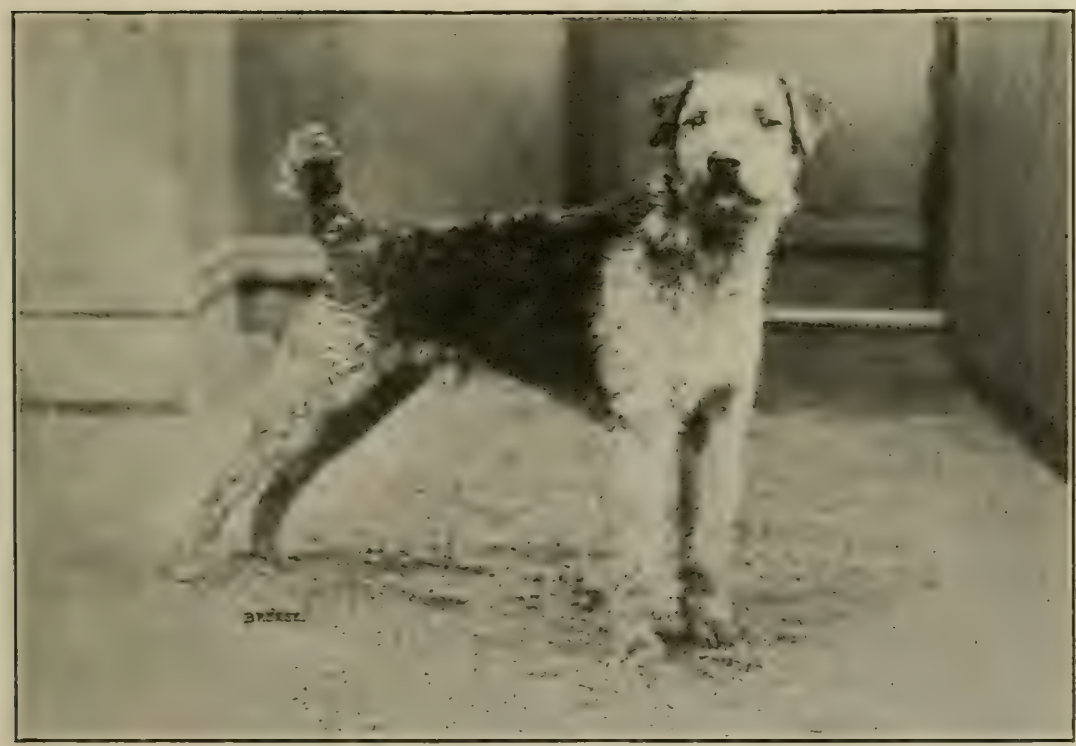

IIOT

A. K. C. S. B. 11746.4

Whelped Dec. 22, 1907. Br Ch. Clonmel Monarch ex Pretty Florrie 
examine this dog. the handlep naturally turned his head away from the judge. and showed him his good hody and outline and his excellent coat. After looking at the dog for a bit, "old George" walked round to have a look at the dog's head and front. when the hamdler immediately turned the dog round again and showed him his hody. etc., again. This occurred two or three times, when "old George" lost his temper and said aloud in his broad Yorkshire dialect, "That 's all right, lad, I 've looked at his body long enough; let 's her a look at his heead nah," and everybody around in the show ring roared with laughter as they appreciated the joke.

A judge usually gives every consideration to the novice, and will give him every opportunity to show his dog. when he is opposed to an experienced, elerer handler; but if the novice has a really good doge it often pays hin to engage a professional handler to take it to the first fin shows till the dog gets thomonghy arenstomed to the show ring. My advice to the youmg fancier is to wateh the best prolessional hamellers when they are showing their own dogs in the ling, and he will soon get hold of the knack. Another hint that I would give the novice is not to push his dog under the judge's nose all the time. or follow him ahout the ring when he is exanining the other dogs; it is not fair to the other competitors, and nothing annoys a judge more. There is no fear that a competent judge will overlook a dog, and he can see the dog much better when it is a short distance from him than he can when it is always under his nose. If he wants to make a closer examination, he will either go to the dog himself or ask the exhibitor to bring it to him.

When taking a puppy on a railway journey to a show, it is better not to give it a heary meal before it starts, or it may be sick in its box and mess itself up. It is far better to wait until it arrives at the show, and then, being slightly hungry, it will eat what it requires.

On returning home, it is a good practice to give it a good dose of Epsom salts, especially if the show lasts more than one day, as it will have lain on the show bench most of the time, and a good clean-out will do it good, and may possibly sare it from an attack of distemper. In any case, it should be kept away from the other puppies for a few days, to see whether it is going to develop distemper or not, as there is always a risk. 



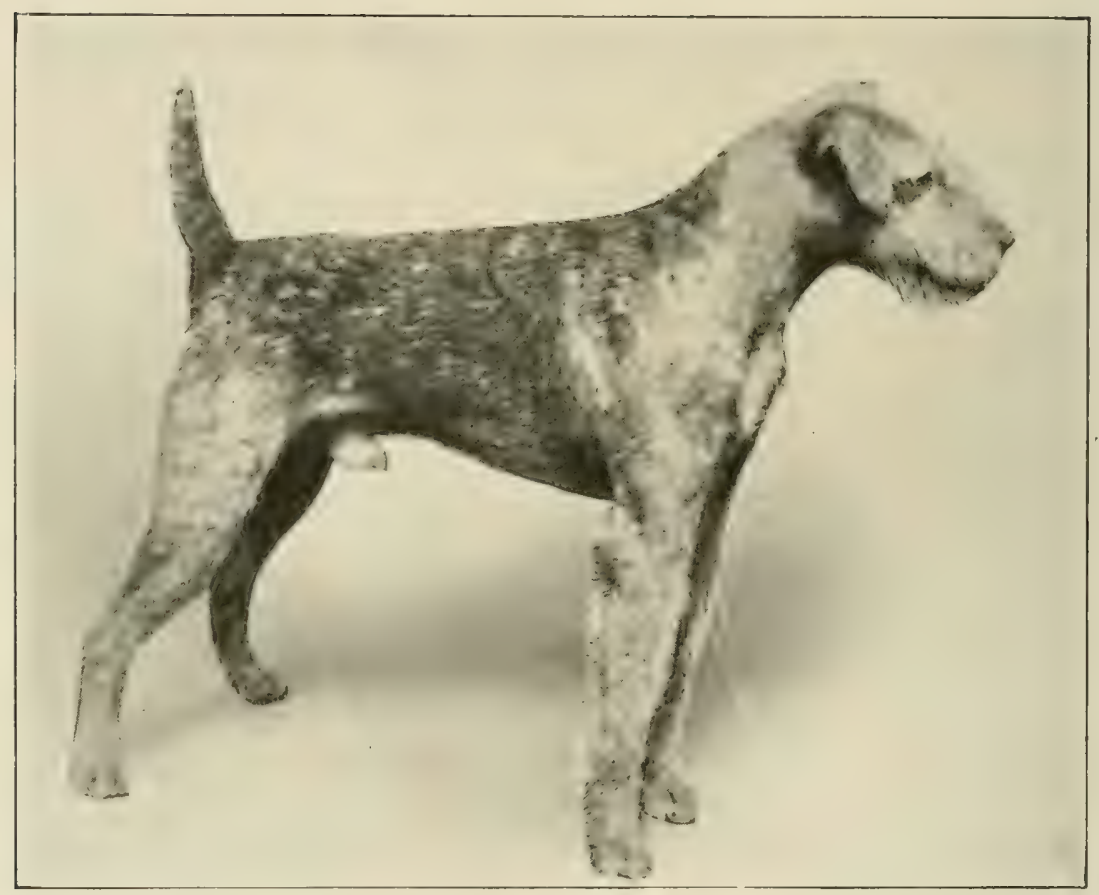

CH. BRIARS MASTERPIECE

A. K. C. S. B. 109,205

Whelped Jan. 1, 1907. By Ch. Bolton Woods Briar ex York Vixen 


\section{CHAPTER VII}

POINTS WHERE IMPROVEMENT IS STILL NEEDED

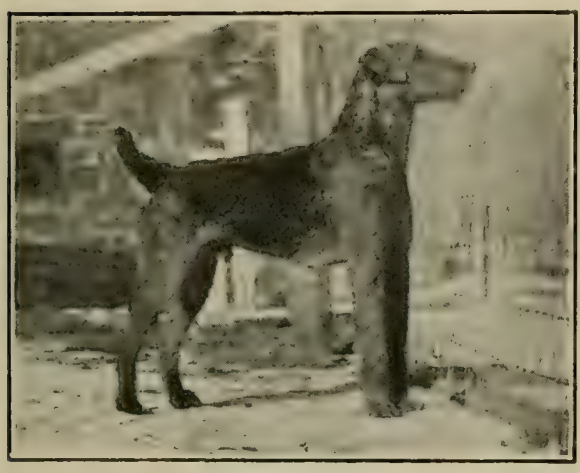

IMPERIOUS OORANG

Although Airedale Terrier breeders are to be congratulated on the wonderful progress that the breed has made in such a comparatively short time, there is still considerable room for further improvement.

There has, no doubt, been a great improvement in heads in recent years, but texture of coat and color have got steadily worse, and I am convinced that many Airedale Terrier breeders are sacrificing the real, hard, natural wiry coat, that it is so essential that the breed should possess, in order to obtain the long clean heads that look so attractive on the show bench. This is a great pity, and if persisted in will do permanent injury to the breed, as nothing disgusts a novice more than to buy a dog who has been trimmed down and appears to have a fairly good coat, and then to find out a few weeks afterwards that he grows a coat like a sheep dog.

The right kind of coat should be so close and dense that the dog should be able to swim across a fair-sized river and back again without wetting his skin at all; and dogs with this kind of coat make the hest show dogs also, as the only preparation their coats require for the show ring is good grooming and the old dead hairs picked out as they appear.

The original and, in my opinion, the best color for an Airedale Terrier is the black saddle and the rich golden tan, which the best dogs of the breed in the past possessed. Champion Cholmondeley Briar, Champion Master Briar, Champion Clonmel Marvel, and Champion Otley Cherin-to mention but a few that occur readily to my mind-were all of this color. It is not only the most attrac- 
tive color, but is, generally speaking, the best for texture as well, and it seldom grows too long. The light-rolored, grizzly-coated ones usually have the worst texture of coat, but these have generally got the longest and cleanest heads.

This reminds me of a curious fact, that has often been commented on hy experienced hreeders of any kind of wire-haired 'Terrier's, and that is, that the best-headed Terriers in any hreed have usually got the worst coats, and the hest coated and colored ones have usually got the worst heads. Why this should be so I do not know; I only know it to be a fact. and I an convinced that all breeds of wire-haired Terriers have a tendeney to come so.

In diredales, as in other hreeds of wire-haired Terriers, the most difficult thing is to get a long culality head, together with a sound, hard, non-trimming eant of good color. They may he hard to get, but when you do get them, if the other points are right, you have a Champion, and it is an ideal worth trying for.

The second point where, in my opinion, considerable improvement is still needed, is in size and sulstance. The diredale Terriers are the biggest of all the Terrier family, and they should have a distinetive chalateter which is all their own. Size, strength, bone and substanee are all essential points it the breed is to maintain its present popularity as all-roumd sporting dogs, and to do the hard, rough work they were first bred for, as it is in these very points that they excel every other breed of 'l'errier.

The fact must not be overlooked that the standard weight of an diredale 'Terrier is to pounds for a ilog, and for bitches slightly less: and personally. I woukd rather have them a pound or two orer this weight, movided that there is mothing ararse or hombly alout them, and that they are full of 'Terrier character.

some rear's ago, the committee of 'The Airedale Terrier Club was so keen on the necessity of maintaining the standard weight of the breed that they adder the following foot-note to the official "Standard of the Airedale Terrier," and it still appears in their Book of Rules. under the official description of the "Standard of the Airedale Terrier": "That it is the unanimous opinion of the A. T. C. that the size of the Airedale T'errier as given in the above Standard, if not the most, is one of the most important characteristics of the breed. All judges who shall henceforth aljudicate on the merits of the Airedale Terrier shall consider undersized specimens of the hreed severely handicapped when competing with dogs of the Stan- 


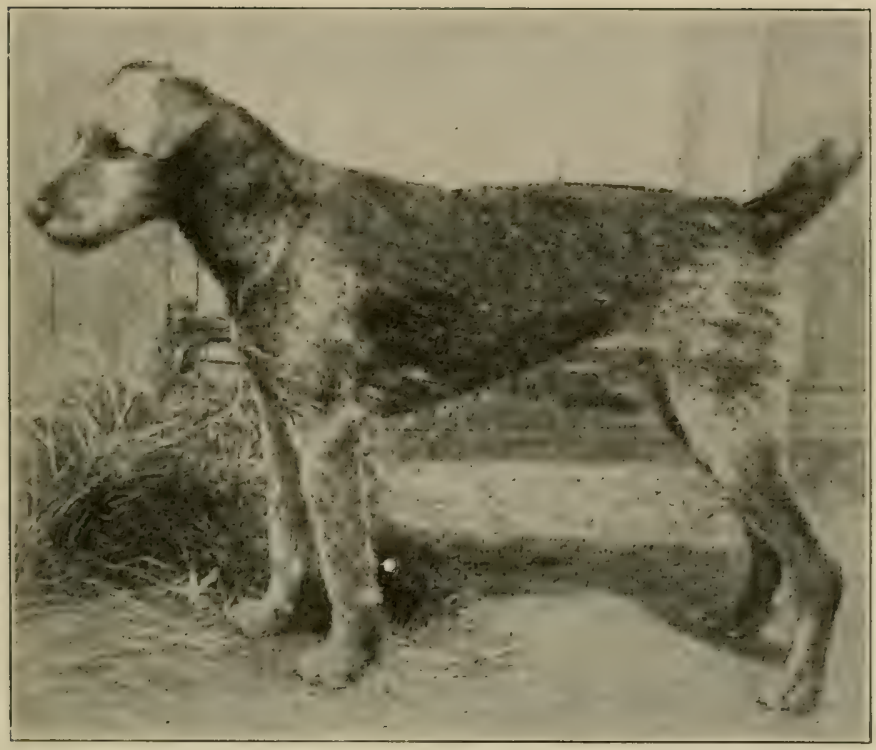

CH. CLONMEL MONARCII

A. K. C. S. B., 61,021

By Ch. Master Briar ex Richmond Peggy 
dard weight; and that any of the Club's Judges who, in the opinion of the Committee, shall give prizes, or otherwise push to the front, dogs of a small trpe, shall be at once struck off from the list of specialist judges."

The first Airedale Terriers that were exhibited, no doubt showed too much of the Otter IIomd, and for many years breeders were trying to get rid of this, and introdure more 'Terrier character': but to-day, in my opinion, there is a danger of this being "arried too far, as we often see smart, showy, good-headed Terriers winning that are light in bone. weedy in body, and under t) pounds in weight: dogs that most certainly could nerere stand the hard, rough work that an Airedale is expected to do.

Fox terriers have to be kept doun to a standard weight to enable them to go to earth to tackle the Fox, Otter or Badger. In the same way, diredale 'Terriers must be kept up) to the standard weight of the breed, if they are to continue to do the work that an Airedale is expected to do.

I hope I have made myself quite clear. What is wanted at the present day is not a hig. coalse, hommly type of 'Terrier, hut a Terlier with the strength, hone, and sulstane and hunting qualities of his ancestor, the ()tter IIomol. combined with the dharacter, quality, gameness and vim of a high-elass 'Terrier'. This may be hard to get, but it is the ideal, and if we keep pegging alway we are sure to get there in the end.

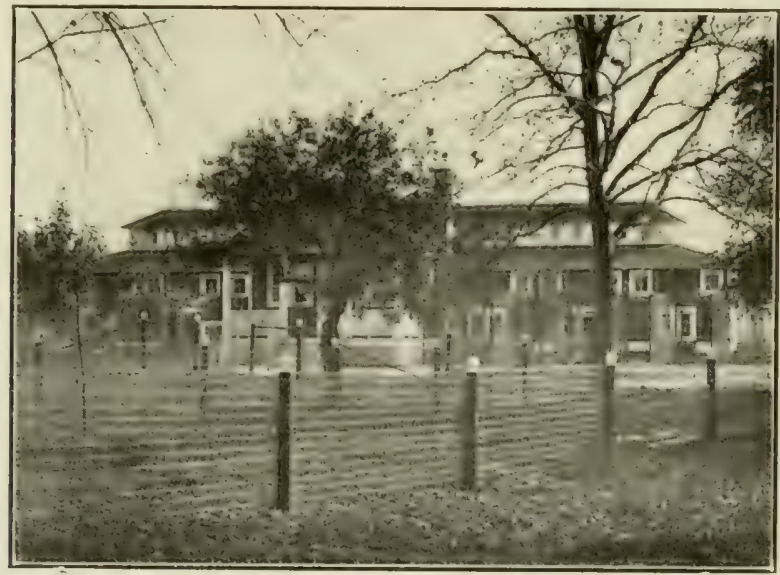

VICKERY KFNNELS 



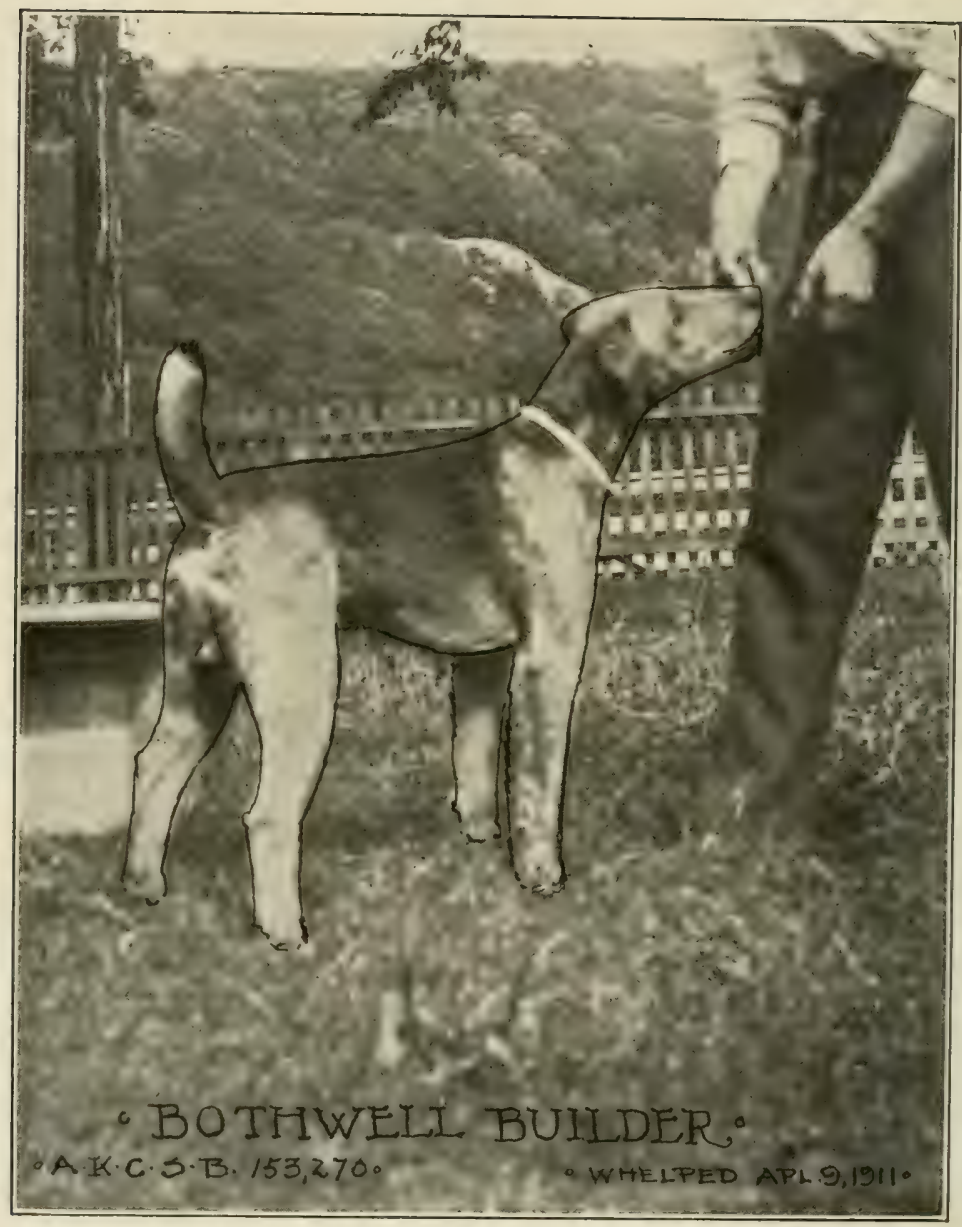

By Ch. Prince of York ex Arnecliff Keno Owned by Arthur B. Proctor 


\section{CHAPTER VIII}

\section{THE VERSATILITY OF THE AIREDALE TERRIER}

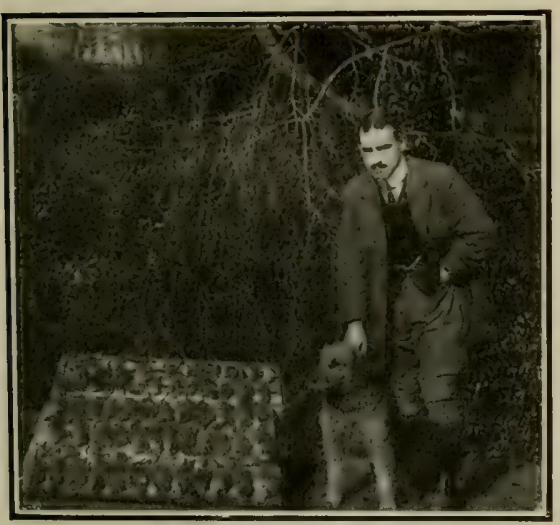

ONE HUNDRED RATS KILLED IN AN HOUR BY AN AIREDALE

The Airedale Terrier is the biggest and hardiest of all the Terrier family, and as an allround, useful dog has no superior.

For the one-dog man who lives in the country, there is no more delightful sporting companion and protector. They are good-tempered and very affectionate, faithful to people they know, and fond of children, who ean romp and play with them without the least danger, as there might be with some breeds that possess the same amount of courage as the Airedale Terrier.

They are splendid guards to either person or property, and if their master likes to go out with a gun, they are in their proper element, as they have a keen, sensitive nose, are born hunters and thorough vermin-killers.

They are excellent water dogs, their close, dense coats permitting them to enter the water at nearly all times of the year, when most other dogs would refuse; are easily trained to retrieve from either land or water, and can be taught to beat game from a rough cover like a spaniel. They have been used to drive both cattle and sheep, and can be taught to hunt the trail of either man or animal.

Though too big to go to ground, they will tackle and hold either an Otter or a Badger; they are exceptionally intelligent and dead game, and have been used for all kinds of sport, in all parts of the world. 
In the United States this dog has been tried and proved his worth in an entirely new fiekl of sport, and from all reports he has taken als naturally to hunting heals as hunting otter, the form of hunting he was bred for.

The eitizens of the western part of the l'nited states and Cimada, where the brown and grizzly bear are plentiful, are loud in singing the praises of the diredale 'Terrien' as they daim he is far superior' to any other breed in use for bear hunting, for he has the strength,

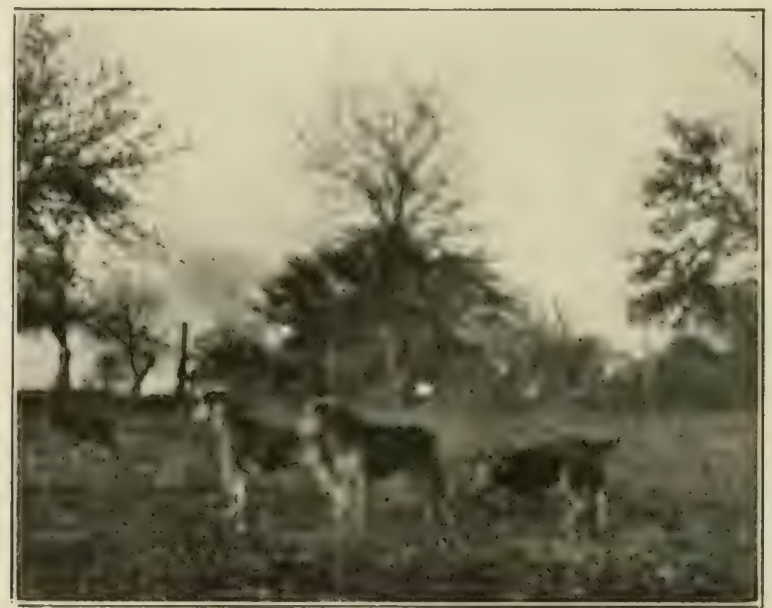

O'TIS AIREIDAES AFIFI,D

the staping powere the gameness and grit of any ofles dog and, what is more to the point. he displays marvelous head work and discretion in tarkling the bear and soon learns the fine points of the game and shows his natural aptitude for it. The only ariticism they ran find in him is that he is a bit too light and does better at this arduous work if weighing from 10 to 20 pounds more tham a "Standard" sperimen, and l understand that they have bred them up to 70 pounds or more for this purpose.

I believe in bear hunting the dog is expeceted to track and engage the bear's attention by worrying hims to give voice and thereby call the hunter to the spot. And the great secret of a successful bear dog is not to get too close to Master Brum's front paws. but just kerep him sufficiently interested to have him remain in one spot long enongh for the hunter to come up and engage him. 


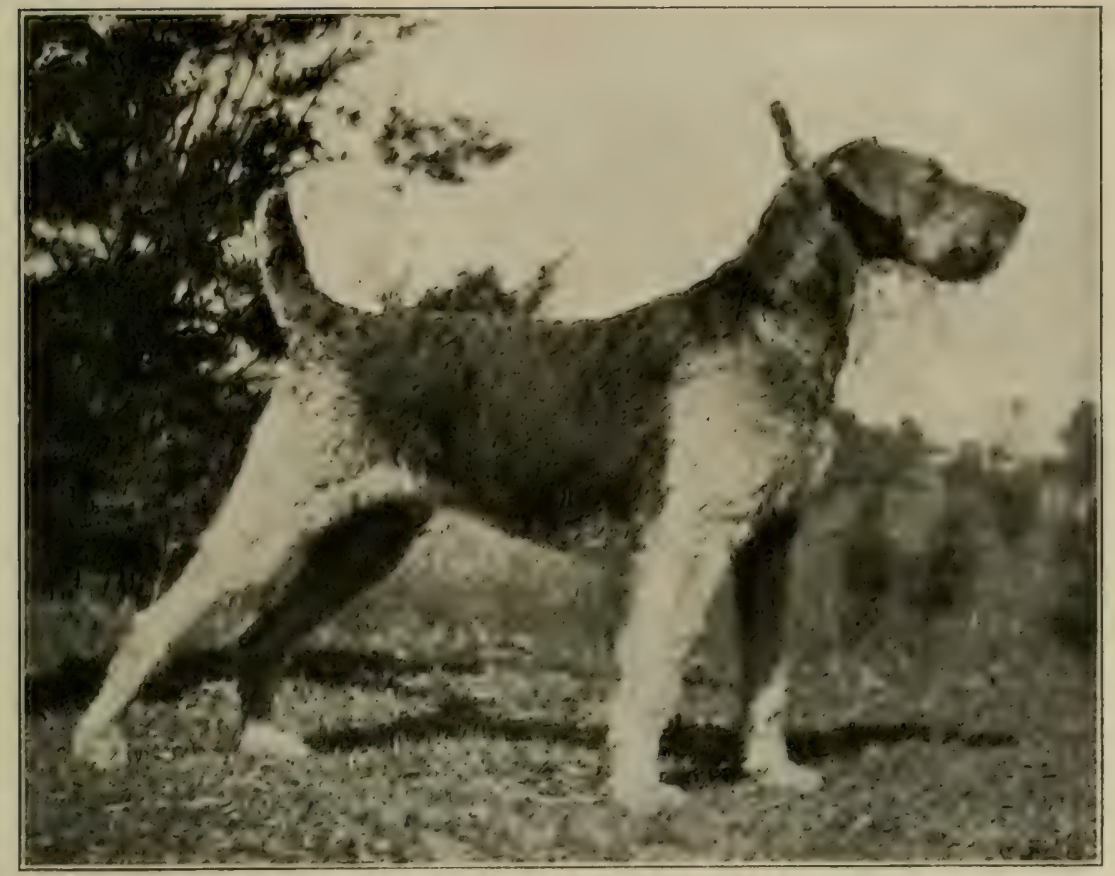

OTIS DIANA

A. K. C.S. B. 14:, $8: 2$

Whelped Feb. 25, 1909. By Otis Lynn ex Royston Naiad 
The hunting is done over very rough country, a great deal of it in the mountains, and a great many miles are covered in a day's sport, and this fact, together with the work expected of him, really calls for a heavier dog than he naturally is.

After repeated experiments with other breeds of dogs, they have become generally adopted as police dogs, both at home and in the Colonial, Indian, and Continental police forces, and are the breed generally used for war purposes in the European armies.

Wherever they have been introduced, they soon make themselves at home, and are general favorites, as they are easily reared and can stand any amount of hard, rough work in either hot or cold climates. They are now firmly established in the country of their birth, the United States, Canada, South America, India, South Africa, Australia, and all over the continent of Europe.

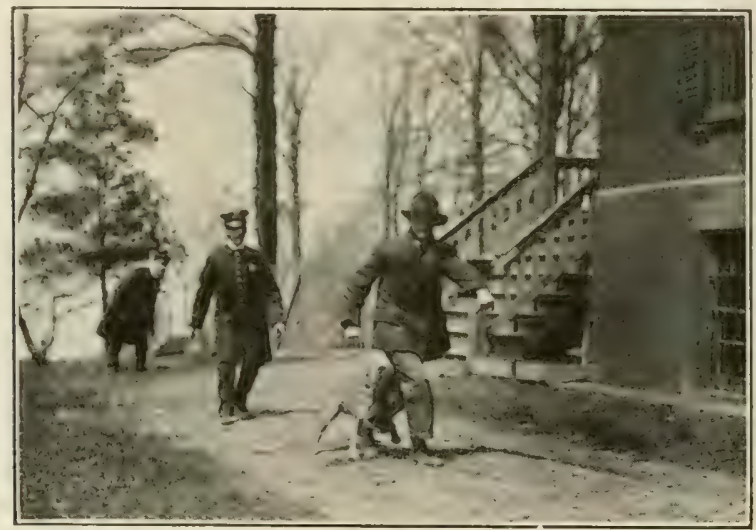

AIREDALES DOING POLICE WORK 


\section{.}




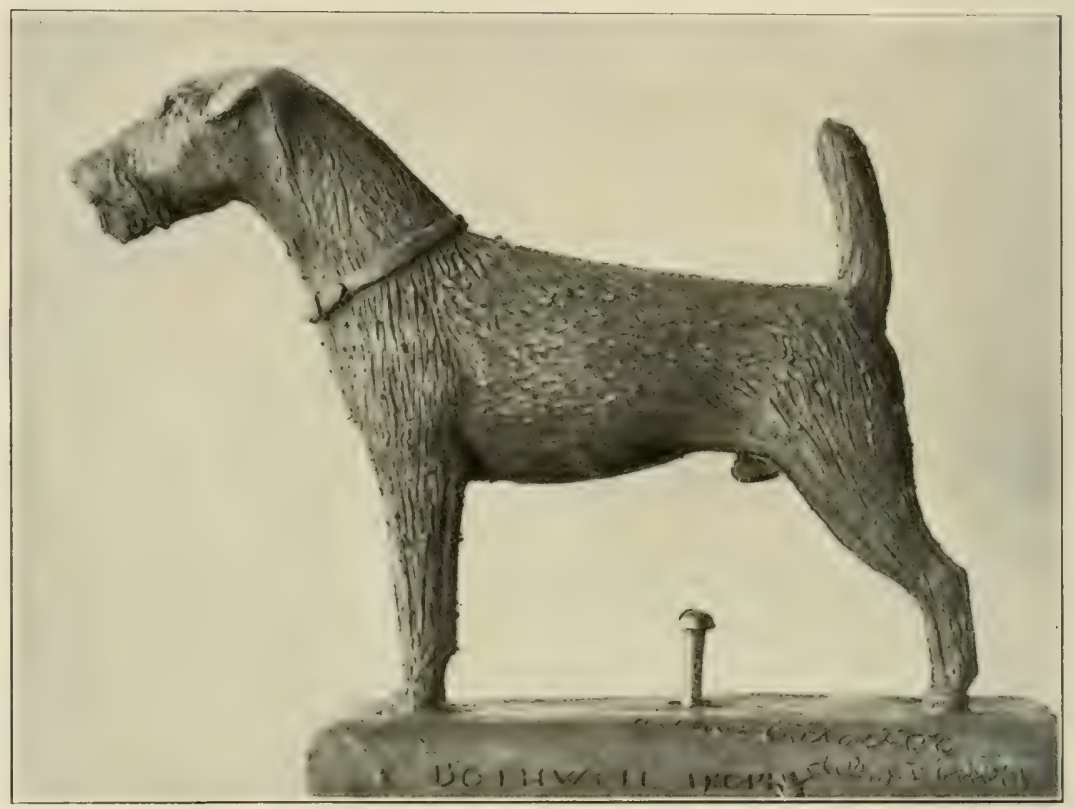

MIODEL OF AN AIREDALE TERRIER

By Arthur Bothwell Proctor 


\section{CHAPTER IX}

DESCRIPTION OF THE IDEAL AIREDALE TERRIER

AND OFFICIAL STANDARD

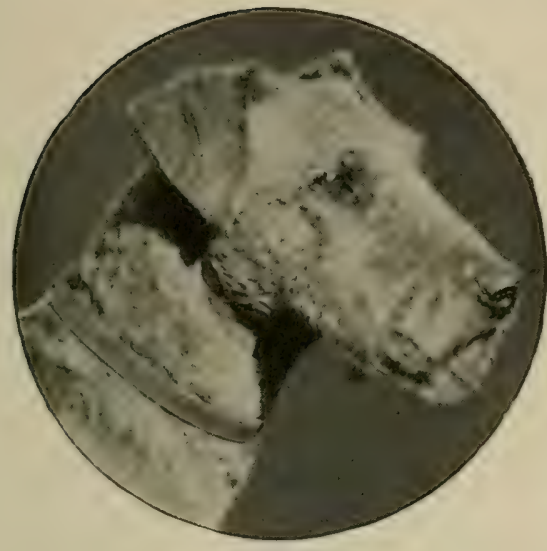

CH. SOUDAN STAMBOUL,

'T'HE ideal Airedale Terrier should be well up to the Standard weight of the breed, which is 45 pounds for dogs and 40 pounds for bitches. The head should be long and clean in cheek, with strong punishing jaws, well covered with broken hair, and flat skull. It should be perfectly balanced, and as long from the occiput to the stop as it is from the stop to the end of the nose. The mouth should be neither undershot nor overshot, and the tecth perfectly level, white and sound. The nose should be black and the eves rather small, dark hazel in color, with a keen Terrier expression; the ears, small, $V$-shaped, and carried close to the side of the head; the neek of good length, widening gradually towards the shoulders and entirely free from throatiness: the shoulders long and fine and sloping well into the back. The legs should he perfectly straight, with plenty of good, round, solid bone and well covered with hair; the feet round and compact, with good thick pads; the coat hard, dense and wiry, moderate in length, and not so long as to hide the outlines of the body, neither wary nor inclined to curl, and without the slightest suspicion of silkiness or linty color; the color black on the saddle and a rich golden tan on the head and legs. The hack should he short, firm and strong, with level top, and the tail set on rather high and carried gaily. The ribs should be well sprung and the chest deep but not broad. The hind quarters, strong and muscular and rather long from the hip to the hock. 
The general impression should be that of a big, sturdy, symmetrical Terrier, with any amount of bone and substance, yet at the same time eutirely free from the slightest suspicion of clumsiness, with a long terrier-like head, small, well-earried ears, dark glossy saddle. and rich golden tan--a dog which combines strength and activity to a very remarkahle degree, ret is full of the highest quality and shows intense Terrier character. He should be game and hard, and full of dash and fire, fit and ready for any kind of sport -in a word, an Airedale Terrier' should look what he really is, both a sportsman and a gentleman.

\section{STANDARD OF THE AIREDALE TERRIER}

UE.1D.--Long, with flat skull, not too broad between the ears and narrowing slightly to the eyes; free from wrinkle. Stop hardly risible, and dheeks free from fullness. Jaw deep and powerful, well filled up hefore the eres; lips tight. Ears V-shaped, with a side carriage: small hut not out of proportion to the size of the dog. The Nose black. The Eyes small and dark in color, not prominent, but full of Terrier expression. The 'Teeth strong and level.

Neck.-Should be of moderate length and thickness, gradually widening towards the shoulders and free from throatiness.

SHoulders AND Chest. - Shoulders long and sloping well into the back; shoulder-blades flat. Chest deep, but not broad.

BoDr.-Back short. strong and straight. Ribs well sprung.

IIIND Qunters._Strong and muscular, with no droop. Hocks well let down. The 'Tail set on high and carried gaily, but not curled over the back.

Legs ANd FeEt. - Legs perfectly straight, with plenty of hone. Feet small and round, with a good depth of pad.

Co.t.- Hard and wiry, and not so long as to appear ragged; it should also lie straight and close, covering the dog well all over the body and legs.

Color. - The head and ears, with the exception of dark markings on each side of skull, should he tan, the ears being of a darker shade than the rest; the legs up to the thighs and elbows being also tan, the body black or dark grizzle.

Size.-Dogs, 40 to 45 pounds weight. Bitches, slightly less. 
That as it is the unanimous opinion of the Club that the size of the Airedale Terrier as given in the above Standard, is one of, if not the most important characteristies of the breed, all judges who shall henceforth adjudicate on the merits of the Airedale Terrier shall consider undersized specimens of the breed severely handicapped when competing with dogs of the standard weight. And that any of the Club's judges who, in the opinion of the committee, shall give prizes or otherwise push to the front dogs of a small type, shall be at once struck off the list of Specialist Judges.

SCALE OF POINTS

Ilead, ears, eyes, mouth

Neck, shoulders and chest

Body

Hind quarters and stern .

Legs and feet

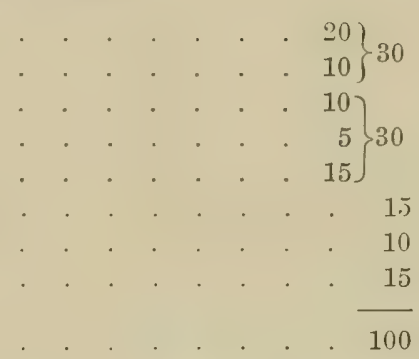

Coat

Color

General character, expression

Total

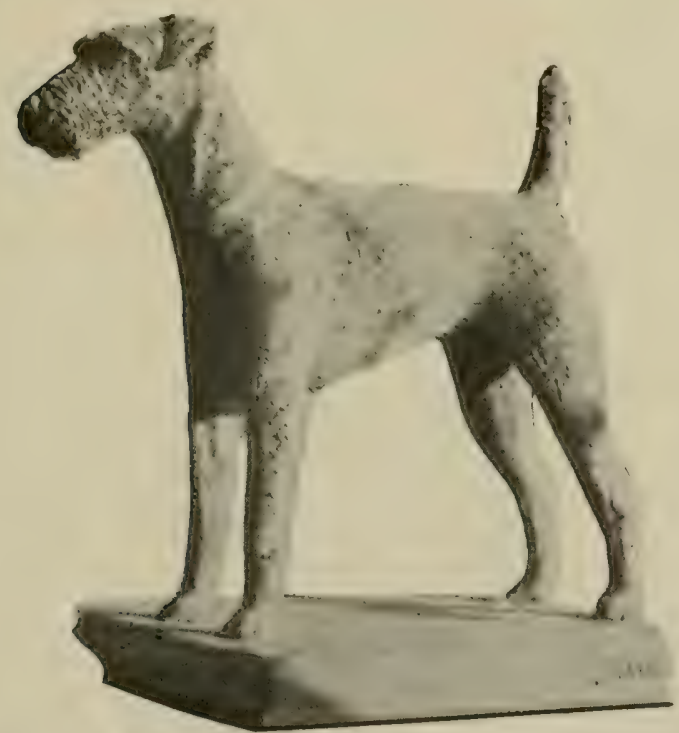

MR. 3. WILLOUGIBY MITCHEL'S MODEL OF AN AIREDALE TERRIER 


\section{JUDGES IN 1911 AND 1912}

AND THE NUMBER OF IVINNERS' POINTS TIIEY IIAVE AIVARIED

\section{C. Ackerman}

Frank H. Addyman

Fisher Ames

G. Muss-Arnolt

E. Altridge .

T. O. Bellin

Carl Bijurman .

IV. L. Barclay

John Bradshaw

John W. Burton

J. C. Bone

J. 'T. Brown

W. E. Baker, Jr.

Geo. Brock .

Geo. A. Cranfield

Ralph D. Condee

. lames Cole.

G. W. Clayton

Thomas Cadwalater

Frank Dole.

Alf. Delmont

Chas. A. Darling

Arehibald Dalby

Erimund Evans

A1. G. Ebberhart

R. O. Forel

Mrs. F. S. Fuller

Phillip French .

Walter G. Glynn
C. G. Hopton . . . . . . 11

C. F. Hochwalt . . . . 15

O. B. Hess . . . . . . . :

Russell Johnson, Jr. . . . . 9

Ur. Harry Jarrett . . . . . 14

B. F. Lewis . . . . . . 2

Edwin Munger . . . . . . 4

Jas. Mortimer . . . . . . : :1

Wm. H. Mulford . . . . . 5

Nat. T. Messer . . . . . . 3

G. Messer . . . . 2

Andrew MeCrea . . . . . 2

John MeGough . . . . . . 3

Theo. Offerman . . . . 7

Walter S. Reeves . . . . 3

D. S. Riker . . . . . 4

Winthrop Rutherford . . . 8

Frank P. Smith . . . . 2

Jas. W. Spring . . . . . 10

A. J. Stewart . . . . .

Geo. A. Thomas . . . 19

.J. R. Thorndike . . . . 9

I. W. Twaite . . . 2

E. W. Thorpe . . . . . 3

F. Taclama . . . . . 2

Edmund J. Tyler . . . . . :3

James Watson . . . . . . 10

IV. H. Whittem . . . . . 2

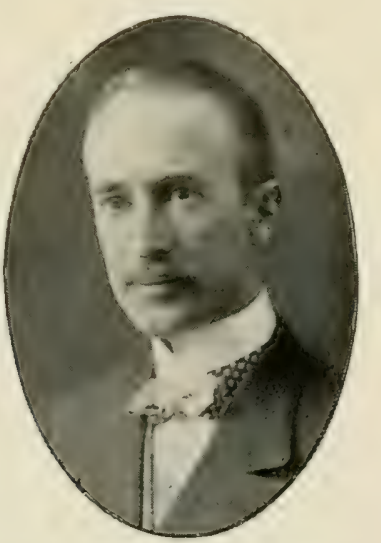

MR. THEO. OFFERMAN

(1) 



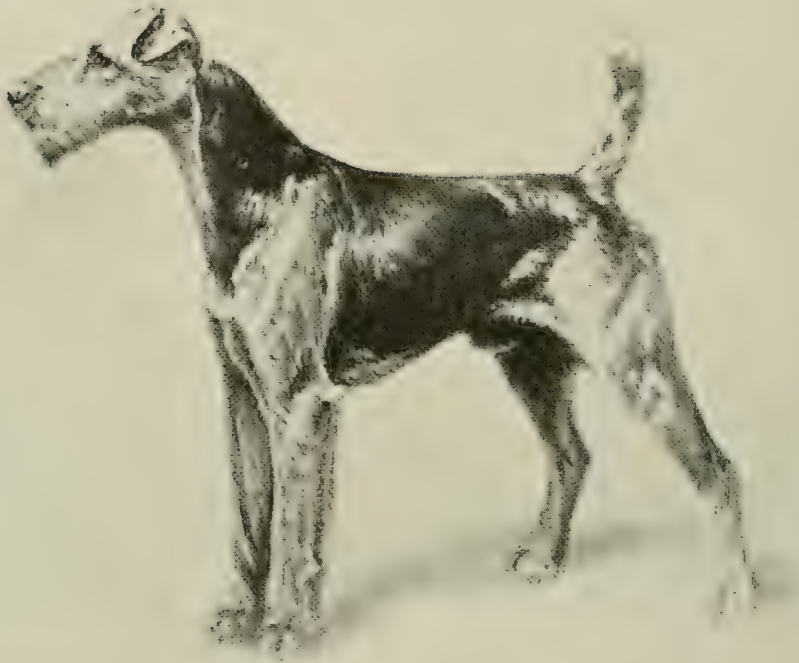

CH. KING OORANG

A. K. C. S. B. 147,494

Whelped June 4, 1909. By Ch. Rockley Oorang ex Cornation Brilliant Owned by Andrew Albright, Jr. 


\section{ENGLISH CHAMPIONS OF RECORD}

ALBAN LASS (407 P) Ch. Freeman Terror ex Alban Belle ARTHINGTON TINNER (1266 C) Willow Nut ex Wandering Lill ASTONISHMENT (441 N) Brownhill Pluto ex Nancy BOLTON WOODS RUSH (381 R) Jack Oorang ex Floss BROADLANDS BASHFUL (1270 C) Briarwood ex Broadlands Burelle BROADLANDS ROYAL DESCENDANT (1667 E) Ch. Clommel Monarch ex Highwood Gipsy.

CHOLMONDELEY BRIAR $(32,967)$ Jerry ex Luce

CLONMEL BED ROCK (1003 F) Ch. Clonmel Monarch ex Highwood Gipsy CLONMEL CHORISTER (323 Q) Primrose King ex Nell

CLONMEL IMPERIOUS (35T R) Ch. Crompton Oorang ex Glamora Princess CLONMEL KING NOBBLER (378 S) Gaelic Hussar ex Gay Flossie CLONMEL KITTY (984 B) Hyndman Briar ex Richmond Peggy CLONMEL MARVEL (985 B) Clipper ex Cholmondeley Mona CLONMEL MIASTER MAGIC (379 S) Ch. Rockley Oorang ex Clonmel Betty CLONMEL MONARCH (355 E) Ch. Master Briar ex Richmond Peggy CROMPTON ALMIDA (1592 J) Crompton Marvel ex Abbey Monarchess CROMPTON OORANG (1591 J) Crompton Marvel ex Abbey Princess CROMPTON PERFORMER (638 L) Ch. Crompton Oorang ex Red Cap Music CULMINGTON NETTLE (562 M) Ch. Crompton Performer ex Bush Lass CULMINGTON VIXEN (445 N) Ch. Crompton Performer ex Bush Lass DANNY GRAIG COMMANDER (311 P) Ch. Crompton Oorang ex Daisy Marvel

DANNY GRAIG KING (971 L) Danny Graig Prince ex Danny Graig Queen DARGLE DEPUTY (382 S) Tintern Desire ex Victoria Madge DELPH GIRL (1251 G) Rock Ferry Bobs ex Ladysmith DUMBARTON LASS (282 A) Sire Unknown ex Colne Pansy DUMBARTON RATTLER (234J) Briarwood ex Susan DUMBARTON SCEPTRE (1261 II) Ch. Tone Masterpiece ex Claverhouse Enchantress

DUMBARTON SUNFLOWER (1262 H) Ch. Rock Salt ex Phillis FELDAY COUNTESS (341 Q) Midland Agrippa ex Lone Bess FELDEN FLOWFR GIRL (633 L) Ch. Master Royal ex Felden Frivolity FERRYHILL FLYER (93 R) Woodman Rival ex Ferryhill Flirt FLORNELL OORANG (223 R) Ch. Rockley Oorang ex Horfield Thistle FREEMAN TERROR (539 M) Crompton Marvel ex hed Cap Music HUCKLEBERRY LASS (1593 J) Crompton Marvel ex Miss Salt ILLUMTNATOR (295 N) Regulator ex Nell KING OORANG (347 Q) Ch. Rockley Oorang ex Cornation Brilliant LANCE CORPORAL SMYTHE (526 M) Elruge Monarch ex Clonmel Britannia 
LEGRAMS PRINCE (104 G) Studholme Spark ex Vexam LEGRAMS PRINCESS (1269 H) The New King ex Cragg House Tixen MASTER BRIAR (1261 B) Briar Test ex Betty MASTER ROYAL $(1271 \mathrm{H})$ Clonmel Chilperic ex Clonmel Loyal MIDLAND ROYAL $(1606 \mathrm{~J})$ Ch. Master Royal ex Madam Briar MISS MASTERPIECE $(1274 \mathrm{H})$ Ch. Tone Masterpiece ex Clonmel St.

Windeline

MISTRESS ROYAL (133 J) Ch. Master Briar ex Claverhouse Enchantress OTLEY CHEVIN (1281 C) Dumbarton Conqueror ex Wandering Lill REBOUND OORANG (397 S) Primrose Rebound ex Preference ROCK FERRY VIXEN (1345 D) Marksman ex Nell ROCK KING (132 J) Ch. Master Briar ex Woodland Judy ROCK SALT (1347 D) Rock Ferry Test ex Marsden Luce ROCKLEY OORANG (452 N) Ch. Crompton Oorang ex Rockley Vesta ROYAL REGENT (1582 J) Clommel Barabbas ex Clonmel St. Windeline SPRINGBANK DIAMOND (455 N) Springbank Performer ex Newfield Sunbeam

SPRINGBANK SUNSHINE (394R) Tintern Desire ex Newfield Ellerslie Vesta

SWEET MOIREEN (682 L) Odsal Crack ex Black Bank Gipsy TINTERN ROYALIST (432 P) Tintern Desire ex Tintern Blossom TONE CHIEF (1609 J) Ch. Tone Masterpiece ex Tone Betty TONE CRACK (1350 D) Tone Grip ex Tone Nut Girl TONE JERRY (1285 C) Jerry II ex Tone Nut Girl TONE MASTERPIECE (1165 E) Ch. Master Briar ex Houston Nell TONE REGENT (1679 F) Ch. Clommel Monarch ex Tone Victoria WATLANDS MARVEL (118 MI) Primrose King ex Primrose Margaret WOODMAN DOLL (49 N) Odsal Bob ex Dolly Varden WROSE BLOSSONI (406 S) Emall Rover ex Laily Guisley 



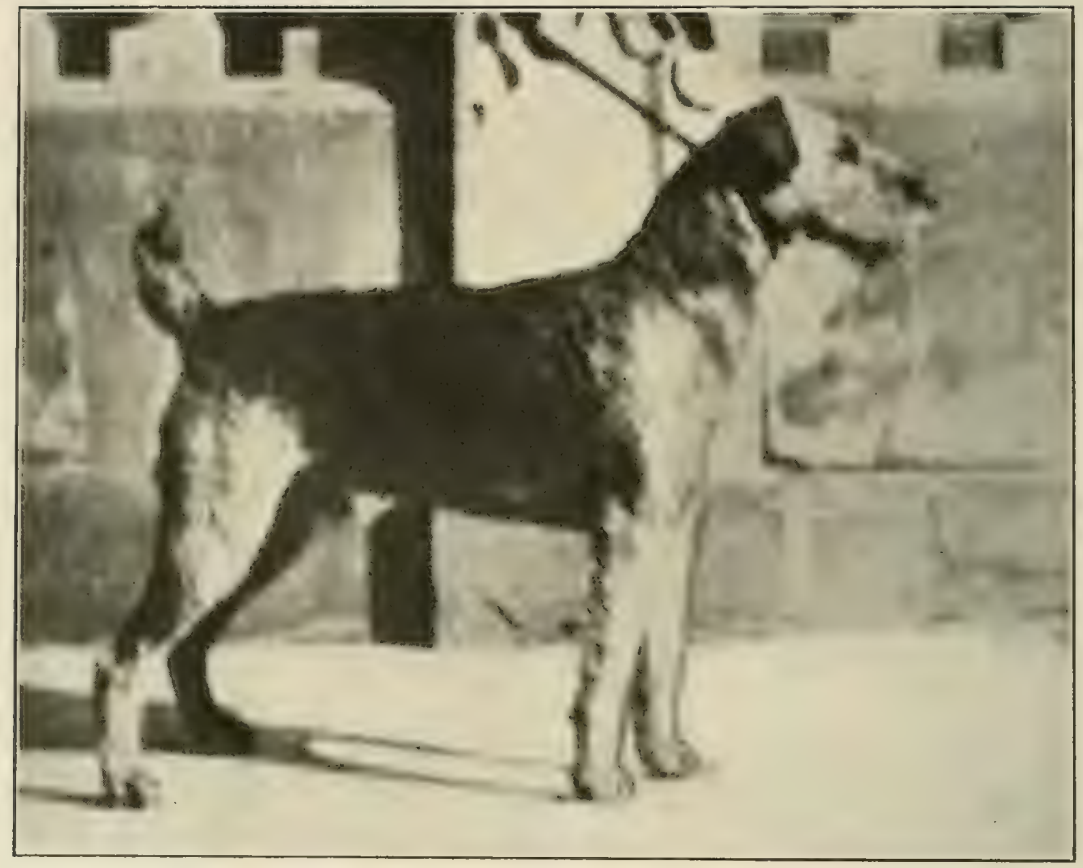

CH. RED RAVEN

A. K. C. S. B. 105,646

Whelped May 31, 1905. By Ch. Clonmel Monareh ex Ch. Red Sunlight 


\section{AMIERICAN CHAMPIONS OF RECORI)}

ABBEY KING NOBBLER (161,928) Soudan Swiveller ex Gay Flossie AIRESHIRE LAD $(110,096)$ Blackburn Trick ex Dumbarton Sunbeam BABS $(121,996)$ Ch. The Gamecock ex Dumbarton Vixen

BARKEREND LILLIAN $(55,695)$ Defiance ex Nell

BOLTON WOODS BLOSSOM $(79,338)$ Odsal Crack ex Studholme Floss BOLTON WOODS BRIAR (76,088) Odsal Crack ex Studholme Floss BRIARS MASTERPIECE (109,205) Ch. Bolton Woods Briar ex York Vixen BUCKS SUNFLOWER $(91,309)$ Ch. Rock Salt ex Dumbarton Mischief CHORISTER $(121,994) \mathrm{Ch}$. The Gamecock ex Ch. Babs ULONMEL BED ROCK (100,376) Ch. Cloumel Monarch ex Clommel Caramel CLONMEL COMMAND $(147,087)$ Ch. Danny Graig Commander ex Kitty CLONMEL CORONATION (100,377) Ch. Cloumel Monarch ex Clonmel Queen CLONMEL ISONOMY $(147,088)$ Ch. Rockley Oorang ex Rose CLONMEL MARVEL $(51,612)$ Clipper ex Cholmondeley Mona CLONMEL MISALLIANCE $(127,076)$ Elruge Monarch ex Clomel Measure CLONMEL MONARCH (61,021) Ch. Master Briar ex Richmond Peggy COLNE LUCKY BALDWIN $(71,660)$ Ch. Master Briar ex Woodland Judy COLNE MASTER ROYAL $(93,908)$ Clonmel Chilperic ex Clonmel Loyal COURTLAND ISABEL $(\mathbf{1 0 4 , 0 1 4 )}$ Royal Challenger ex Nell COURTLAND KITTY (104,015) Ch. Endeliffe Crack ex Endeliffe Glitter DERRYFIELD NELL (120,492) Derryfield Tony ex Derryfield Rose DUMBARTON LASS $(60,636)$ Sire Unknown ex Colne Pansy EL SUR ROSEBEN $(158,917)$ Ch. Thayerdale Tenny ex Thayerdale Sue ENDCLIFFE COMMANDER (175,910) Ch. Crompton Oorang ex Wyuton Lady ENDCLIFFE CRACK $(92,029)$ Watlands Duke ex. Watlands Princess ENDCLIFFE RADIANCE $(112,107)$ Rockferry Conqueror ex Nell Briar ENDCLIFFE VICTORIA (115,116) Wellington King ex Princess Ida FARLEIGH MIKADO (80,680) Crosswicks Dandy ex Crosswicks Beauty FLO $(106,310)$ Culbertson Bramble ex Claybrook Hoyden HARRY JONES $(117,843)$ Ch. Bolton Woods Briar ex Nellie J. HASTINGS CLIPPER $(54,761)$ Clip ex Sweet Briar HASTINGS MONA (54,763) Redstone Briar ex Red Cap HEDGELEY FLARE (131,158) Ingafield Beau ex Fort Hill Bess IHEDGELEY FLASH $(119,486)$ Wyndhill Vandal ex Red Queen HEDGELEY FLICKER (126,501) Wyndhill Vandal ex Wyndhill Jill HIGHGATE KITTY (69,791) Briar Test ex Highgate Puss HrGHGATE KITTY, JR. (107,518) Ch. Endeliffe Crack ex Ch. Highgate

Kitty

INGAFIELD WILD ROSE (116,679) Floriform ex Ingafield Lady

INGAFLORA (98,395) Floriform ex Ingafield Laty 
JUDGE DEXTER $(124,044)$ Ch. Red Raven ex Gamecock Lassie KENMARE SORCERESS (114,241) Resemblance ex Queen Oorang KING OORANG $(147,494)$ Rockley Oorang ex Cornation Brilliant KISMET FLASHLIGHT $(92,661)$ Floriform ex Kismet Kumyss IISMET ROCKFERRI POUNDER $(83,878)$ Rockferry Test ex Rockferry Freeky

KOOTENAI CIIINOOK $(160,417)$ Lakeview Clipstone Prille ex Kootenai

Sweet Lavender

KOOTENAI RADIANCE (137,831) Ch. Matlock Bob ex Ch. Endeliffe Radiance

LADY ALICE $(72,291)$ Nipper ex Waterside Duchess

LADY TEMPEST $(77,183) \mathrm{Ch}$. The New King ex Crown Duchess

LAKE DELL DAMSEL (131,381) Ch. Matlock Bob ex Lake Dell Duchess

LANCROFTE'S DAWN $(154,603)$ Comet ex Wood Blossom

LARCHMERE PITTERSWEET (120,914) Elruge Monarch ex Knotamis IARCHAERE FLASIHWOOD (120,913) Elruge Monarch ex Gipsy Mairen LARCIIMERE MISTRESS MAGNET (135,096) Larchmere Trapper ex Ch. Larchmere Bittersweet

LARCHMERE SURPRISE $(132,934)$ Ch. Lance Corporal Smythe ex Clonmel Challenge

LILLIAN JONES $(117,845)$ Ch. Bolton Woods Briar ex Nellie J. LONG HILL DORIS $(127,317)$ Ch. Red Raven ex Ch. Long Hill Peggy LONG HILL PEGGY (109,178) Ch. Bolton Woods Briar ex York Vixen MATLOCK BOB (117,733) Ch. Midland Royal ex Lady Wilful

MCCONNELL'S QUEEN $(158,312)$ Clommel Rough and Ready ex Brosna

Bacehante

MO'TOR DACE (111,707) Pexcy Dacier II ex Flaims

PILGRIM YELLOW JACKET $(126, \pm 11)$ Ch. Briars Masterpiece ex Pilgrim

Prioress

PRINCE HAL $(85,612)$ Ch. The New King ex Her Majesty

PRINCE OF YORK (141,822) Ch. Crompton Oorang ex Daisy Marvel PRINCESS ROYSTON TESS (103,713) Royston King ex Colne Bell RED RAVEN $(105,646)$ Ch. Clonmel Monareh ex Ch. Red Sunlight RED SUNLIGHT $(99,555)$ Wyndhill Vandal ex Red Queen RIDGECOTE ANTICIPATION (114,097) Dreadnaught ex Luey RIDING MASTER $(122,108)$ Ch. Endeliffe Crack ex Red Riding Hood ROCK PRINCE $(69,790)$ Odsal Crack ex Luce ROWSLEY REGINA (93,991) Wombwell Rattler ex Newlands Lady SANDOWNE DELPH GIRL $(73,252)$ Rockferry Bobs ex Ladysmith SELEL DEBUTANTE (138,586) Strathearn Barkerend Monitor ex Strathearn Nora

SITTING BULL $(119,580)$ Ch. Red Raven ex York Vixen SOUDAN STAMBOUL (151,449) Midland Rollo ex Shaftesbury Queen SOUDAN SWIVELLER $(150,391)$ Elruge Monarch ex Gaelic Beauty SPRINGBANK SCEPTRE (149,988) Ch. Crompton Marvel ex Ellerslie Testa TANGLEWOLD UNA $(115,895)$ Ch. Clonmel Monareh ex Pretty Florrie THAYERDALE TENNY (134,096) Ch. Motor Dace ex Ch. Ingafield Wild Rose 
THE GAMECOCK $(99,702)$ Ch. Clonmel Monarch ex Colne Miracle TIIE MARCHIONESS (104,222) Ch. Clommel Monarch ex Dumbarton Vixen THE NEW KING $(65,826)$ Ch. Rock Salt ex Lucy

THE NORSEMAN $(121,995) \mathrm{Ch}$. Chorister ex Ch. Babs TINTERN ROYALIST $(135,457)$ Tintern Desire ex Tintern Blossom WYNDHILL DIANA $(99,703)$ Ch. The Gamecock ex Blue Gown WYNDHILL TACKLE ( 88,887 ) Crosswicks Dandy ex Crosswicks Beauty WYNTON TYKE $(104,056)$ Colne Tyke ex Otley Madeap WISSAHICKON CHIEF $(122,167)$ Ch. Riding Master ex Lady Nora YORK MASTERPIECE $(80,148)$ Ch. Master Briar ex Houston Nell YORK SCEPTRE $(80,150)$ Ch. Tone Masterpiece ex Claverhouse Enchantress YORK THE CONQUEROR (\$5,935) Wombwell Rattler ex Dumbarton Rose YORK THE HAYMAKER $(124,409)$ Ch. York the Hayseer ex Ch. York Victoria

YORK THE HAYSEED $(93,784)$ Ch. York Masterpiece ex York Sweet Killitare

YORK VICTORIA (81,704). Holy Friar ex Nell

\section{CANADIAN CHAMPIONS OF RECORD}

AUKLAND LUCKY STONE-Ch. Crompton Oorang ex Rockley Belvoureen COLNE TYKE-Ch. Lueky Baldwin ex Colne Mistress

COLUMBUS-Ch. Tone Chief ex Clonmel Dolly CULMINGTON NETTLE-Ch. Crompton Performer ex Bush Lass GRAYSTONE GROWLER-CoIne the Tyke ex Colne Blue Bell KILLARNEY QUEEN-Strathcona Bruce ex Inera Maid KILLARNEY REGENT-Elruge Monarch ex Brosna Bacchante KOOTENAI CHINOOK-Lakeview Clipstone Pride ex Kootenai Sweet

Lavender

LUCKY BALDWIN-Ch. Master Briar ex Woodland Judy WOODHALL BOBS-Tintern Desire ex Golden Lass 
DOGS TAKING WINNERS IN 1911 AND 1912 AND NUMBER OF POINTS WON

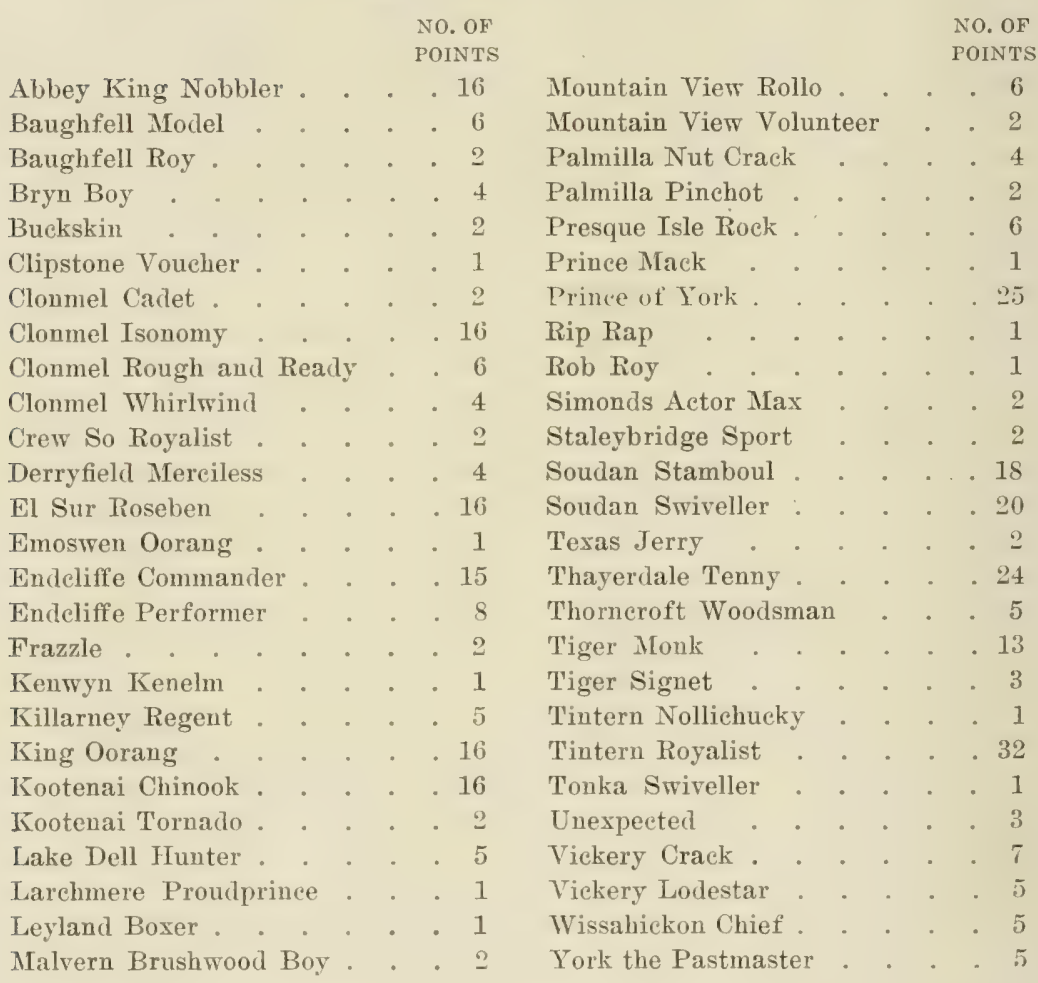




\section{BITCHES TAKING WINNERS IN 1911 AND 1912 AND NUMBER OF POINTS WON}

\begin{tabular}{|c|c|c|c|c|c|c|c|c|}
\hline & & & $\begin{array}{l}\text { NO. OF } \\
\text { POINTS }\end{array}$ & & & & & $\begin{array}{l}\text { NO. OF } \\
\text { POINTS }\end{array}$ \\
\hline aughfell Heather & . & . & . 4 & Larchmere Bittersm & weet & & & . \\
\hline Bess & . & . & 2 & Larchmere Enchant & tress & & & \\
\hline riar Bush & . & . & 1 & Larchmere Mistress & s Mag & gnet & & . 22 \\
\hline it of Fashion. & . & . & 3 & Larchmere Style & & 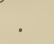 & & \\
\hline rownie Bess. & . & . & 2 & Leeds Elizabeth & & . & & \\
\hline Cero Meto . & . & . & 1 & Leeds Woodblosson & & & & \\
\hline Clipstone Sunbeam & . & . & 2 & Leyland Magnet & 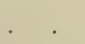 & . & & \\
\hline lonmel Command & 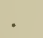 & . & .20 & Ialvern Golightly & & & & 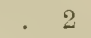 \\
\hline Clonmel Imperious & 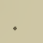 & & . 7 & Monona . & & . & & \\
\hline Clonmel Misalliance & . & & . 21 & Moulin Rouge. & . & . & & \\
\hline lonmel Sonatina & . & . & 3 & awn Pauline & & & & \\
\hline Clonmel Sweet Lass & . & . & . 1 & Otis Diana. . & & & & \\
\hline Colne Model Queen & - & . & . 2 & Our Queen . & 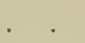 & . & & . 12 \\
\hline 1orne Miss Eliza & . & . & 2 & Palmellia Princess & & & & \\
\hline on Kite & 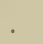 & . & . 6 & us Nancy & & & & \\
\hline e Minx & & . & . 3 & on $T$ & Tess & 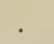 & & \\
\hline . & & . & . 9 & Is Lady Ball & lochmy & & & \\
\hline ere Rowena. & • & & . 1 & ssie G. & 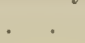 & & & \\
\hline -Lancrof & $\mathrm{fts}$ & Dawn & 18 & an Sapphire & . & . & & \\
\hline perry Hayden & & & 2 & Soudan Soo & . & s. & & \\
\hline oan & . & . & . 2 & Springbank Sceptre & & . & & 15 \\
\hline e Roy. & . & . & 1 & Id Tauntr & ress & & & \\
\hline e Jones & & 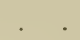 & 4 & Id Una & & & & \\
\hline yn Bristles & & . & 5 & Jingle I & Bell & & & \\
\hline n Discreet & & . & 2 & & & . & & 12 \\
\hline rney Queen & & & 7 & n Marjorie & & & & \\
\hline Kootenai Dolly & & & 2 & y Capacity & 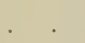 & . & & \\
\hline nai Radiance & & . & .15 & rette. & . & . & & \\
\hline enai Siroceo. & & & 7 & ry Vesta. & . & . & & 13 \\
\hline Lady Oney . . & . & & 1 & Victoria & & & & \\
\hline Lake Dell Damsel . & & & .11 & ds Jessie & & $\cdot$ & & \\
\hline Lake Dell Racket. & 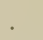 & & . 5 & Willovale Bit of $\mathrm{Fa}$ & ashion & & & \\
\hline
\end{tabular}




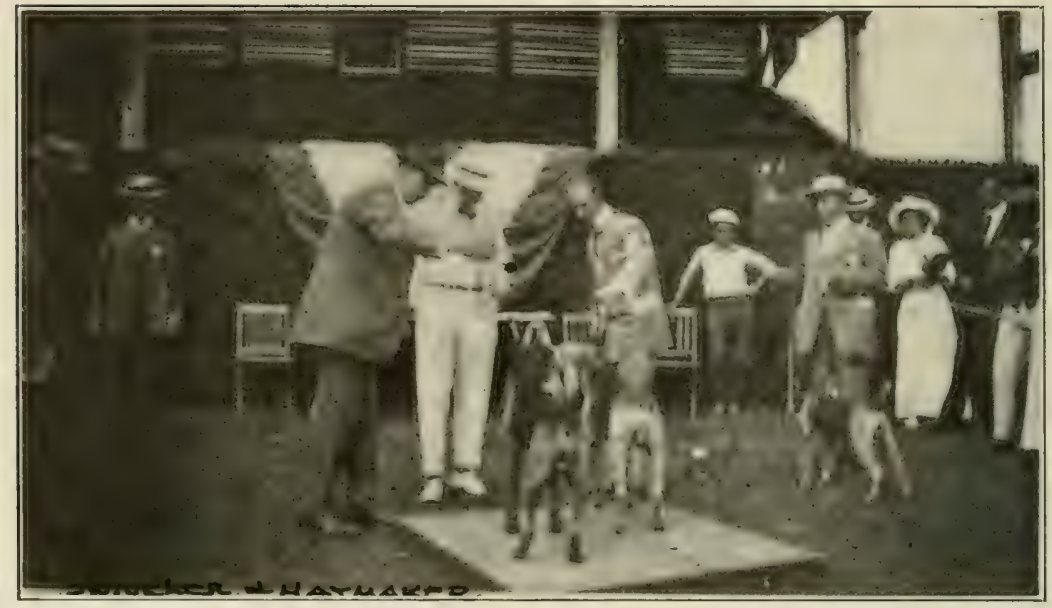

MR. JAS. W. SPRING JUDGING AIREDAIES A T LONG BRANCH, 1911

Mr. Offerman showing Haymaker against Swiveller in Winners' Class 
BREEDERS AND THE BREED

IN AMIERICA 


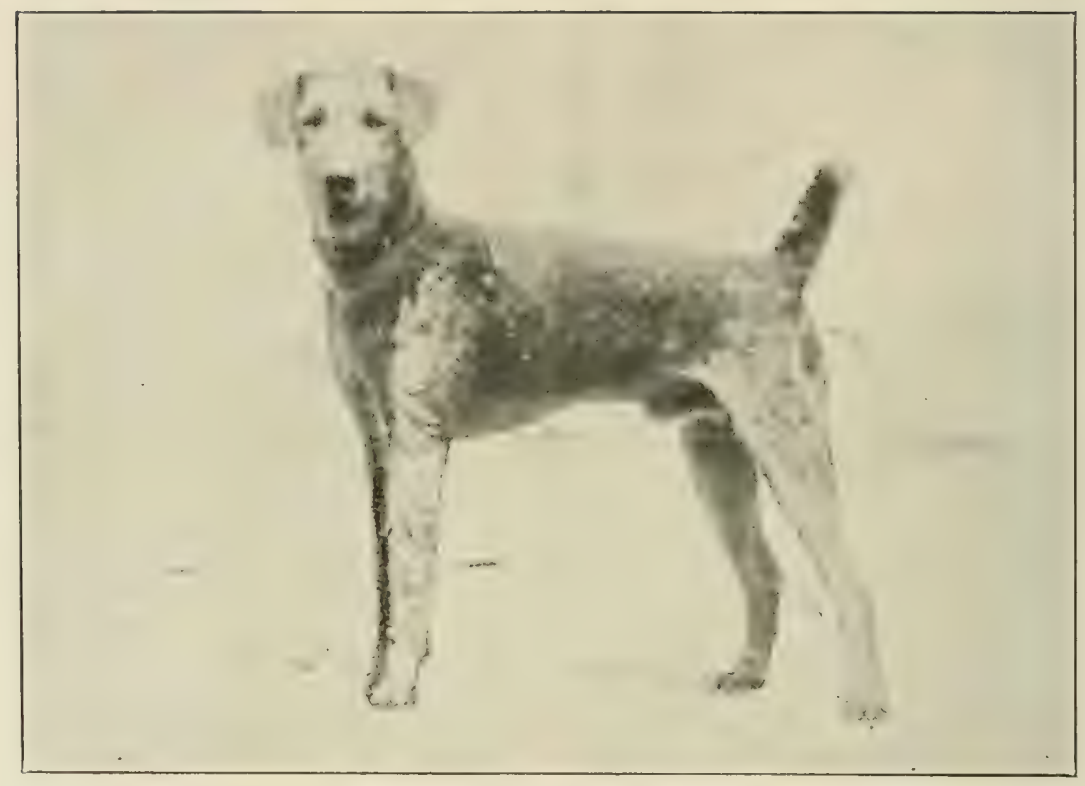

VTCKERY LODESTAR

A. K. C. S. B. $156,18:$

Whelped July 25, 1911. By Ch. Tintern Royalist ex Ch. Larchmere Nistress Magnet

Owned by Vickery Kennels 


\title{
BREEDERS AND THE BREED IN AMERICA
}

\author{
BY ARTHUR BOTHWELL PROCTOR
}

'TuE Airedale Terrier is one that has shown, from the first realization of his sterling worth, a rapid gain in popularity, and the breed is now, both in point of numbers and popularity, easily the first of all the Terriers.

'This is as it should be, for I think it fair to say, without undue bias, that a greater all-round $\log$ does not exist; one who is first of all a real pal and an ideal children's companion, a watch-dog without equal, with unusual discretion, generally good-natured under extreme provocation with both man and heast, but game to the core when aroused; a natural-trained vermin destroyer and hunter; in fact, the bcau idcal of a gentleman's dog in a country place, or a farmer's pal and house protector.

The Airedale 'Terrier generally is conceded to liave been first imported about the year 1880, and the first dog shown was one named Bruce, owned by Mr. Mason, and we believe the next in the field was Mr. Harry Lacy, who showed two in 1881.

Little, if any, activity in the breed was shown and no classes were given for this 'Terrier until the New York Show of 1898, when IIr. J. Lorillard Arden (who, amongst others, imported and owned C'lonmel Marvel, Clonmel Veracity, and Rockferry Pounder) entered the field, quickly followed by Mr. A. De Witt Cochrane with Barkerend Lillian, Clipper, and Hastings Mona; Mr. P. Mallorie and Mr. J. IIopkinson with Rustic Jill and Broadlands Brushwood; Mr. Silas Wodell, Mr. J. Carver and Mr. W. S. Todd with Ryecroft Jennie, and Mr. Wm. C. Hill with Ainsflyer Deputy.

Then, in 1900 and 1901, the nominations of Mr. Clement Newbold, Briar Vampire, Broadlands Bilbury and Clonmel Monareh, were imported, and through the last-named dog, who created a sensation at that time and could probably worry the best to-day, an interest was aroused in Philadelphia and vicinity that has never abated. 


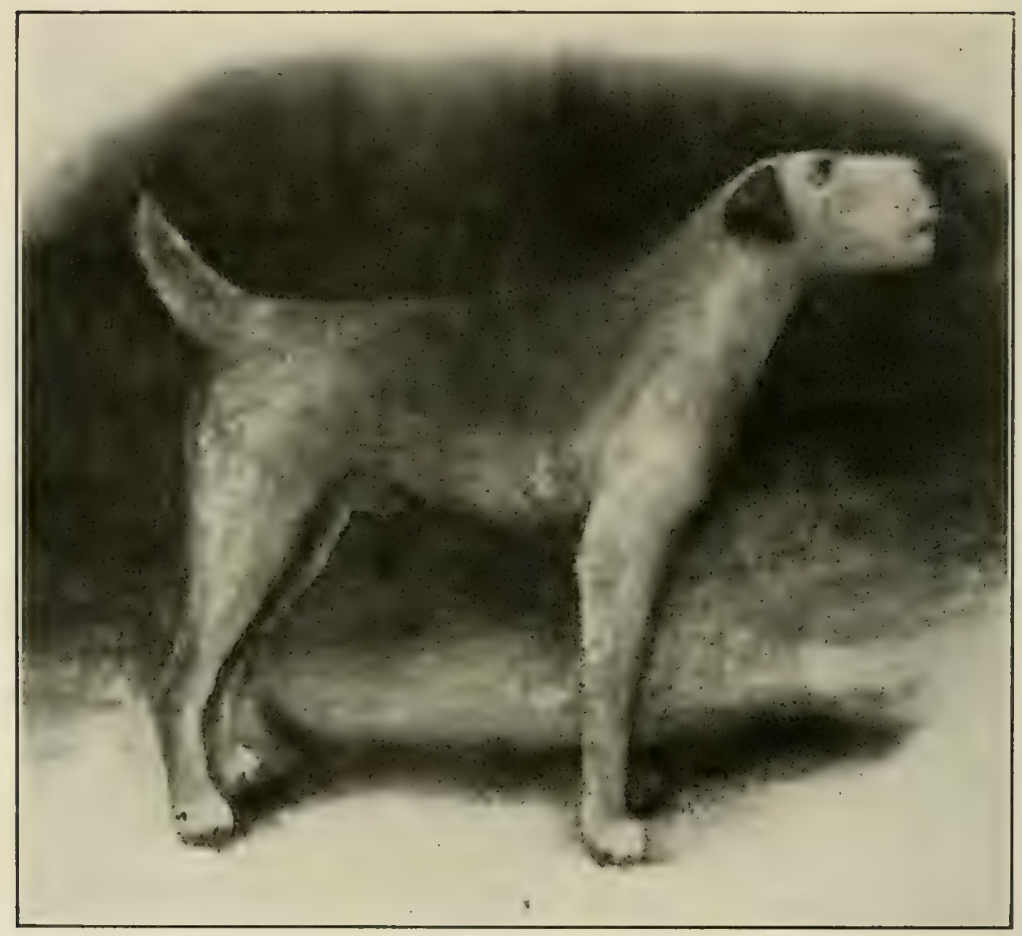

CH. BOLTON WOODS BRIAR

A. K. C. S. B. 76,088

By Odsal Crack ex Studholme Floss 
Monarch produced many champions and first prize winners, did an immense amount of good at stud, and his blood is the backbone of the Philadelphia strains of to-day, and through the bitch side is particularly good blood in a pedigree. Champion Farleigh Mikado, by Crosswicks Dandy, was probably the best Mr. Newbold bred.

About this time Mr. Russell Johnson imported Hastings Duster, a bitch who did quite a bit of winning and produced some good stock. He afterwards brought out Red Hackle and Champion Red Sunlight, and in 1907 bred Red Raven, who was himself a splendid producer.

Very shortly after, "The Sage of Chestnut Hill," Mr. William S. Barclay; Mr. Albert Harker, and Mr. Thos. Cadwalader took on the breed, followed by Mr. Lynford Biddle and Mr. W. H. Whittem.

Mr. Barclay bred Champion Wyndhill Tackle and Champion the Gamecock, and I think Wyndhill Vandal, who sired three Champions, though not reaching that pinnacle himself, and his enthusiasm is as great to-day as when he first started, and he has done much to foster interest in the breed in Philadelphia and vicinity.

Mr. Lynford Biddle got a biteh by Master Briar from Dr. Jarrett, named Dumbarton Vixen, a real good one herself, from whom came Champion Babs; she in turn, bred to Ch. The Gamecock, produced Ch. Chorister, and bred to Chorister, produced Ch. The Norseman, one of the best American-breds of any time. Vixen, when bred to Ch. Clonmel Monareh, produced Ch. the Marchioness.

IIr. Cadwalader, with Choir Girl, a litter mate of Chorister, and bred to Jack, a litter brother to Babs, produced Chorus Girl, who was a winner and producer of winners in each litter, and who, mated to Kilearn Oorang, produced Cactus, a recent winner.

Of the more recent entrants around Philadelphia, Mr. Wm. H. Mulford, Mr. Joseph Sims and Mr. Andrew McCrea, the first mentioned, with the kennel name of Hedgeley, has brought out Chs. Hedgeley Flare, Flash and Flicker, and the more recent winner, Abbey Sultana.

Mr. Foxhall Keene, with Chs. Clonmel Bed Rock and Clonmel Coronation, and Mr. 'Theodore Offerman were among the first New Yorkers to get into the game, and the last named, with the prefix of "York," has done and is doing his best to keep the interest in the breed at a fever heat. The first dog he brought over was Clonmel Floriform in 1904, and, amongst others, he has imported Ch. York Sceptre, Ch. York Masterpiece, Areadia, Ch. Bolton Woods 
Briar, Ch. York the Conqueror and Ch. Prince of York. A few of his breeding are Ch. York the Inayseed, hy Masterpiece; Ch. York the Haymaker, who, no longer a roungster, can make the hest of them hustle to-day, he being by The IIayseed out of Ch. York Victoria, and his latest home-bred, York The Past Master, by Isonomy, the puppy who took winners at New Tork last year. Mr. Offerman is ever ready with advice or assistance to the novice, is a liberal supporter of the shows, and one of the most able amateur judges.

MIr. J. II. Brookfield, with Kismet Rockferry Pounder and Ch. Kismet Flashlight: Mr. Perry Tiffany; Mr. W. S. MeCoomb, with Rowsley Sultan and Regina; and Mr. E. S. Woodward, with Delph Girl and Tone Tackler, were all of about this second period.

In the period between 1902 and 1905, Mr. .John McGough (who owned Ch. Bolton Woods Briar, Ch. Harry Jones, Incle Sam, Lady Mary and Goldheels, all but the first being home-bred)

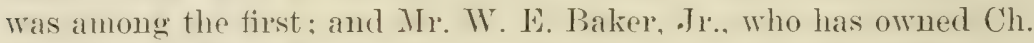
Tanglewold Tna, Pretty Florrie, Brosna Bacchante, and Tanglewold Briar Test; Mr's. MI. E. Gates, Jr.., with Ch. Lilliau Jones; Mr. Jemnings, with Rough and Tumble and 'Tintern Marjorie; and Tessrs. Bumnell and Boorum, of the Burnley Kennels, all entered the game about the same time.

Mr. Andrew Albright, Jr., with such terriers as Ch. Tintern Royalist and ('h. King Oorang. and such bitches as Banghfell Heather and Baughfell Scentre: Mrr. John Nurray, who bred Ch. Brials Masterpiece and Ch. Long IIill Peggy, and owned York Vixen. the dam of both these terriers; Mr. Edmund Evans, who owned that good American-hred IIot: Mr. S. C. Denly, with Ch, the Marchioness and Tanglewold Briar 'Test: Mr. A. B. Dalby, with Long IIill IDoris: and Miss ('atherine ('ameron were the most prominent amongst the breeders and exhibitors at this time.

In the last seven years most of the above have remained actively in the gane, and Mr. Daniel liker, with .John Harvard; Mr. J. N. R. Bryant, with ('h. Tanglewold Lna; Mr. R. P. Oreutt : and Mr. Howard Ehrich, with Ch. Lancrofte Dawn, are among the more recent recruits. And still later, the late Mr. Geo. Batson (who, with Mr. Offerman, imported Ch. Prince of Tork and Ch. Soudan Sapphire, and afterwards, alone, brought over ('h. Soudan Swiveller and Ch. Soudan Stamboul) made a place and name for himself in the fancy, and did much to boom the breed he thought so much of.

The "Down Easters" were ably represented by Mrr. Arthur 
Merritt, with the kennel name of Hastings, who imported Dumbarton Ranger, Clonmel Majesty, Ch. the New King and others, and bred that good terrier Ch. Prince Hal; $\mathrm{Mr}$. Philip French, with Amazement; Mr. Robert Jordan, with Lance Corporal Smythe, Ch. Larchmere Bittersweet, Ch. Larehmere Mistress Magnet and Larchmere Proudprince; Mr. Geo. West, with the prefix of Gamecock; $\mathrm{Mr}$. Fisher Ames, with Ch. Pilgrim Yellow Jacket; Mr. Jas. W. Spring and Mr. Jas. T. Leyland.

Last but not least come the Kemmare Kennels, owned by Mr. William Prescott Wolcott, containing Ch. Soudan Swiveller, Ch. Soudan Stamboul, Ch. Kenmare Sorceress, Ch. Princess Royston Tess, Soudan Sapphire (Ch. Springbank Diamond in England), and the American-bred bitch Bothwell Sorceress, a daughter of Ch. Kenmare Sorceress, in all a team hard to duplicate.

Going over the long list of names of other breeders of the early days, one comes across Mr. Matthew Morgan, with Acrington Crack; Mr. Monson Morris, with Clonmel Bed Rock and Coronation; $\mathrm{Mr}$. J. H. Brookfield, with the Kismet strain; Mr. John Walton, with Dumbarton Ranger and Lord Raglan; Mrr. Daniel Buckley, of Clipsdale fame, with Bronside Monarch and Bolton Woods Blossom; Mr. W. J. Burgess, with Rustic Teddy and Royston King; Dr. Jarrett, with Dumbarton Vixen; and others.

The West did not start to join the fancy until after the East was well started, but in enthusiasm, as in point of numbers, they certainly have the palm to-day, and if the great majority of the far Westerners do not breed more dogs that come up to Eastern standards, it is because their interest in this breed leans to the utility side of the Airedale rather than to the show side.

IIr. Earle J. Woodward, of Chicago, was one of the first to take on the breed; and Mrr. Ralpl Condee with Tiger MIonk, Mr. Edwin A. Nunger, Mr. Elbridge Haney, Mr. Francis G. Porter, Mrrs. Crawford and C. H. Perrin, the last two showing under the kennel name of Vickery, are the leaders around about Chicago.

The rivalry between $\mathrm{Mr}$. Porter's kennels, containing, amongst others, Champion Freeman Terror, Ch. Clonmel Isonomy, Ch. Abbey King Nobbler, Abbey Master Nagic, Unexpected, Ch. Springbank Sceptre, Ch. Clommel Command, and Ch. Clommel Imperious, and the Yickery Kennels, who have C'h. Prince of York, Ch. Tintern Royalist, Ch. Larehmere Mistress Magnet, Tickery Vesta, and that sterling son of Royalist, Vickery Lodestar, is intense, and they are 


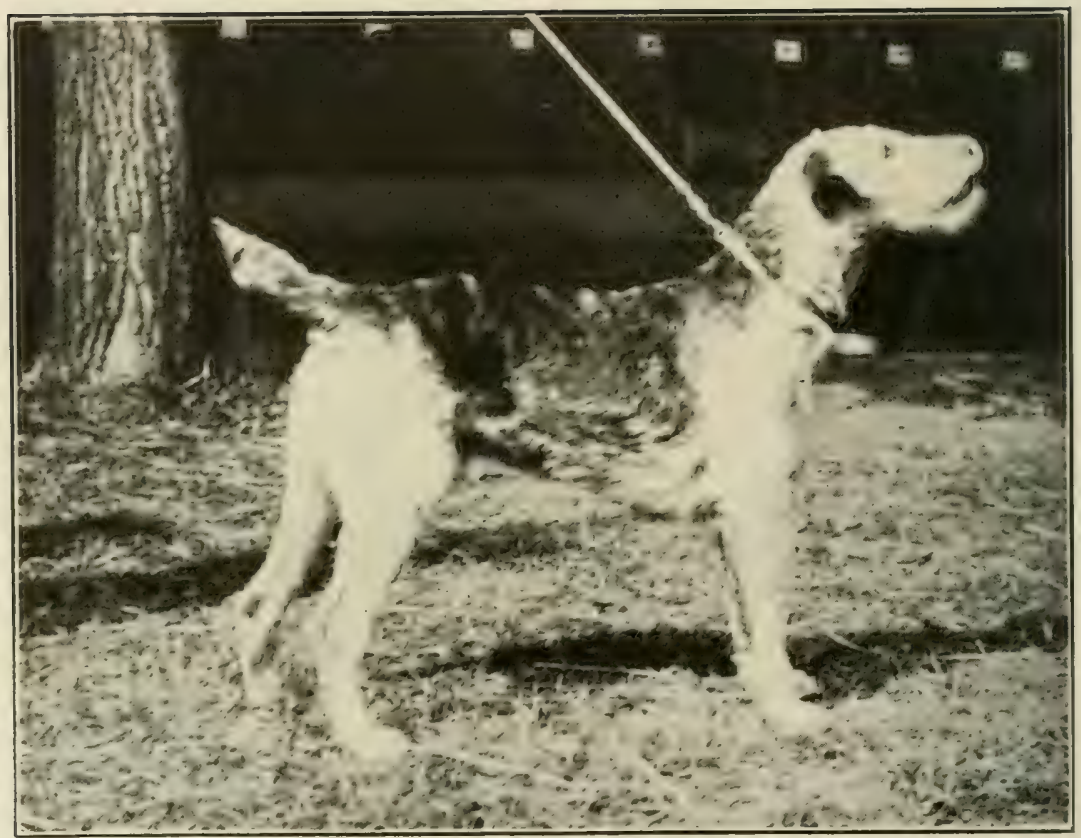

CH. PLLGRIM YELLOW JACKET

A. K. C. S. B. 126,411

Whelped April 25, 1908. By Briars Masterpiece ex Pilgrim Prioress 
ever vying with each other to purchase a better one, and both kennels by their liberal purchases have done much to further the best interests of the breed.

In the far West, Mr. R. M. Palmer, owner, among others, of Ch. Matlock Bob and Ch. Lake Dell Damsel, was probably one of the first breeders, and gets good competition when he meets $\mathrm{MIr}$. Geo. F. Downer's dogs and bitches. The last-named gentleman, who comes from Montana, has bred Ch. Kootenai Radiance and Kootenai Chinook, and has just headed his kennel with Elruge Monareh, that famous sire of Champions who has been lost to breeders through his inaccessibility.

Mr. Downer finds a rival in the same town in Mr. Jas. G. Keefe, of Mountain View fame; and going over the very long list of names of breeders of the far West, one comes across Mr. Chas. P. Rockwood, owner of the American-bred bitch Otis Diana; Mr. F. S. Dennison. of the Chief Kemnels; Mr. Wm. Timmerman; and Dr. H. V. Addix, who has just purchased that famous American-bred Terrier Ch. Red Raven; while in California $\mathrm{Mr}$. J. A. Folger, Mr. Nat. T. Messer, who bred Ch. Thayerdale Tenny, and Dr. Toney are among the ardent supporters of this good Terrier.

Canada has always been most ably represented in Mr. Jos. Laurin, and the prefix "Colne" is known wherever the Airedale Terrier is known and shown. A few of his importations are Ch. Dumbarton Lass, ('olne Lucky Baldwin, Ch. Naster Royal, Ch. Mistress Royal, Ch. Freeman Terror, and Ch. Rockley Oorang-all names to conjure with both at stud and in the show ring.

Mr. Jas. W. Baine; Mr. Joseph Perkins; Mr. Bert Swann; Mr. McConnell, owner of Ch. MeConnell's Queen; Mr. E. W. Thorp, with Clipstone Sunbeam; Mr. C. Cobb, with Marshall Tinner; $\mathrm{MIr}$. J. F. H. Usher, with ('h. Greystone Growler; and Dr. C. L. Parnell are some of the many gentlemen in Canada who have manifested great interest in the breed.

The years of 1911 and 1912 are record ones in the breed; in the former more Airedale Terriers being registered than any other breed but two, and the New York Show bringing out 105 dogs with 204 entries.

Great difference of opinion exists among breeders here as to whether the American-bred of to-day is the equal of, or better than, those of five or more years ago. Be that as it may, the opinion exists that owing to the vast number of carefully bred strains and 
the great numbers of dogs in England, more really high type 'Terriers are produced there to-day than we can hoast of. And again. that their dogs are the result of careful mating, both as to blood lines and as to their general fitness, surely makes for a better average. It would seem that the English custom of putting puppies "out to walk" until they reach the age of six months is better for the pups (if the walks are good), and permits the picking of the hest of each litter, both as to dogs and bitches, and is particularly helpful in the latter ase. for in this way their best are shown and used for brood bitches.

Lnquestionably it would tend to make for the good of the dog if much of the prejudice existing in the I'nited States against the bitch were allayed. The average individual has an unreasonable oljection to keeping a bitch, thinking they are a world of trouble; while. on the contrary, a bitch is much better in many respects, and as a rule more raluable, than a dog from a monetary standpoint. She is always the best house-dog, deaner, sweeter-tempered, will not be so liable to hunt and rum away as will the dog, and makes a better watch-dog for this very reason. A very little care twice a year for a period of three weeks is all that is necessary, and from the standpoint of value, unless the dog is an exceptional specimen, he does not eren earn his feed. while the arerage bitch with one litter a year is quite profitable.

If breeders will do all they can to overeome this prejudice, put their hitches "out to walk" on breeding agreements, as the writer is always willing to do, instead of selling, it should show improvement in bitches.

We are proverbially a hasty nation, and in the breeding of dogs as in all else, with our usual haste and the desire to accomplish the hest results in the shortest period of time, will not display the patience, take the time, and give the study to the subject of breeding that the English undoubtedly do. It is a question whether quite a number of our winners are not either "sports" or correct chance matings, rather than the result of a careful bit of breeding through several generations of skilful selection. If you will look over the average litter, you will hest realize the truth of this statement, for instead of six or eight Terriers, all of a general type and size, out of which it is hard to select the best, one will see an amazing variety of all sorts, one or two standing 'way out (even they with distinct differences of type), and their pedigrees will he 


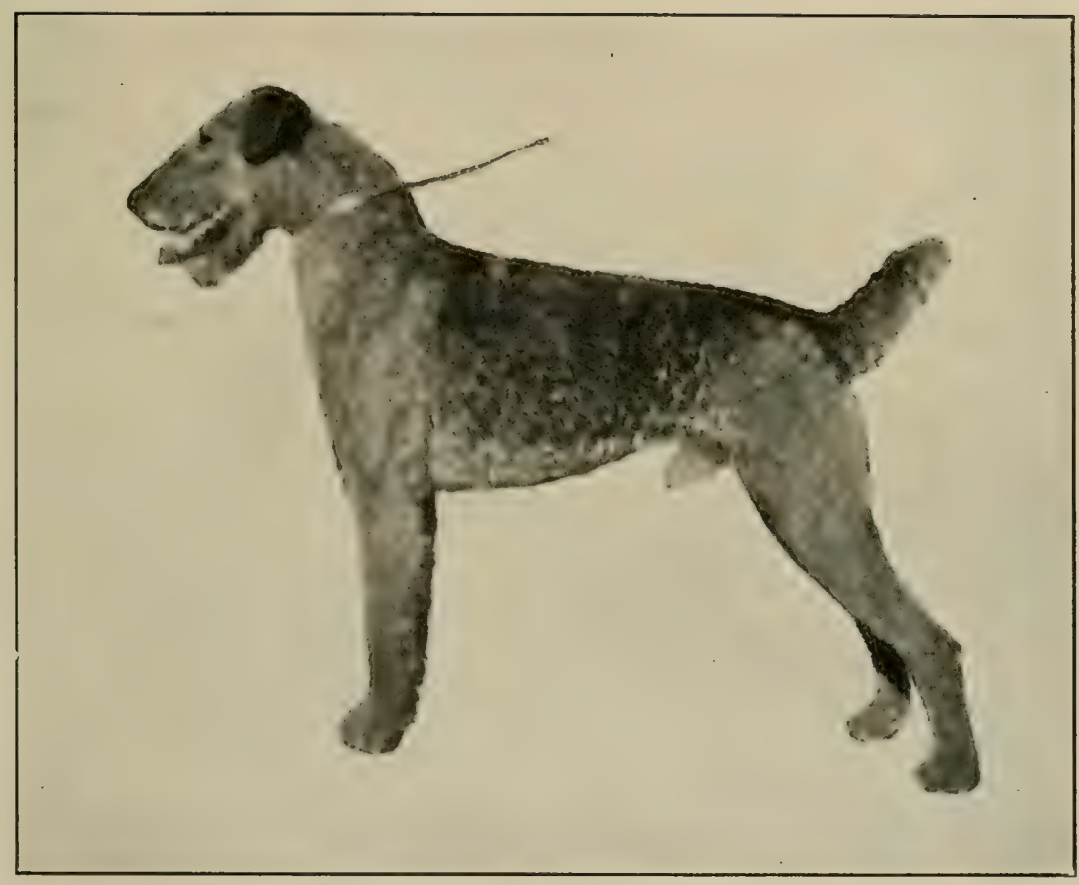

CH. THAYERDALE TENNY

A. K. C. S. B. 134,096

Whelped Oct. 25, 1909. By Ch. Motor Dace ex Ingafield Wild Rose Owned by Mr. Alexander Russell, San Francisco, Cal. 

pointed to by their breeder as containing a glorious potpourri of Champions.

On the other hand, it must not be lost sight of that there are a number of home-breds equal to the best imported specimens, and a number of breeders who for a long period have carefully bred their strains along certain lines. They are the ones that are getting nearly the same results as our English cousins, and are generally to be found in the winners' list at the shows. A novice breeder will do well to acquaint himself with these strains and start his breeding operations with bitches from them, and so at least make a right start in the game; and also do not forget that the kennel with the largest number of imported dogs does not necessarily contain all of the best stock, as the little fellow who has perhaps not the price, and in consequence has to work hard to breed his winners, may have a number of Terriers just as good, and just as carefully bred, that, had they the reputation of being imported, might do much better in the show ring.

As to stud dogs, there can be little question that the scales are heavily weighted in favor of the imported dogs; but, sad to relate, all that glitters is not gold, and quite a number of "flat catehers" have been brought over from the other side, and, what is even worse, have won largely because of that fact rather than on their individual merits. A glance at the list of Champions of Record of both countries shows what a drain we have made on the Mother Country in the past two years, and the writer's statement, which he made in an article last year, that this should tend to make a noticeable improvement in the home-bred in the coming year, is being borne out by the increasing number of promising youngsters that have been shown, commeneing with the New York Show of 1912.

The average enthusiast is still paying little attention to the natural law of selection, and takes too much notice of the latest winner, as one instance that has recently come to notice will illustrate. The ease in point is of two stud dogs, both imported in the past year. One has been shown a great deal, the other very seldom since his arrival. Both are good Terriers, though of different types. The second, an older dog with a long bench record and an exceptional record for getting winners, has had less than twenty visiting bitches. The first is a young dog and has had over a hundred bitches sent to him. Now, aside from the relative merits of these 


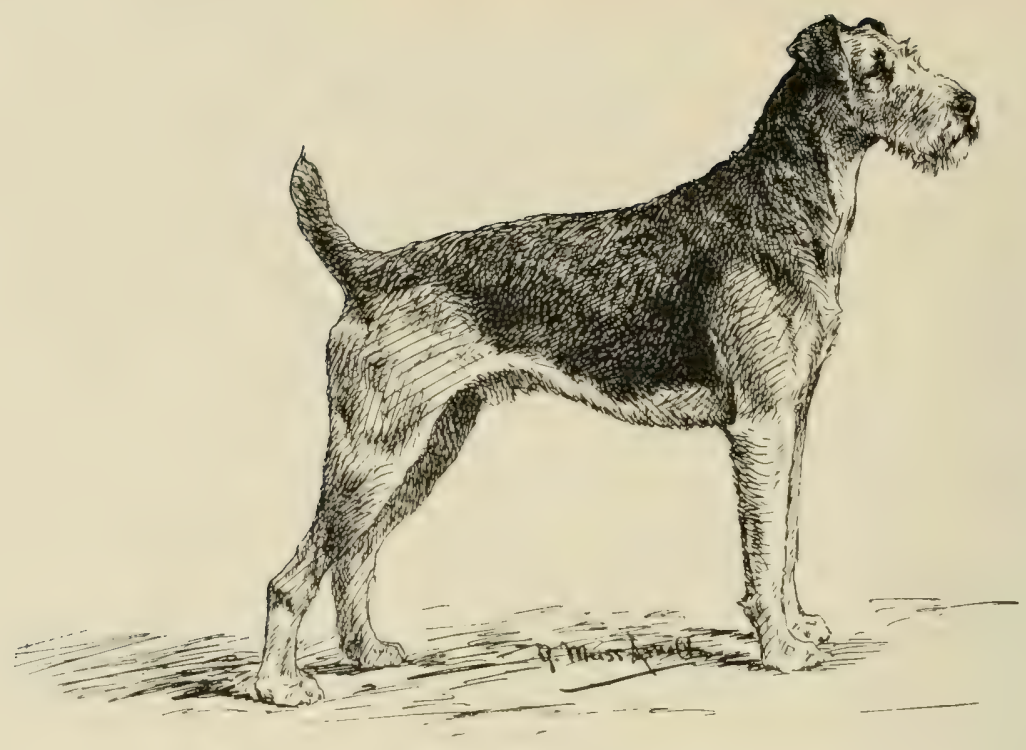

CH. KISMET FLASHLIGHT

A. K. C. S. B. 92,661

By F'loriform ex Kismet Kumyss

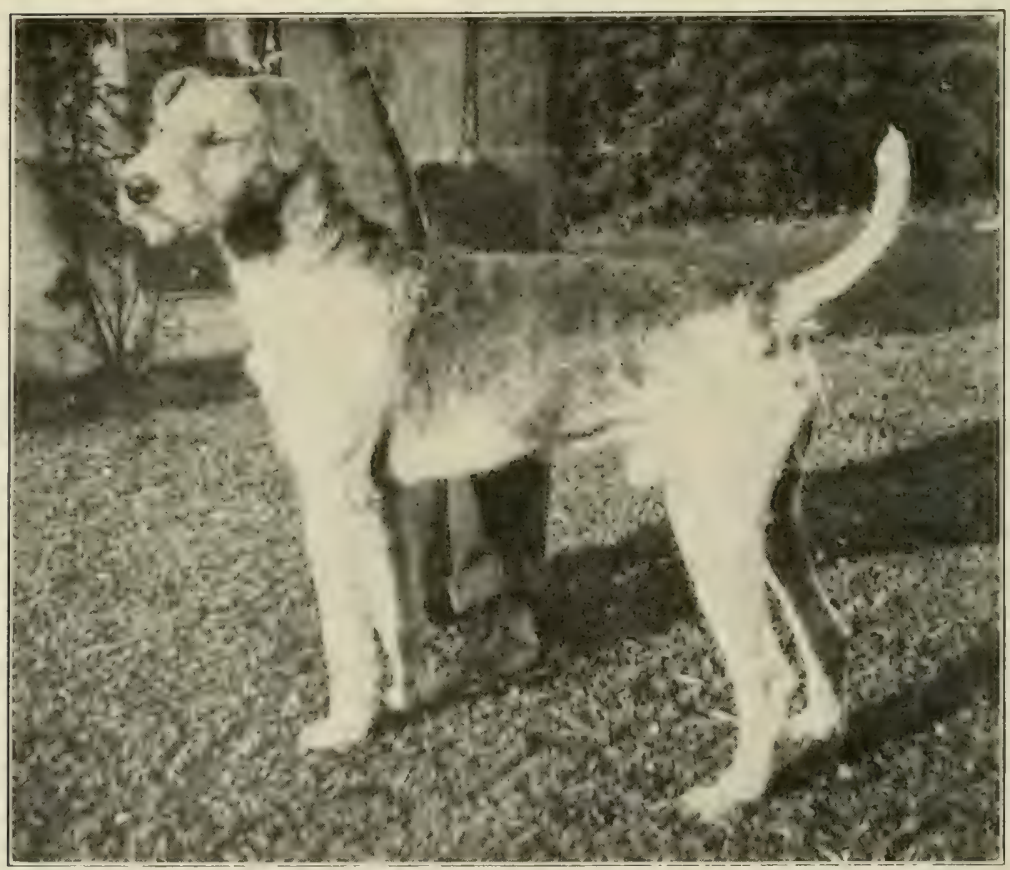

ARNECLIFF JACOBITE

A. K. C. S. B. 123,497

Whelped June 9, 1908. By Ch. Briars Masterpiece ex Kismet Fire Fly 
two dogs, it is clearly on the face of it wrong, and it can be seen that this wrong will be perpetuated; for even an inferior dog, with so great a preponderance of opportunity, might easily show a better but misleading record for getting winners than a superior dog with little or no opportunity.

The writer claims this is one of the stumbling-blocks to success in the way of the American breeder, and one of the real reasons that we do not do better generally; or perhaps it were better put to say that it is extremely creditahle that we have done so remarkahly well under adverse conditions.

Who knows but what we would now lead instead of following if the American-bred stud dog had at least been given an equal opportunity with his imported brother? For no small number of them have had some splendid get, even handicapped as they have been by lack of opportunity; and comparison with the lists of Champions of Record of both countries shows that more Champions were sired by dogs not Champions themselves than were sired by dogs who were Champions of Record.

Of all the famous stud dogs, Clommel Monarch holds the record, having gotten nine English and American Champions. Then come Naster Briar, with seren; Rockley Oorang, with six; York Masterpiece and Crompton Oorang, with five; Rock Salt and Bolton Woods Briar, with four; Endeliffe Crack, Red Raven, the Gamecock and the New King, with three each to their credit; Crompton Performer, Freeman Terror, Lance Corporal Smythe, Master Royal, Midland Royal and Matlock Bob, with two each; and Briar Masterpiece, Chorister, Notor Dace, Soudan Swiveller, Prince of York, Riding Master and York the Hayseed, each getting one. Of the Champion bitches, Babs had two pups that attained their Championship; and Long Hill Peggy, Larchmere Bittersweet, Red Sunlight and York Victoria each had one pup that became a Champion.

Of the dogs who sired Champions and yet never attained that honor themselves, Elruge IIonarch heads the list with a get of five Champions. Crompton Marvel and Odsal Crack got four each; Floriform, Wyndhill Vandal and Tintern Desire, three each; Briar Test, Briarwood, Clonmel Chilperic, Woodman Rival, Primrose King, Crosswicks Dandy, Rockferry Test, Rockferry Bobs and Wombwell Rattler, two each; and Blackburn Brick, Brownhill Pluto, Clip, Clipper Clonmel Barabbas, Clonmel Marvel, Clonmel Rough and Ready, Colne Tyke, Cornet, Danny Graig Prince, Defiance, 
Derryfield Tony, Dreadnanght, Dumbarton Conqueror, Holy Friar, Ingafield Briar, Jerry, Jerry II, Jack Oorang, Lakeview Clipstone Pride, Jarehmere Trapper, Marksman, Midland Agrippa, Midland Rollo, Nipper, Odsal BBob, Percy Darier II, Primrose Rebound, Red Stone Briar, Regulator, Rockferry Conqueror, Royston King, Springbank Performer, Strathearn Barkerend Monitor, Studholme Spark, Tone Grip, Watlands Duke and Wellington King have one each to their credit.

Another point that hid fair to split two sections of this country wide apart was that of Weight. In consequence of a letter sent to one of the liennel paper's by Mr. Theodore Offerman, headed "Shall the Standard be ('hanged?', arguments as to whether the weight as set down in the Standard was to be literally adhered to, whether it should be left to the discretion of the judges, or whether the Standard Weight should be increased, were bandied hack and forth until the suhject herame rather tiresome and was no nearer settlement at the end than the beginning.

For the benefit of English readers, I will explain that the Eastern bresders-which term embrares the sertions in the neighborhood of New York. Philadelphia, and Boston-have generally hred to the Standard Weight, of course always having a preference for a good large one with quality, rather than a good little one. The Western farction, partimlarly the far Western breeders, who discovered the value of this dog in hunting bear, wanted a Terrier (the word is ineongruous in this instance of from 50 to 70 pounds, who in consecquence of his greater weight was more successful for their purposes than one nearer the Standard of 40 to 45 pounds; and it was manifestly impossible to hreed so large a dog, all at once, with the needed cuality, and the big, coarse 'Terrier was sure to go down before the smaller or Standard quality ones in the competition of the show ring. Thus a rertain amount of dissatisfaction was apparent.

Not that the Westerners do not appreciate quality, but finding out the natural aptitude and wonderful head work and discretion displayed by this great Terrier in a new field of sport (and one for which he was surely not bred), they at first hand, and without due thought, allowed their desire to rum away with their judgment.

Instead of repeating what the owners of the English Wire-haired Black and Tan Terrier did when he was found too small for the work he was being used for, and evolving a new breed by crosses 


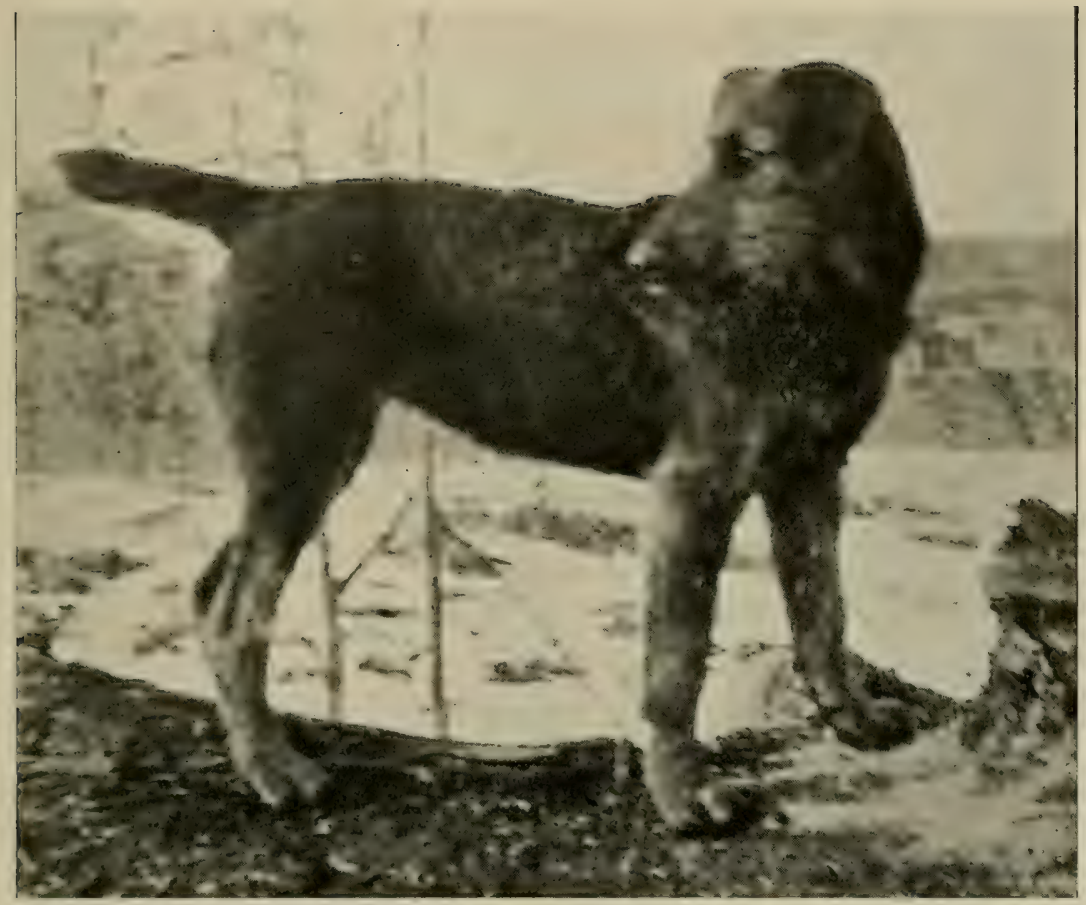

OTIS BRUNETTE

At 6 Months

A. K. C. S. B. 165,967

Whelped June 30, 1912. By Otis Onward ex Otis Briar Peggy

Owned by Otis Kennels 

with another breed for size, they figured that by breeding size to size the same would be quickly accomplished, and they got results as to size, but it was at the sacrifice of quality and Terrier conformation.

Notwithstanding the interest in this matter, there was a noticeable inclination to dodge the issue until a resolution was introduced by the late $\mathrm{Mr}$. George Batson at the yearly meeting of the Airedale Club of America, which was passed, calling on the President of the Club, Mr. Johnson, to appoint a Committee to report in two months as to the sense of the breeders at large on a change in the Standard Weight.

This Committee, consisting of Mr. William Mulford, Mr. Philip French and Mr. John McGough, made a report based on the opinion of forty-two members as against a change; Mr. McGough refusing to sign the report sent him on its completion, claiming that "the Committee should have gone more thoroughly into the subject." This subject, thus whitewashed, is left in its original state to crop out again and cause trouble at some future time.

As to judges, we are evidently in much the same strait that the English are, judging by the controversy in the English kennel papers of late. Owing to a prejudice against the professional, and possibly a lack of timber or inclination in the amateur ranks, considerable criticism has resulted.

The professional judge, if conscientious and honest, should be as good as the amateur, if for nothing else than because it is his profession. He should make more of a study of the dog and see more of the shows than does the amateur (who is generally showing his own dogs); and as serious mistakes affect his living, his judgments shonld be more careful. As in any body, there are always some not above reproach, it would perhaps be better if the A. K. C. licensed them; and with the chance of being "put on the carpet" and disqualified, there would be very little left to criticise.

The amateur sometimes looks on his errors in the light of a joke, does not feel called upon to explain his placings, and feels a contempt for his brother professional, yet he is just as liable to be swayed by either friendship or the fact that he has sold some of the dogs he is judging. He is the stand-by of the Bench Show Committee of the many ribhon shows, from the standpoint of economy; and if he can get a good entry, that is all that they are concerned about. Also, too many are what in racing would be called "dope 


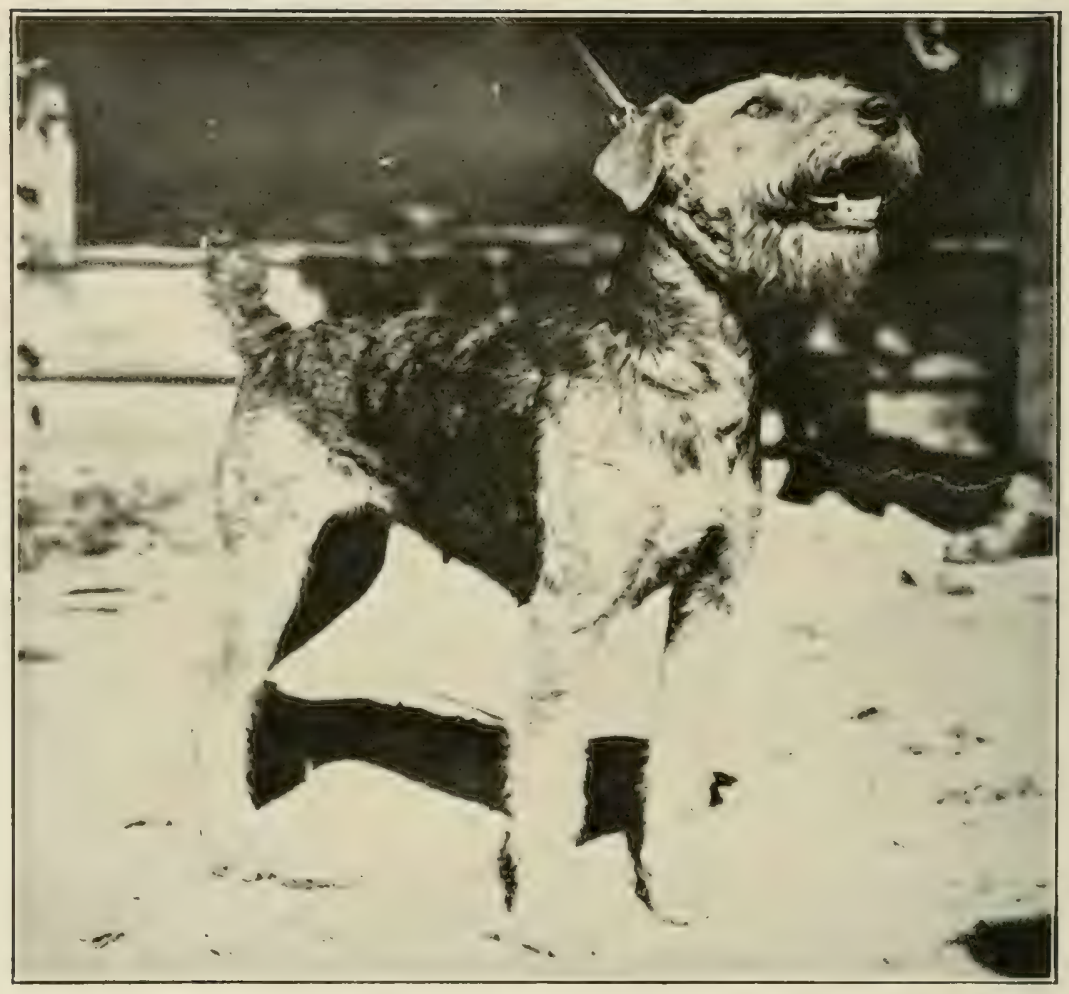

ASHBOURNE FRTLLS

A. K. C. S. B. 137,655

Whelped May 18, 1909. By Ch. Red Raven ex Culbertson Lichen 
fiends" - in other words, have at their fingers' ends the past performances of the various dogs; and this is the reason that too often, if a dog wins on his first appearance, he will continue to do so, while if, on the other hand, he loses, it will militate against him unless he quickly gets shown under several strong judges in succession, to get him placed right in their dope-books.

There are, of course, an equal number of amateur judges as capable and able as their professional brethren, but either from lack of inclination or because they wish to show their own dogs, they too seldom officiate, and the incapable one is always too ready and willing to don the ermine to the detriment of the breed and the game.

In conclusion, I can confidently predict that despite the judging at the many ribhon shows - which shows are the bane of, and will kill, the show game-and all other obstacles, this Terrier is so good that he will survive all fads and setbacks, and year by year will increase in popularity, and always be found in the forefront, both from a monetary and a sentimental point of view.

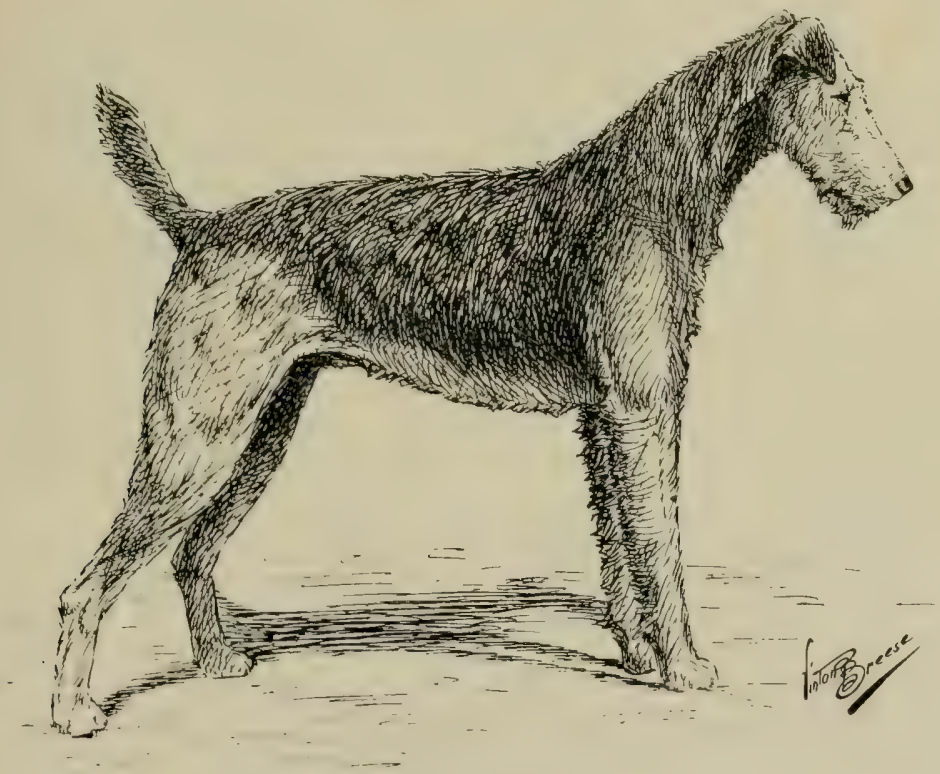

PRETTY FLORRIE

A. K. C. s. B. $19958:$

Whelped June 13, 1903. By Studholme Spark ex Northbrook Florrie 



\section{AIREDALE TERRIER CLUBS IN ENGLAND}

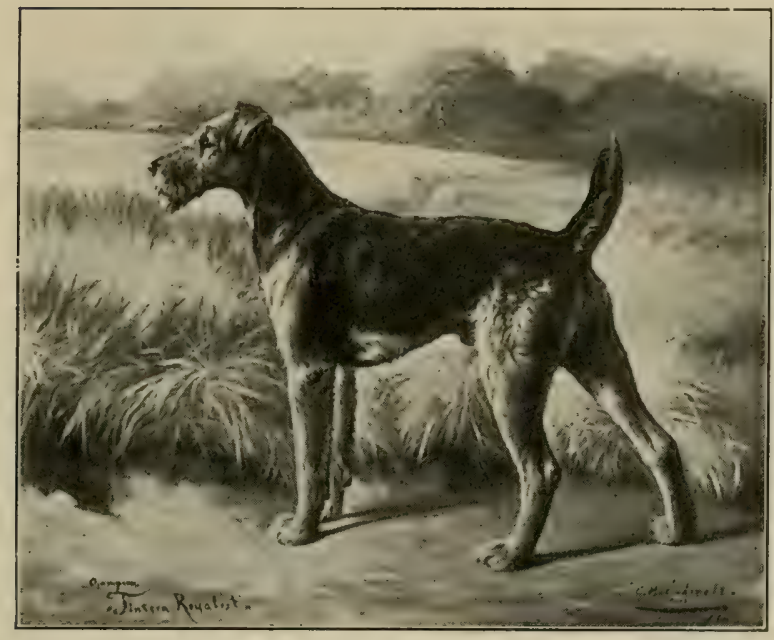

PAINTING OF CH. TINTERN ROYALIST By G. Muss-Arnolt

The Airedale Terrier Club

Midland Counties Airedale Terrier Club

North of England Airedale Terrier Club

South of England Airedale Terrier Club 



\title{
THE AIREDALE TERRIER CLUB
}

FOUNDED 1892

\section{OFFICERS}

\author{
PRESIDENT \\ E. BLUNT, Esq. \\ VICE-PRESIDENTS \\ C. P. WALKER, Esq. \\ R. RILEY, Esq. \\ W. J. PHILLIPS, Esq. \\ W. H. CHANTLER, Esq. \\ T. WALTON, Esq. \\ T. WILSON, Esq. \\ G. RAPER, Esq. \\ THEO. KERSHAW, Esq. \\ C. H. WILKINSON, Esq.
}

\section{COMMITTEE}

C. P. WALKER, Esq.

W. I. PHILLIPS, Esq.

R. RILEY, Esq.

W. H. CHAN'TLER, Esq.

J. KIRKPATRICK, Esq.

T. WALTON, Esq.

J. G. HORROCKS, Esq.

G. RAPER, Esq.

T. WILSON, Esq.

C. H. WILKINSON, Esq.

THEO. KERSHAW, Esq.

HON. AUDITORS

W. J. PHILLIPS, Esq.

C. II. WILKINSON, Esq.

\author{
HON. TREASURER \\ R. RILEY, Esq. \\ HON. SECRETARY \\ H. CROF'T, Esq., \\ Moor Cottage, Undereliffe, Bradford
}

\section{LIST OF MEMBERS}

Bentley, Dr. H., Bramhall Lane, Stockport

Blunt, Ed., Ivydene, Snarestone

Blair, W., Moorhead, Shipley

Buckley, Holland, Burnham, Bucks 
Croft, H., Moor Cottage, Undercliffe, Bradford Chantler, W. H., Cheadle, Cheshire

Dean \& Parker, Messrs., 18 Hrstings Place, Bradford

Elder, G. H., Castle Green, Taunton, Somerset

Grimshaw, O., 10 Frank Street, Bury

Goodbody, J. B., Clara, King's County, Ireland

Greenhalgh, P. W., Newhey, Rochdale

Hannah, Hy., 54 Lansdown Road, Dublin

Haigh, S., Rusheroft, Baildon

Hirst, W., Crackenedge, Dewsbury

Horrocks, J. G., Victoria Hotel, Bury

Huddleston, G., The School House, Letchworth

Jeeves, Dr. F., Ashfield, Moffat

Jowett, F. M., Moor House, Shipley

King, H. W., 77 Port Arthur Road, Nottingham

Kershaw, Theo., Legrams Lane, Bradford

Kilpatrick, J., 37 Church Lane, Belfast

Massey, Jas., 12 Wolseley Road, S.S., Blackpool

Mills \& Buckley, Messrs., Burnham, Bucks

Moore, J. B., 6 Argyle View, Leeds

Phillips, W. J., Tintern Road, Handsworth, Birmingham

Raper, Geo., Richmond Grange, Gomersal

Riley, Robert, Dene House, Luddenden

Walton \& Jackson, Messis., Tufton Street, Silsien

Walker, C. P., Wolstanton, Staffordshire

Walker, J. J., Richmond House, Dullatur, N.B.

Wilson, T., Springbank, Musselburgh, N.B.

Wilkinson, C. H., Charnwood Street, Derby 


\title{
MTDLAND COUNTIES AIREDALE TERRIER CLUB
}

OFFICERS

PRESIDENT

DR. H. S. CHAVASSE

PAST PRESIDENTS

1907-08-E. BLUNT, Esq.

1908-09-W. J. PHILLIPS, Esq.

1909-10 - W. J. PHILLIPS, Esq.

1910-11-E. GRICE, Esq.

1911-12-W. WATKINS, Esq.

VICE-PRESIDENTS

G. ASHMAN, Esq.

E. BLUNT, Esq.

H. BUCKLEY, Esq.

W. H. BUXTON, Esq.

E. GRICE, Esq.

J. H. LEMING, Esq.

WALLACE MARRS, Esq.
H. E. PACKWOOD, Essq.

W. J. PHILLIPS, Esq.

B. W. SMITH, Esq.

C. P. WATKER, Esq.

J. WHITTINGTON, Esq.

C. H. WILKINSON, Esq.

B. WOOD, Esq.

COMMITTEE
S. H. CAPE, Esq.
C. COPUS, Esq.
W. FOSTER, Esq.
J. GRAYER, Esq.
E. GRICE, Esq.

\begin{abstract}
H. JONES, Esq.
P. W. MORTON, Esq.

W. J. PHILLIPS, Esq.

A. A. SMITH, Esq.

W. WATKINS, Esq.
\end{abstract}

\section{CHAIRMAN}

W. J. PHILLIPS, Esq.

HON. AUDITORS

W. J. PHILLIPS, Esq., and B. WOOD, Esq.

HON. VETERINARY SURGEON

F. E. HEATH, Esq., M.R.C.V.S.

HON. TREASURER AND SECRETARY

I. SMITH, Esq.

64 Antrobus Road, Handsworth 


\section{NORTH OF ENGLAND AIREDALE TERRIER CLUB}

HEADQUARTERS: THE CROSBY HOTEL, MANCHESTER

\section{OFFICERS}

PRESIDENT

J. G. IIORROCKS, Esq., Bury

VICE-PRESIDENTS

HOLLAND BUCKLEY, Esq., Burnham

DR. BEN'LEY, Stockport

IV. J. PHILLIPS, Esq., Birmingham

C. P. WALKER, Esq., Wolstanton

H. ETCHELLS, SR., Esq., Harpurhey

P. W. GREENHALGH, Esq., Rochdale

COMMITTEE

MESSRS. CHARLESWORTH, BOTTOMIEY, BERRY, SCOTT, NEEDHAM, WIITEIEAD, WALLWORK, WOODHFAD, SEED and SQUIRE

HON. AUDITORS

S. CHARLESTORTH, Esq. II. ETCHELLS, JR., Esq.

HON. TREASUREL

Mr. W. H. CHANTLER

Airedale Kennels, Cheadle, Cheshire

HON. SECRETARY

Mr. J. SEWELL-HARDY

97 Jackson Street, Stretford 


\section{SOUTH OF ENGLAND AIREDALE TERRIER CLUB}

\section{OFFICERS}

PRESIDENT

E. ROYSTON MILLS, Esq.

VICE-PRESIDENTS

W. S. GLYNN, Esq.

G. H. ELDER, Esq.
Mr. GEO. HOWLETT, JR.

E. BANES-CONDY, Esq.

E. R. L. HOSKINS, Esq.

HON. SEC. AND TREASURER

H. BUCKLEY, Esq.

COMMITTEE

CAREY BARNARD, Esq.

E. R. L. HOSKINS, Esq.

Mr. GEO. HOWLETT, JR.
J. R. WARTON, Esq.

G. H. ELDER, Esq. ARTHUR LEVER, Esq. 



\section{AIREDALE TERRIER CLUBS IN AMERICA}

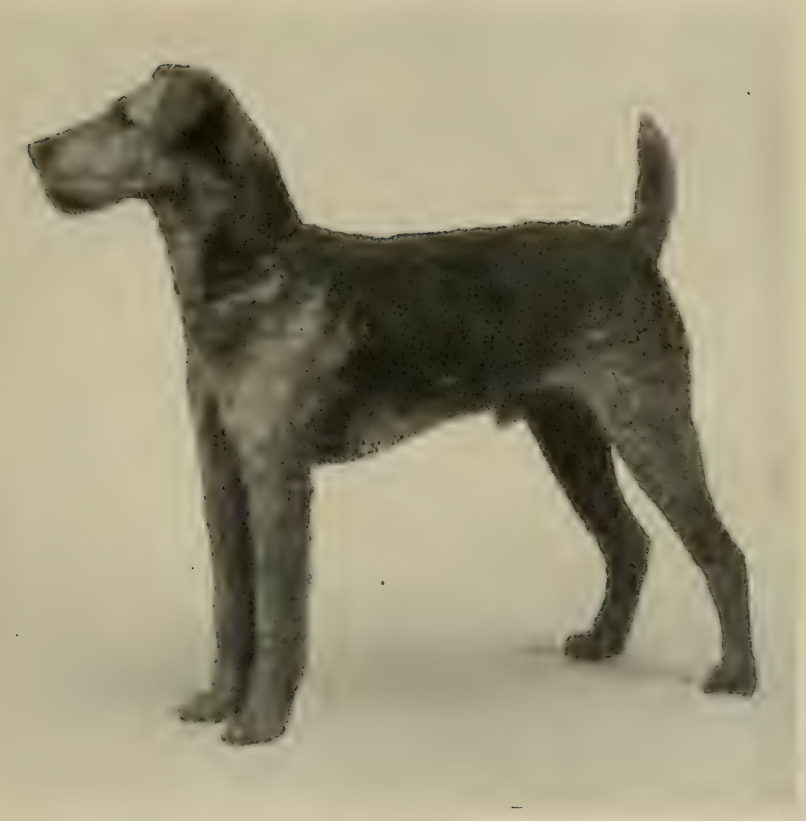

CH. PRINCE OF YORK

Airedale Terrier Club of America Airedale Terrier Club of New England Atredale Terrier Club of New York Airedale Terrier Club of Canada Atredale Terrier Club of Long Island

California Airedale Terrier Club The Western Airedale Terrier Club The Northwestern Airedale Terrier Club

EDITORIAL NOTE. - The publisher has made constant efforts to secure full information from the secretaries of these clubs, and if any information is missing, it is solely due to their failure to supply him with same. 



\title{
THE AIREDALE TERRIER CLUB OF AMERICA
}

FOUNDED 1900

\section{OFFICERS}

\author{
PRESIDENT \\ RUSSELL H. JOHNSON, JR. \\ FIRST VICE-PRESIDENT \\ ROBT. JORDAN \\ SECOND VICE-PRESIDENT \\ FRANCIS G. PORTER \\ THIRD VICE-PRESIDENT \\ WM. P. WOLCOTT \\ TREASURER \\ HOWARD EHRICH \\ SECRETARY \\ THEODORE OFFERMAN, \\ 503 Fulton St., Brooklyn, N. Y. \\ DELEGATE TO A. K. C. \\ WM. L. BARCLAY
}

\section{CONSTITUTION}

\section{ARTICLE I}

The name of the Club shall be "THE AIREDALE TERRIER CLUB OF AMERICA.",

\section{ARTICLE II}

This Club is established with a view to promote the breeding of pure Airedale terriers; to define precisely and publish a definition of the true type; and to 
urge the adoption of such type on breeders, judges, dog show committees, etc., as the only recognized and unvarying standard by which Airedale Terriers ought to be judged, which may in the future be uniformly accepted as a sole standard of excellence in breeding and awarding prizes of merit; and by giving prizes, supporting shows, and taking other steps to do all in its power to protect and advance the interests of the breed.

\section{ARTICLE III}

The government and management of the Club shall be vested in an Executive Committee, comprised of the officers of the Club, which shall be a President, a First Vice-President; a Second Vice-President, a Third Vice-President, a Treasurer and a Secretary. They shall be elected annually at a general meeting of the Club.

\section{ARTICLE IV}

The Executive Committee shall annually select from its members a President, three Vice-Presidents, a Secretary and a Treasurer.

\section{ARTICLE V}

Such officers or any of them, and the Committee or members thereof, may, at any time, for violation of duty, be removed by the Executive Committee, and the vacancies filled.

\section{ARTICLE VI}

The Executive Committee shall cause to be prepared aunually a detailed statement of the financial condition of the Club, showing its receipts and expenditures for the current year, the number of members, other matters of interest to the Club, and a copy forwarded to each member. The fiscal year shall terminate on the 31st of December of each year.

\section{ARTICLE VII}

The interpretation of these rules shall be given by the Executive Committee.

\section{ARTICLE VIII}

The number of members of this Club shall be unlimited.

\section{AR'TICLE IX}

The President, or in his absence, the Vice-President, shall preside at all meetings of the Club, or of the Executive Committee, and shall have power to call all special meetings.

\section{ARTICLE X}

The Secretary shall keep the complete record of all meetings of the Club, or Executive Committee, and of all matters of which a record shall be ordered by the Club. He shall have charge of the correspondence of the Club. On the election of a member, he shall send him a written notice of his election, and 
furnish him with a printed copy of the rules and standard of the Club, and request him to pay his entrance fee and annual dues. He shall notify officers and members of their election, or appointment, and shall issue notices to members of all meetings. ITe shall keep a roll of the Club, with their addresses.

\section{ARTICLE XI}

The Treasurer shall collect and receive all moneys due or belonging to the Club, and receipt therefor. He shall deposit the same in a bank in the name of the Club, and notify the Executive Committee of the same. Ilis books shall be open at all times to the inspection of the Executive Committee, and he shall report to them at every meeting the condition of the finances of the Club when requested; and at the annual meeting of the Club he shall render an account of all moneys received and expended during the year previous, which account must be audited by the President of the Club.

\section{ARTICLE XII}

Every candidate for membership shall be proposed and seconded by two members of the Club.

\section{ARTICLE XIII}

The name, profession and residence of the candidate shall be sent by the proposers to the Secretary.

\section{ARTICLE XIV}

The Executive Committee shall have full power to elect members. Candidates whose names have been laid over for two successive meetings cannot be presented to the Executive Committee again.

\section{ARTICLE XV}

Erery person shall within thirty days after notification by the Seeretary, pay to the Treasurer his entrance fees and annual dues, and shall then, and not before, be a member of the Club. In ease of failure to do this, his election shall be void, at the discretion of the Executive Committee.

\section{ARTICLE XVI}

The interest of any member in the property of the Club ceases with the termination of his membership.

\section{ARTICLE XVII}

The Executive Committee shall have the power by a two-thirds vote of the entire Committee, to forfeit the membership of any member of the Club for conduct on his part likely, in the opinion of the Committee, to endanger the welfare or character of the Club.

\section{ARTICLE XVIII}

Notice shall be mailed to each member when his annual dues are payable, and should such dues remain unpaid sixty days after such notice has been given, 
he ceases to be a member of the Club, except in eases of absence from the country, which shall be left to the discretion of the Executive Committee.

\section{ARTICLE XIX}

The Club may be dissolved at any time, with the written consent of not less than two-thirds of the members for the time being. After payment of all the debts and liabilities of the Club, its properties and its assets shall be divided equally among the members.

\section{ARTICLE XX}

The Club shall hold annual meetings during the week of the Westminster Kennel Club Show and five shall be a quorum.

\section{ARTICLE XXI}

A special meeting of the Club shall be ealled by the President, upon a written request of three members of the Club.

\section{ARTICLE XXII}

This Constitution can be amended only by a two-thirds vote of the members present at a regular or special meeting.

\section{ARTICLE XXIII}

At the meetings of the Club, the order of business, so far as the character and nature of the meeting may admit, shall be as follows:

1. Calling of Roll and Reading of Minutes.

2. Report of Committees.

3. Election.

4. General Business.

5. Adjournment.

\section{ARTICLE XXIV}

All special Committees shall be appointed by the Chair, unless otherwise ordered in the motion.

\section{ARTICLE XXV}

Every member shall pay an entrance fee of five dollars, and the sum of five dollars in annual dues, payable on the first day of January of each year. Members joining the Club after the first day in September of any year, shall pay half the annual dues for the balance of the year.

\section{ARTICLE XXVI}

All resignations must be made in writing and addressed to the Secretary of the Club; no member ean resign while he is in debt to the Club. 


\section{ARTICLE XXVII}

Three members of the Executive Committee shall constitute a quorum for the transaction of business.

\section{ARTICLE XXVIII}

In case a dog is owned by a firm or kennel, each member of such firm or kennel must become a member of the Airedale Terrier Club of America before the $\mathrm{dog}$ is eligible to compete for Airedale Terrier Club specials.

THE STANDARD

The Standard adopted by this Club is identical with the English Standard.

\section{SHOWS HELD}

This Club held its first show December 9, 1911, with Mr. J. R. Thorndike judging, and had an entry of 67 dogs.

The second show was held November 9, 1912, with Mr. Wm. L. Barclay judging, and had an entry of 56 dogs.

\section{SPECIALS}

The Airedale Bowl, for the best Airedale Terrier owned by a member. The Bowl to be offered five times a year for five years, at the end of which period to be awarded to the member winning it the greatest number of times. A Club medal to be awarded at each win.

\section{LIST OF MEMBERS}

Albright, Andrew, Jr., 56 Ferry Street, Newark, N. J.

Ames, Fisher, Boston, Mass.

Bain, Jas. W., 137 Bedford Road, Toronto, Ont., Canada.

Baker, W. Edgar, Jr., 105 W. 40th Street, New York City.

Barclay, W. L., Chestnut Hill, Philadelphia, Pa.

Bastow, Henry, 300 Albany Avenue, Brooklyn, N. Y.

Bellin, T. S., care of W. M. Whitney Co., Albany, N. Y.

Biddle, Lynford, Chestnut Hill, Philadelphia, Pa.

Bolster, R. J., 40 Main Street, Battle Creek, Mich.

Bryant, J. N. R., 213 10th Street, Long Island City, N. Y.

Carter, Wm. E., Bryn Mawr, Pa.

Cadwalader, Thos., 133 So. 12th Street, Philadelphia, Pa.

Condee, R. W., 4640 Lake Avenue, Chicago, Ill.

Crawford, Mrs. A. E., Evanston, Ill.

Creed, W. H., Shattuck Avenue, Berkeley, Cal.

Denby, S. C., Wool Ex., New York City.

Echeverria, Dr. M. J., 248 W. 76th Street, New York City. 
Ehrich, Manfred W., 2 Rector Street, New York City. Ehrich, Howard, 43 Exchange Place, New York City.

Eyth, Frank, Butler, Pa.

French, Philip, 200 Commonwealth Arenue, Boston, Mass.

Gates, Mrs. Merrill E., Jr., Scarsdale, N. Y.

Golle, Clement H., Consumers Ice Co., El Paso, Tex.

Harding, Ed., 43 Exchange Place, New York City.

Harrison, M. W., Jr., Racquet Club, 215 So. 16th Street, Philadelphia, Pa.

$>$ Havens, Fred C., Laurel Arenue, Point Pleasant, N. J.

Henry, Howard H., Fort Washington, Pa.

Herkness, Gilbert, Wyncote, Pa.

Hill, Dr. F. W., 619 Oakwood Boulevard, Chicago, Ill.

Jennings, M., 9 Highview Avenue, Jamaica, L. I., N. Y.

Johnson, Russell H., Jr., Chestnut Hill, Philadelphia, Pa.

Jordan, Robt., Box 55, Boston, Mass.

Kennedy, Miss Maud, 40 E. 52d Street, New York City.

Laurin, Jos. A., Montreal, Que., Canada.

Lee, Robt. L., 40 W. 45 th Street, New York City.

Maclay, Alfred B., 358 5th Avenue, New York City.

McCrea, Andrew, Chestnut Hill, Philadelphia, Pa.

MeGough, J., 56 Prospect Street, Flatbush, Brooklyn.

Meyer, Eugene, Jr., 7 Wall Street, New York City.

Monnot, C. L., Jeanerette, La.

Mortimer, Jas. (Life Member), Hempstead, L. I., N. Y.

Marquardt, E. G., Osborn and Mark Lane, Burlington, Ia.

Mulford, W. H., Wyncote, Pa.

Mulford, Mrs. W. H., Wyncote, Pa.

Murray, John, Eatontown, N. J.

Munger, Ed. A., 107 Dearborn Street, Chieago, Ill.

Newbold, Clement B., 112 Drexel Building, Philadelphia, Pa.

Ober, Harold, eare of Paul R. Reynolds, 70 th Arenue, New York City.

Offerman, Theo., 503 Fulton Street, Brooklyn, N. Y.

Page, Mrs. J. A., Allen Lane, Germantown, Pa.

Palmer, Dr. W. W., Saugerties, N. Y.

Parnall, Dr. C. G., Jackson, Mich.

Patterson, W. F., 100 William Street, New York City.

Perrin, C. H., 2735 Sheridan Road, Evanston, Ill.

Post, Ed. M., Am. Equi. Co., 111 Broadway, New York City.

Pöter, Francis G., 159 La Salle Street, Chicago, Ill.

Price, J. Sergeant, Jr., Chestnut Hill, Philadelphia, Pa.

Proctor, A. B., Orangeburg, N. Y.

Reeve, W. F., 31 Market Street, Camden, N. J.

Riker, D. S., 46 Cedar Street, New York City.

Riker, Herbert L., 303 Madison Avenue, New York City.

Rockwood, Chas. P., Indianapolis, Ind., P. O. Box 472.

Sims, Jos. P., Chestnut Hill, Philadelphiä, Pa.

Snyder, Maurice R., Chestnut Hill, Philadelphia, Pa.

Spring, Jas. W., Tremont Building, Boston, Mass. 
Sterrett, J. D., Erie, Pa.

Stoehr, Max W., 136 Pennington Avenue, Passaic, N. J.

Taylor, John I., 246 Washington Street, Boston, Mass.

Toney, Dr. L. C., 2914 S. Vermont Avenue, Los Angeles, Cal.

Thorndike, J. R., 121 Marlborough Street, Boston, Mass.

Tucker, Gilbert M., Jr., Albany, N. Y.

Usher, J. F. H., 45 King Street, W., Toronto, Ont., Canada.

Vandergrift, Jos. B., 25 East 26th Street, New York City.

Wakefield, Geo., 36 Oakley Avenue, White Plains, N. Y.

Whittem, W. H., Chestnut Hill, Philadelphia, Pa.

Wolcott, Wm. P., Readville, Mass.

West, Geo. S., Chestnut Hill, Mass. 



\section{ATREDALE TERRIER CLUB OF NEW ENGLAND}

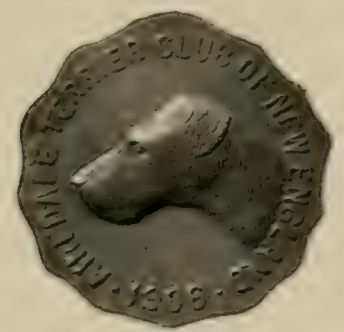

FOUNDED 1906

\section{OFFICERS}

PRESIDENT

GEORGE S. WEST

VICE-PRESIDENT

ROBERT JORDAN

SECRETARY AND THEASURER

JAMES W. SPRING

EXECUTIVE COMMITTEE

GEORGE S. WEST ROBERT JORDAN JAMES W. SPRTNG FISHER AMES, JR.
FRANK H. JACKSON

HAROLD READ

JOHN R. THORNDIKE

WILLTAM P. WOLCOTT

Mr. Arthur Merritt and Mr. Plilip French, of Boston, conceived the jdea of forming the Airedale Terrier Club of New England at the New York Show in Feluruary. 1906. On April 23. 1906, they. with Mr. Fislyer Ames. Jr., and Mr. Talter .J. Burgess, organized the Club, which was incorporated "for the purpose of encouraging the raising of pure Airedale Terriers."

The first meeting was held April 30. 1906, and the following loylaws were adopted: 


\section{BY-LAWS}

\section{ARTICLE I \\ PERSONS ELIGIBLE TO MEMBERSHIP}

Any person interested in the purpose for which the Club is constituted shall be eligible to membership.

\section{ARTICLE II}

\section{OFFICERS AND AGENTS AND THEIR ELECTION}

SECtion 1. The officers and agents by whom the purpose of the Club shall be carried out shall be as follows, to wit:

A President.

A Vice-President.

A Secretary with the powers and duties of Clerk, and who shall also be Treasurer.

An Executive Committee with the powers of directors, to consist of the President and the Secretary ex officio and five other members.

SECTION 2. The aforesaid officers and Executive Committee shall be elected by ballot, and shall hold office until the adjournment of the Aunual Meeting to be held on the first Friday of April, A.D. 1907. At said meeting, and at each annual meeting thereafter, the said officers and Executive Committee shall be elected by ballot, and shall hold office until the adjournment of the Annual Meeting then next ensuing, or until their respective successors are elected.

\section{ARTICLE III}

\section{DUTIES OF OFFICERS}

SECTION 1. The President shall preside at all meetings of the Club and of the Exécutive Committee. He shall, with the Treasurer, sign all deeds, leases and other instruments required to be under the seal of the Club.

He shall be the executive officer of the Club and of the Executive Committee.

SeCtion 2. The Vice-President shall assume the office and duties of the President during his absence or disability.

Section 3. The Secretary and Treasurer shall as Secretary keep an accurate record of all meetings of the Club in suitable books; keep an accurate list of the members, with their addresses; notify all members of all meetings of the Club, whether annual or special, by a notice in writing; he shall be the Secretary of the Executive Committee and keep the records of said Committee; he shall notify each person elected to membership, and each member elected to office, in the Club, of such election.

He shall as Treasurer have the custody of the Corporate Seal and of all the chattels of the Club; he shall collect all dues and all moneys due to the Club from whatever source, and shall disburse the moneys of the Club on the legal order of the Executive Committee; he shall keep an accurate account of all receipts and disbursements of the Club in suitable books; he shall, with the President, sign all deeds, leases and other instruments required to be under the 
seal of the Club; he shall make report at the Annual Meeting of the Club; he shall perform such other duties as the Executive Committee may require.

SECTION 4. The Executive Committee shall have the government and management of the Club; they shall have full power to elect to membership persons eligible under Article I; they may, by a vote of five-sevenths of the entire Committee, expel from membership in the Club any member for conduct likely to endanger the purpose, welfare, or character of the Club; they shall elect one of their number, other than the President, to be chairman of the Executive Committee, who shall, in the absence of the President and to the exclusion of the Vice-President, preside at meetings of the Committee; they shall fill any vacancy in any office or in said Committee until the next annual meeting; five members of the Committee shall constitute a quorum for the transaction of business.

\section{ARTICLE IV}

\section{ELECTION OF MEMBERS}

Candidates for membership shall be proposed by one member in writing, and seconded in writing by another member, and shall sign a written agreement to abide by all existing or future By-Laws and rules.

All proposals for membership shall be referred to the Executive Committee, and the unanimous vote of all the members of the Executive Committee present at any meeting for the election of members shall be necessary to elect a candidate.

The Secretary shall give to each person elected to membership immediate notice of his election and of the date thereof.

\section{ARTICLE V}

FEES AND DUES

The initiation fee shall be five dollars and shall be paid by each person elected to membership within ten days from the date of his election; and if not paid within that time, his election shall be roid unless the Executive Committee shall otherwise order.

The Annual Dues shall be five dollars, payable January 1. But any person elected to membership within three months prior to January 1 shall be exempt from Annual Dues for the ensuing year.

If after the expiration of thirty days from the date of the Annual Meeting the Annual Dues of any member shall remain unpaid, the Secretary and Treasurer shall give such member immediate written notice thereof, and unless such member shall, within seven days from the date of such notice, pay such dues, he shall forfeit his membership and all his rights and privileges unless the Executive Committee shall otherwise order.

\section{ARTICLE VI}

\section{AS TO JOINT OWNERSHIP OF DOG}

In case a dog is owned by a firm or Kennel, each member of such firm or Kennel must become a member of the Airedale Terrier Club of New England before the dog can be eligible to compete for Club specials. 


\section{ARTICLE VII}

MEETINGS

The Amnual Meeting of the Club shall be held on the first Friday in April.

Special meetings may be called by the President or by a rote of the Executive Committee.

Notice in writing of each annual or special meeting shall be sent by the Secretary and Treasurer, seren days at least before the date of such meeting.

\section{ARTICLE VIII}

\section{QUORUM}

Until the election of new members a majority of the members shall constitute a quorum for the transaction of business. After the election of new members, seven members shall constitute a quorum of any meeting holden at the time and place appointed for the meeting and presided over by the regular officers of the club.

\section{ARTICLE IX}

\section{AMLENDMENTS}

These By-Laws may be amended at any annual meeting or at any special meeting by rote of three-fourths of the members present and roting, provided that any proposed amendment shall have been filed in writing with the Secretary and Treasurer at least ten days before any meeting at which action thereon is to be taken, and shall have been by him printed in full and sent to each member upon the notice for the meeting at which the proposed amendment is to be acted upon; and such amendment shall be rejected or adopted without in itself being amended.

These Ty-Laws remained in force until the annual meeting in April, 1912, when they were amended by increasing the number of the Executive Committee trom seven to eight and by adding an article called Article $\mathrm{X}$. which was as follows:

\section{ARTICLE X}

The Secretary shall have full power to offer special prizes in his discretion, which prizes shall consist of not more than two silver and two bronze Club Medals, at all Shows held outside of New England, except at the so-called New York, Wissahickon and Mineola Shows, unless in any instance some member of the Executire Committee shall request the Secretary in writing to eall a meeting of the Executive Committee to consider the giving of specials at any given Show, in which event the Secretary shall call a meeting of the Executive Committee forthwith, and shall act in accordance with its wishes expressed at such meeting. 


\section{STANDARD}

The Standard adopted by this Club is identical with the English Standard.

The first officers of the Club were Arthur Merritt, President; Fisher Ames, Jr., Vice-President; and Philip French, Secretary and Treasurer, who remained in office until the annual meeting in April, 1911, at which time it was voted to create a new office to be called the "Permanent Honorary President," to which MIr. Merritt was elected in recognition of, and to give permanent form to, the Club's appreciation of his many well known and generous services.

At this meeting George S. West was elected President; James W. Spring, Vice-President; and Philip French, Secretary and Treasurer. On Octoher 19, 1911, Mr. French resigned as Secretary and Treasurer, and Mr. Spring resigned as Vice-President. Mr. Robert Jordan was elected Vice-President, and Mr. James W. Spring was elected Secretary and Treasurer.

\section{CLUB SHOWS}

The Club gave the first show ever given in America exclusively for Airedale Terriers on October 2, 1909, at the Larchmere Kennels, Hamilton, Mass. Mr. James Mortimer was the judge, and there were fifty-four (54) dogs actually entered.

The Club has held a Puppy Show, for members only, each year since the Spring of 1908. The first show was held at Mr. Merritt's place in Mattapan on May 9, 1908. There were some twenty (20) puppies shown at this time.

\section{CLUB SPECIALS}

The Club has supported all the New England shows most generously, and has offered its specials at practically all the Eastern shows outside of New England.

Since 1907 the Club has offered annually, at the show of the Ladies' Kennel Association of Massachusetts, a gold medal, open to all. This medal was won

In 1907 by Ch. Wynton Tyke, owned by Mr. Charles F. Leland.

In 1908 by Ch. Larchmere Bittersweet, owned by Mr. Robert Jordan.

In 1909 by Ch. Pilgrim Yellow Jacket, owned by Mr. Fisher Ames, Jr. 
In 1910 by Ch. Larchmere Mistress Magnet, owned by Mr. Robert Jordan.

In 1911 by Larehmere Style, owned by Mr. Robert Jordan.

In 1912 by Ch. Clonmel Command, owned by Mrr. Francis G. Porter.

It will be noticed that until 1912 the gold medal was always won by a member of the Club.

In 1909 the Club offered for annual competition a Breeders' Cup, of sterling silver, costing $\$ 75$. This eup was for "the best registered Airedale under eighteen months, bred by a member of the Club. To be won three times, and a bronze medal for each win to go to the owner of the dog." To be offered at the Boston and Ladies' Kennel Association of Massachusetts Shows until won.

The cup was won

In 1909 by Ch. Pilgrim Yellow Jacket, bred by Mr. Fisher Ames, Jr.

In 1910 twice by Ch. Larchmere Mistress Magnet, bred by Mr. Robert Jordan. In 1911 by Gamecock Dazzler, bred by Mr. George S. West.

In 1911 by Larchmere Style, bred by Mr. Robert Jordan.

This last win gave the eup to Mr. Robert Jordan.

A second Breeders' Trophy, of the same ralue and under the same terms, was offered through the Club in 1912. This trophy was won

In 1912 by Larchmere Proud Prince, bred by Mr. Robert Jordan, and by Larchmere Mistress Briar, bred by Mr. Robert Jordan.

In the Fall of 1911 the Club offered a new trophy, to be called the " 'Airedale Terrier ('lub of New England Shield,' for the best dog or bitch, not neeessarily Ameriean-bred, owned by a member of the Club." This shield is a perpetual challenge shield and remains in the custody of the CIub. It is to he offered each year at the New York and Boston Shows. A Bronze Nedal is given to the owner of the dog to commemorate each win. This shield was won

At New York in 1912 by Ch. Kenmare Sorceress, owned by Mr. William P. Wolcott.

At Boston in 1912 by Ch. Soudan Stamboul, owned by Mr. William P. Wolcott.

The record of the names of the dogs and owners winning these trophies is perpetuated upon a set of quartered oak panels.

The most valuable trophy which the Club owns, and which is always offered open to all, is the "('hampion the New King Bowl," 
a solid silver punch bowl of simple design which is offered "for the best $\operatorname{dog}$ or bitch in the show, not necessarily American-bred." "This bowl is a perpetual challenge bowl and remains in the custody of the Club." A replica of the bowl in plate is given to the owner of the dog wimning it, to commemorate the win. The New King Bowl was given to the Airedale Terrier Club of New England by Mr. Arthur Merritt, its first president, just prior to the Boston Show, in April, 1912, at which it was offered for the first time. Mr. Merritt died shortly after the Show, and one of his last requests was that the bowl should be offered in competition whenever and wherever it was probable that the most representative Airedales in the country would be shown, because in this way he hoped that the name of no dog not worthy of championship honors would appear upon it.

This bowl was won

At Boston in 1912 by Ch. Soudan Stamboul, owned by Mr. William $\mathbf{P}$. Wolcott.

At the Second Annual Show of the Airedale Terrier Club of America, by Ch. Kenmare Sorceress, owned by Mr. William P. Wolcott.

The names of the winning dogs and owners are etched upon it.

The Club holds a dinner each Fall and Spring and gives a complimentary dinner to the Airedale judge each year after the close of the judging at the Boston Show, which dinner is attended by not only all the Airedale men in town, but by all the terrier men and judges.

There are now forty-six (46) members in the Airedale Terrier Club of New England. The names and addresses are as follows:

Ames, Fisher, Jr., care of H. O. Fish, South Duxbury, Mass.

Barbour, Thomas, 195 Fisher Avenue, Brookline, Mass.

Brooks, L. Loring, 218 Exchange Building, Boston, Mass.

Belknap, Francis W., Justamere Farm, South Billerica, Mass.

Burnett, Mrs. John I., Southboro, Mass.

Benton, Charles E., 65 Kilby Street, Boston, Mass.

Bernheimer, Clarence M., Newburyport, Mass.

Coffin, Rockwell A., M.D., 234 Clarendon Street, Boston, Mass.

Cruttenden, Tyler, 82 Wall Street, New Haven, Conn.

Currier, Frank J., Milton Shoe Co., Milton, N. H.

Crocker, William M., 10 Park Vale Avenue, Allston, Mass.

Delapole, H. M., eare of Jordan Marsh Co., Boston, Mass. 
Edmands, F. Albert, 78 Forest Street, Wellesley Hills, Mass. French, Philip, 200 Commonwealth Avenue, Boston, Mass.

Fuller, Mrs. Samuel L., Harrison, N. Y.

Frothingham, Thomas G., 74 Chestnut Street, Boston, Mass.

Fox, H. O., The St. Charles, Atlantic City, N. J.

Fuller, Robert G., Dover, Mass.

Grinnell, Francis B., 447 Washington Street, Brookline, Mass.

Harrington, John C., I Parker Street, Everett, Mass.

Hay, Clarence L., Porcellian Club, Cambridge, Mass.

Jordan, Robert, care of A. O. Clark, Box 55, Boston, Mass.

Jordan, Mrs. Robert, care of A. O. Clark, Box 55, Boston, Mass.

Jordan, Miss Dorothy MI., 46 Beacon Street, Boston, Mass.

Jackson, Frank H., 63 Leamington Road, Aberdeen, Boston.

Leland, Charles F., Southboro, Mass.

Ledyard, William, 5 Ashford Court, Allston, Mass.

Main, Charles E., 91 Bedford Street, Boston, Mass.

Perrin, Arthur, Union Club, Boston, Mass.

Pillsbury, W. H. C., 111 Longwood Avenue, Brookline, Mass.

Perley, Dr. Charles W., 70 Broadway, East Somerville, Mass.

Read, Harold W., 112 Water Street, Boston, Mass.

Rodman, Alfred, Box 2832, Boston, Mass.

Ranlett, Charles A., Billerica, Mass.

Smith, T. Dickson, 53 State Street, Boston, Mass.

Stone, Robert E., 35 Congress Street, Boston, Mass.

Stanton, J. T., R. F. D., Mt. View, Plainville, Conn.

Spring, James W., 340 T'remont Building, Boston, Mass.

Thorndike, J. R., 15 Beacon Street, Boston, Mass.

Towle, Martin A., 92 State Street, Boston, Mass.

Tebbetts, Theodore C., 37 Baltimore Street, Lynn, Mass.

Tuckerman, Bayard, Jr., 108 Water Street, Boston, Mass.

Tignoles, Arthur T., Chestnut Hill Riding School, Chestnut Hill, Mass.

West, George S., Chestuut Hill, Mass.

Wetherbee, W. S., Mirdletown, Comn.

Wolcott, W. P., Readville, Mass. 


\section{THE \\ AIREDALE TERRIER CLUB OF NEW YORK}

OFFICERS

PRESIDENT

THEO. OFFERMAN

VICE-PRESIDENT

SILAS WODELL

SECRETARY AND TREASURER

HOWARD EHRICH

43 Exchange Place, New York

Initiation Fee, $\$ 5.00$

Annual Dues, $\$ 5.00$

STANDARD

The Standard adopted by this Club is identical with the English Standard.

Club medal of silver.

SPECIALS

Club medal of bronze.

The Presinen't's Trophy, for the best dog, to be won three times.

The Vice-President's Trophy, for the best bitch, 38 pounds or over, that has won third prize or better in one of the regular classes. To be won three times.

The Treisurer's Trophy, for the best bitch owned and bred by a member. To be won three times.

The Secret.riy's Trophy, for the best dog owned and bred by a member. To be won three times.

The Kismet Cup, presented by J. H. Brookfield, Esq., for the best dog or bitch in the novice classes. To be won three times.

Tre Seymour Cup, presented by Origen S. Seymour, Esq., for the best dog in the novice class. To be won three times.

The Witerwitch Cup, presented by Sumner C. Denby, Esq., for the best dog winning third or better in the regular American-bred class. To be won five times. 


\section{LIST OF MEMBERS}

Baker, W. E., Jr., 105 West 40th Street, New York City. Bryant, J. N. R., Glen Head, L. I.

Crane, Theo., 15 West 38th Street, New York City.

Dalby, A. B., Chatham, N. J.

Ehrich, H., 43 Exchange Place, New York City.

Ehrich, M. W., 2 Rector Street, New York City.

Echeverria, Dr. M. J., 248 West 76th Street, New York City.

Fuller, Mrs. S. L., 160 East 70th Street, New York City.

Gould, H. W., 73 5th Avenue, New York City.

Graham, J. R., 76 William Street, New York City.

Holter, E. O., 52 Wall Street, New York City.

Kennedy, Miss Maud, 40 East 52d Street, New York City.

Offerman, Theo., 503 Fulton Street, Brooklyn, N. Y.

Patterson, W. F., 100 William Street, New York City.

Proctor, A. B., Orangeburg, N. Y.

Riker, D. S., 46 Cedar Street, New York City.

Rutherford, W., 175 2d Avenue, New York City.

Savage, Dr. W. B., East Islip, L. I.

Seymour, O., 54 William Street, New York City.

Vaughn, W. W., Red Bank, N. J.

Vaughn, Mrs. W. W., Red Bank, N. J.

Wakefield, G., 36 Oakley Arenue, White Plains, N. Y.

Wills, E. C., Greenwich, Conn.

Wodell, S., 149 Broadway, New York City.

Wuismore, R. S., 30 Broad Street, New York City. 


\title{
AIREDALE TERRIER CLUB OF CANADA
}

FOUNDED 1908

\author{
FOUNDERS \\ MESSRS. BAIN, BAND, LAURIN AND BLACK
}

OFFICERS

HUNORARY PRESIDENT

PHILIP BAWDEN

PRESIDENT

JAS. W. BAIN

FIRST VICE-PIEESIDENT

C. S. BAND

SECOND VICE-PRESIDENT

J. F. H. USHER

SECLETARY-TREASURER

J. PERKINS,

1832 Dundas Street, Toronto

EXECUTIVE COMMITTEE
C. L. BOWEN
SID. PERKINS
S. BAMFORD H. CLAYTON

W. C. WALKER

Initiation and Fee, $\$ 3.00$ per aunum.

\section{STANDARD}

The English Standard is adopted by this Club, with scale of points as follows: 


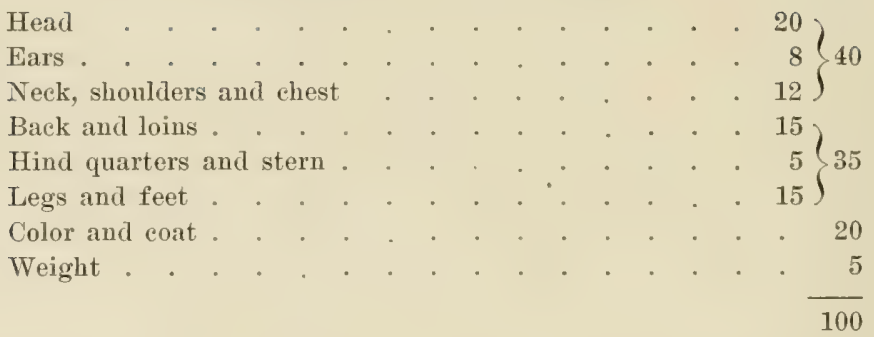

Editorial Note-This Club gives 10 more points from head to chest, 5 more for body, deducts 5 points in the coat and color section and adds weight to its "scale of points" for 5 ; entirely omitting the 15 points for general character, expression of the English Standard.

\section{LIST OF MEMBERS}

Bain, Jas. W., 36 Forest Hill Road, Toronto.

Bain, Jno., Walkerville, Ontario.

Bowen, C. L., Kingston, Ontario.

Billinger, — Boultbee Avenue, Toronto.

Brough, R. W., Dominion Bank, Toronto.

Bamford, S., Humber Bay, Ontario.

Clayton, H., Toronto, Ontario.

Crawford, Mrs. A. E., Evanston, Ill., U. S. A.

Gow, J. P., Guelph, Ontario.

Kenney, R. W., Winnipeg, Manitoba.

Laurin, J. A., Montreal, P. Q.

MeRurry and Melton, Sarnia, Ontario.

Srann, Bert, Humber Bay, Ontario.

Perkins, Jos., Toronto, Ontario.

Perkins, Sid., Toronto, Ontario.

Perrin, C. H., Evanston, Ill., U. S. A.

Turley, J. W., Yorkton, Sask.

Walker, W. C., 'Toronto, Ontario. 


\title{
THE AIREDALE TERRIER CLUB OF LONG ISLAND \\ BROOKLYN, N. Y.
}

ORGANIZED APRIL 16, 1910

\section{OFFICERS}

\author{
PRESIDENT \\ WILFORD WOOD \\ FIRS'T VICE-PRESIDENT \\ JOHN MCGOUGH \\ SECOND VICE-PRESIDENT \\ JOHN RETD \\ THIRD VICE-PRESIDENT AND TREASURER \\ EDMUND EVANS \\ SECRETARY
}

J. N. R. BRYANT,

P. O. Box 31, Glen Head, N. Y.

Dues, $\$ 5.00$ per year

Offers specials, Club medals, cups and cash to principal Kennel Club Shows.

Meets fourth Wednesday of every month, excepting July and August, at rooms in Johnston Building, 8 Nevins Street, Brooklyn, N. Y.

\section{SHOWS HELD}

This C'lub held its first show on April 8, 1911, with Mr. Theodore Offerman as judge, and had 54 dogs benched, representing an entry of 104.

The second show was held May 4, 1912, with Mr. W. E. Baker, Jr., as judge. 


\section{STANDARD}

The Standard adopted by this Club is identical with the English Standard, with the exception of the paragraph on size and the seale of points.

SIzE-Dogs, 10 to 45 pounds weight. Bitches, slightly less. This rule will not apply to dogs or bitches under one year old.

It is the unanimous opinion of the Club that the size of the Airedale Terrier as given in the above Standard, is one of, if not the most important characteristies of the breed; all judges who shall henceforth arjudicate on the merits of the Airedale Terrier: shall consider undersized specimens of the breed severely handicapped when competing with dogs of the standard weight. And that any of the Club's judges who, in the opinion of the committee, shall give prizes or otherwise push to the front dogs of a small type, shall be at once struck off the list of specialist judges.

\section{SCALE OF POINTS}

\begin{tabular}{|c|c|c|c|c|c|c|c|c|c|c|c|c|c|c|}
\hline Head & . & . & . & & & • & . & . & • & . & & & & \\
\hline Ear & . & . & . & . & . & . & . & . & . & - & . & & & \\
\hline Eyes & . & . & . & . & . & . & . & . & . & . & • & & & \\
\hline Month & . & . & . & . & . & . & . & . & . & . & . & & & \\
\hline Neck & . & . & . & . & . & . & . & . & - & . & . & & & \\
\hline Shoulder: & & . & . & . & . & . & . & . & • & . & . & & & \\
\hline Chest & & . & . & . & . & . & . & . & . & . & . & & & \\
\hline Borly & . & . & . & . & . & . & . & . & . & . & . & & & \\
\hline Find qua & arters & . & . & 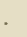 & . & & & . & . & - & • & & & \\
\hline Legs anc & d feet & . & . & . & $0^{\circ}$ & . & . & . & . & . & . & 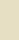 & & \\
\hline Coat. & . & . & . & . & . & . & . & . & - & . & . & & . & \\
\hline Color & . & . & . & . & . & . & . & . & . & . & . & & & \\
\hline General & арреа & aure & & . & . & . & . & . & . & . & . & & & \\
\hline
\end{tabular}

Edtortal Note-The above exception regarding pups does not really mean a change in the Standard, for it is obvious that the weight of a puppy should be less than that of a grown dog, and the standard weight is always interpreted as that of a dog at maturity, in fit condition.

In the seale of points it will be seen that as many points are allowed for the head and neck as the English Standard allows for head, neck, shoulders and chest, and only half as many points are allowed for legs and feet and half as many points for color. 


\section{THE CALTFORNIA AIREDALE TERRIER CLUB}

\section{OFFICERS}

PRESIDENT

J. A. FOLGER

FIRST VICE-PRESIDENT

CARL WESTERFIELD

SECOND VICE-PRESIDENT

CHARLES K. HARLEY

THIRD VICE-PRESIDENT

WM. H. CREED

SECRETARY

NAT. T. MESSER, Mills Building, San Francisco, Cal.

BENCH SHOW COMMITTEE

ALEXANDER RUSSELL, Chairman

CHAS. BUSHBY

WM. H. CREED

DELEGATE TO A. K. C.

G. A. WER'THETMI

Annual Meeting, first Wednesday in February

Initiation Fee, $\$ 5.00$.

Annual Dues, $\$ 50.00$.

\section{STANDARD}

The Standard adopted by this Club is identical with the English Stanclard, with the exception of the paragraph on size which is added below.

Size-Dogs, 40 to 45 pounds weight. Bitches, slightly less.

It is the unanimous opinion of the Club that the size of the Airedale Terrier as given in the above Standard, is one of. if not the 
most important characteristies of the breed. All judges who shall henceforth adjudicate on the merits of the Airedale Terrier shall consider undersized specimens of the breed sererely handicapped when competing with dogs of the standard size. ${ }^{1}$

In reference to the last paragraph of the Standard, it is the opinion of this Club that the Airedale 'Terrier is not governed by weight, for the Standard calls for a dog with plenty of sulstance, and therefore an Airedale Terrier may be of the proper size and good to look at, and weigh easily 10 pounds over 45 pounds. We in California expect the Airedale Terrier to do some pretty tough things, and a dog that only weighs 45 pounds has not a chance in the world with a good-sized cat or a coon. On the other hand, I have seen dogs weighing 50 to 55 pounds do the work much better than dogs that weigh 40 , as far as alertness and quickness in finishing the work required of them are concerned.

1 Editorial Note-It will be seen that the word size has been substituted for weight, and the last sentence of the Standard omitted. 


\section{THE WESTERN \\ AIREDALE TERRIER CLUB}

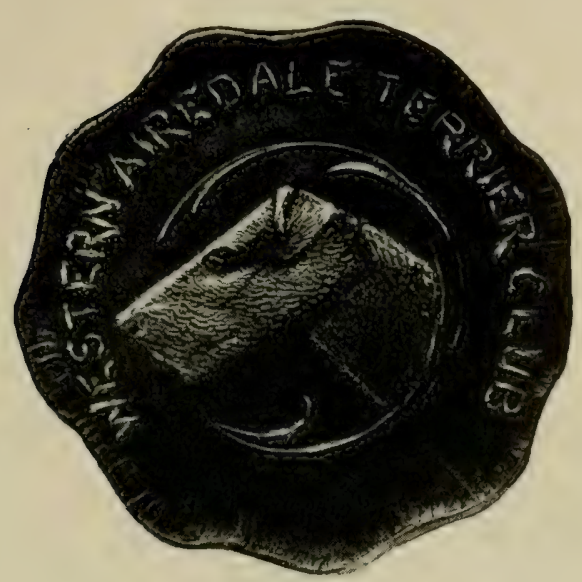

FOUNDED IN 1910

BY EARLE J. WOODWARD AND RALPH W. CONDEE

\section{OFFICERS}

PRESIDENT

DR. C. G. DAVIES

VICE-PRESIDENTS

CHAS. P. ROCKWOOD

E. G. MARQUARDT
SECRETARY AND TREASURER

EARLE J. WOODWARD, 826 Eastwood Avenue, Chicago, Ill.

EXECUTIVE COMMITTEE

DR. C. G. DAVIES

CHAS. P. ROCKWOOD

E. G. MARQUARDT

EARLE J. WOODWARD
RALPH W. CONDEE

DR. C. G. DARLING

EDWIN A. MUNGER

CHARLES H. PERRIN

FRANCIS G. PORTER 
The Entrance Fee to the Western Airedale Terrier Club is $\$ 5.00$; the Annual Dues are $\$ 5.00$.

The Annual Meeting of the Club is held at Chicago, Ill., during the month of December.

\section{THE STANDARD}

The Standard adopted by this Club is identical with the English Standard.

\section{SHOWS HELD}

The following Specialty Shows have been held:

May 30, 1910, Chicago, 27 dogs shown. Mr. Alex. Smith, judge. (Not under A. K. C. rules.)

October 1, 1910, Bismarck Garden, Chicago. First Annual Specialty Show. (Under A. K. C. rules, rated at two points.) Mr. John W. Burton, judge. 48 dogs benched.

September 30, 1911, Bismarck Garden, Chicago, Second Annual Specialty Show. (Under A. K. C. rules, rated at two points.) Mr. Theodore Offerman, judge. 46 dogs benched.

May 30, 1912, Highland Park, Ill. First Amuual Spring Puppy Show. (Not under A. K. C. rules.) Mr. Earle J. Woodward, judge. 25 dogs benched.

September 28, 1911, Bismarck Garden, Chicago, 3d Annual Specialty. (Under A. K. C. rules, rated at four points.) Mr. Edwin A. Munger, Chicago, judge. 55 dogs benched.

The Ammual Specialty Show of the Club is held at Chicago about the first of October in each year.

The Amunal Spring Puppy Show is held on Decoration Day, at or near Chicago.

The Challenge Gold Medal of the Club is offered for competition at any A. K. C. show requesting same. A full list of Club stakes, trophies, ete., may be had by applying to the Secretary.

\section{LIST OF MEMBERS}

Brumnell, F. H., 441 Plymouth Court, Chicago, Ill.

Burton, John W. (Honorary), 32 West 73d Street, Chicago, Ill.

Callaghan, D., 90 Collins Street, Joliet, Ill.

Carmichael, D. L., 113 East 71st Street, Chicago, Ill.

Condee, Ralph W., 1222 First National Bank Building, Chicago, Ill.

Cooke, John A., 628 West 12th Street, Chicago, Ill.

Coyne, Thomas, 141 South La Salle Street, Chicago, Ill.

Crawford, Mrrs. Augusta E., 2735 Sheridan Road, Evanston, Ill. 
Curry, Richard H., Larchmere Kennels, South Hamilton, Mass.

Darling, C. G., M.D., 117 Broadway Avenue, Wilmette, Ill.

Davies, Dr. C. G., 214 High Street, Blue Island, Ill.

Davis, J. F., 1259 Michigan Avenue, Chicago, Ill.

Denby, S. C., Wool Exchange Building, New York City.

Denison, F. G., Ronan, Mont.

Dodds, Dr. R. M., Mankato, Minn.

Downer, George F., Butte, Mont.

Ferguson, Thomas W., Lindenhurst Farm, South Milwaukee, Wis.

Fisher, Frederick A., M.D. (Honorary), 1609 Fullerton Avenue, Chicago, Ill.

Halstead, Dr. A. E., 31 North State Street, Chicago, Ill.

Hanecy, Elbridge, 1222 First National Bank Building, Chicago, Ill.

Harkness, Dr. Grove, Waukesha, Wis.

Henning, W. E., Clinton, Ia.

Herman, Earl L., 1057 Columbia Avenue, Chicago, Ill.

Hill, Dr. Fred W., 619 Oakland Boulevard, Chicago, IIl.

Humphreys, Rogers, Bloomington, Ill.

Hutchinson, W. B., 2703 Prairie Avenue, Chicago, 111.

James, Dr. Robert I., Blue Island, III.

Jensen, B., 1842 North Springfield Avenue, Chicago, Ill.

Jordan, Robert, Box 55, Boston, Mass.

Lusted, Warren, 112 West South Water Street, Chicago, Ill.

Marquardt, E. G., Burlington, Ia.

Morris, Edward, Jr., 4800 Drexel Avenue, Chicago, Ill.

Munger, Edwin A., 35 North Dearborn Street, Chicago, Ill.

Myers, Cornelius T., 49 Pingree Avenue, Detroit, Mich.

Nellegar, Harry C., 175 West Jackson Boulevard, Chicago, Ill.

Offerman, Theodore (Honorary), 503 Fulton Street, Brooklyn, N. Y.

Olesen, S. P., 4112 Newport Avenue, Chicago, Ill.

Parnall, C. G., M.D., Jackson, Mich.

Perkins, L. C., 511 Mulberry Street, Des Moines, Ia.

Perrin, Charles H., 2735 Sheridan Road, Evanston, IIl.

Pick, Edwin, West Bend, Wisconsin.

Porter, Francis G., 29 South La Salle Street, Chicago, Ill.

Randell, J. E., 72 West Adams Street, Chicago, Ill.

Reay, W. M., 237 Michigan Avenue, Chicago, Ill.

Rockwood, Charles P., Box 472, Indianapolis, Ind.

Russum, Thomas, care of Purdy \& Henderson, Monadnock Building, Chicago, Ill.

Schweizer, Adolph, Blackstone Hotel, Chicago, Ill.

Swiney, W. B., 450 East 42 d Place, Chicago, Ill.

White, Dr. C. A. (Honorary), 216 East 26th Street, Chicago, Ill.

Wilson, Louis T., 166 North State Street, Chicago, Ill.

Woodward, Earle J., 826 Eastwood Avenue, Chicago, Ill.

Woolf, Herbert M., 1020 Walnut Street, Kansas City, Mo. 


\section{THE NORTHWESTERN AIREDALE TERRIER CLUB}

FOUNDED 1911

\section{OFFICERS}

PRESIDENT

H. M. TAYLOR, North Yakima, Wash.

FIRST VICE-PRESIDENT

DR. H. V. ADIX, Estaeada, Ore.

SECOND VICE-PIRESIDENT

W. F. DELABARRE, Port Angeles, Wash.

SECRETARY-TREASURER

JAMES G. KEEFE, 27 West Park Street, Butte, Mront.

DIRECTCRS

R. M. PALAIER, 405 Colman Building, Seattle, Wash. GEO. F. DOWNER, Butte, Mont. C. W. J. RECKERS, White Salmon, Wash.

N. C. WESTERFIELD, R. F. D., Oregon City, Ore.

IV. B. BAILEY, Seattle, Wash.

MEMBERSHIP FFE AND DUES

Nerely an annual subseription of $\$ 2.00$, payable Jan. 1.

STANDARD

The standard adopted hy this ('luh is identical with the English Standard. 
This Club was founded April 15. 1911, and its founders were: PRESIDENT

R. M. PALMER, Seattle, Wash.

VICE-PRESIDENTS

NAT MCCONNELL, Vancourer, B. C.

JAS. G. KEEFE, Butte, Mont.

SECRETARY AND TREASURER

GEORGE F. DOWNER, Butte, Mont.

DIRECTOLS

A. J. LUPLOW, North Bend, Ore.

DOUGLAS HUNTINGTON, Seattle, Wash.

No Club Shows have been held.

Chief annual competition: Futurity or Produce Stake. First one, 1912. 19 litters nominated, 14 actual competitors.

First prize, Kootenai Chinook, owned by Kootenai Kennels.

Second prize, Kootenai Tornado, owned by Kootenai Kennels.

Third prize, Kootenai Sirocco, owned by Kootenai Kennels.

Fourth prize, Laddix Lieutenant, owned by Laddix Kennels. 


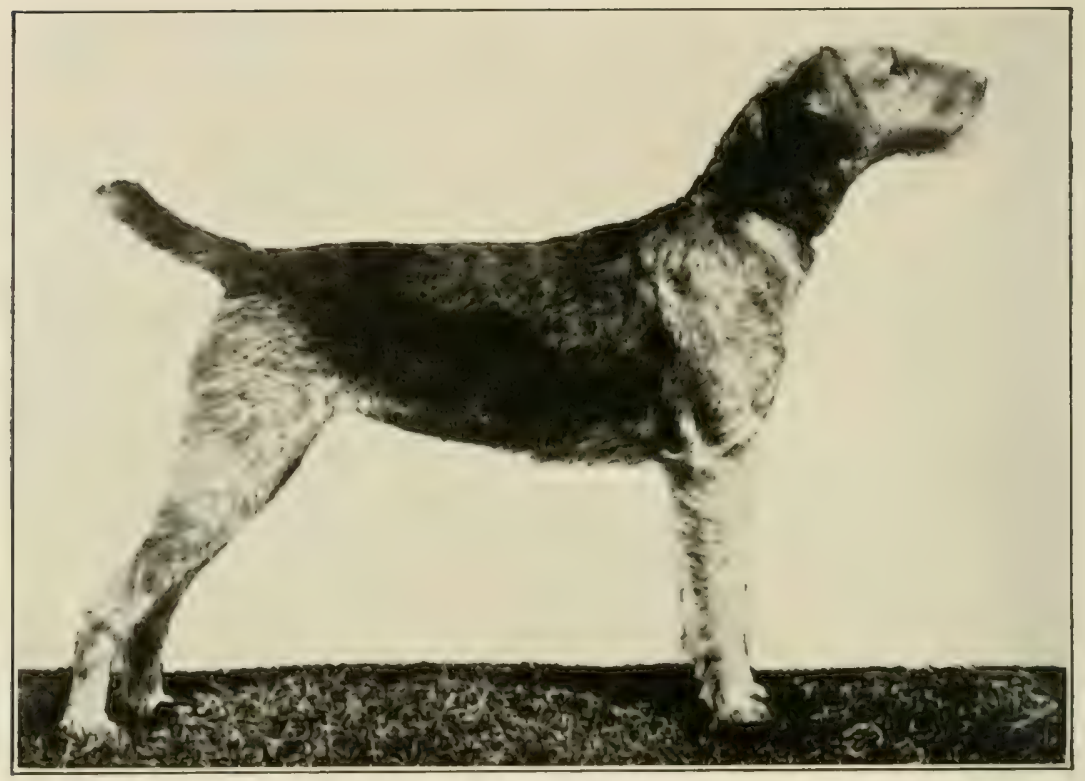

CII. TANGLEWOLD UNA

A. K. C. S. B. $115,89=$

Whelped Dee. 22, 1907. By Ch. Clonmel Monareh ex Pretty Florrie 


$$
-
$$





\section{I3REEDERS' AND KENNEL DIRECTORY}

Abbey Kennels, F. G. Porter, 29 South La Salle Street, Chicago, Ill. Aввотт, W. P., Monsey, N. Y.

Adix, DR. H. V., Laddix Kennels, Estacada, Ore.

Almural, Leon V., Lodge-Pole Ranch, Scholl, Colo.

*Allstone Kennels, Ida H. Garrett, Bound Brook, N. J.

*Arnecliff Kennels, E. C. Wills, Greenwich, Conn.

BムKER, W. E., Hokola Kennels, 105 West 40th Street, New York.

Baker, W. E., Jr., Tanglewold Kennels, 105 West 40 th Street, New York.

BALKWILL, W. W., Stuart, Fla.

Barramax, W. AL., R. F. D. No. 1, Marysville, Wash.

Bawden, P., Caerphilly Kennels, Box 59, Ridgetown, Ontario, Can.

Benton, Chas. Everett, Boston, Mass.

Berwick, WALter M., Shelburne, Ontario.

Besant, Vincent, MeClara Arenue and Grant Street, Butler, Pa.

Blue Jacket Kennels, Oscar G. Davies, Merriam, Johnson County, Kan.

Blunt, E., Midland Kennels, Ivydene, Snarestone, England.

"Bothwell Kennels, A. B. Proctor, Orangeburg, N. Y.

Branson, J. A., Joseph, Ore.

*Brushwood Kennels, John Hopkinson, Iry Depot, Va.

Bryant, J. N. R., Carrolton Kennels, Glen Head, L. I.

Butler, Ormand J., Montrale Kennels, 59 William Street, New York.

Burtenshaw, W. A., Skibo Kennels, 110 Centre Street, New York.

Buckley, Holrand, Clonmel Kennels, Burnham, Bucks, England.

Caerphilly Kennels, P. Bawden, Box 59, Ridgetown, Ontario, Can.

"Carrolton Kennels, J. H. R. Bryant, Glen Head, L. I.

Chief Kenvels, F. G. Dennison, Ronan, Mont.

Clark Rossiter and Buford, Ruby Valley Kennels, Sheridan, Mont.

Calder Bank Kennels, Daniel S. Riker, P. O. Box 1393, New York City.

Cionmer Kexnels, Holland Buckley, Burnham, Bucks, England.

Coвb, Clyde, Flathead Kennels, Kalispell, Mont.

Condy, E. Bines, Huckleberry Kennels, Taunton, Somerset, Fingland.

Crawford, Mres. A. E., Vickery Kennels, Eranston, Ill.

Cresco Kennels, J. D. Sterrett, Erie, Pa.

Crowgit. Kenvels, F. M. Jowett, Shipley, Yorkshire, England.

Curtis, W. H., Jr., Horfield Bakery, Bristol, England.

Dargle Kexieis, Wallace Marrs, Horley, Surrey, Englani.

Divies, Oscap G., Blue Jacket Kennels, Merrimam, Kan.

Dretz, S. D., R. F. D. No. 4, Grand Junetion, Colo.

Deidi Kexnels, F. A. Eyth, Box 234, Butler, Pa.

Dennisox, F. G., Chief Kennels, Ronan, Mont.

Dodns, R. M., Gopher Kennels, Mankato, Minn.

Downer, Geo. F., Kootenai Kennels, Butte, Mont. 
Duncan, James W., Box 107, MeKeesport, Pa.

Dunlevy, Frank H., 3021 7th Ave. Parkway, Denver, Colo.

*Eden Hill Kennels, Silas Wodell, Millbrook, Dutchess Co., N. Y.

*Empost Kennels, E. M. Post, 111 Broadway, New York.

Evans, Edmond F., 9 Highview Ave., Jamaica, N. Y.

Eyth, Frank A., Delhi Kennels, Box 234, Butler, Pa.

Flathead Kennels, C. Cobb, Kalispell, Mont.

Forbes, Dr. E. A, State Veterinarian, San Angelo, Tex.

French, Geo. Jackson, Spicelands Kennels, Rochester, N. Y.

Garrett, Mrs. IdA H., Allstone Kennels, Bound Brook, N. J.

Gates, Mrs. Merrill E., Jr., Malvern Kennels, Bedford Hills, N. Y.

Gopier Kennels, R. M. Dodds, Mankato, Minn.

Greenberg, Sam, Everett, Washington.

Greer, George, 126 Madeline St., Lakeview, Paterson, N. J.

IIAlste.d, Lieut. A. E., Halstead Farm Kennels, 31 N. State St., Chicago, Ill.

Halstead Farm Kennels, A. E. Halstead, South Haven, Mich.

Hauser, Dr. G. F., La Crosse, Wis.

Hello Kennels, E. A. Wheatley, Chattanooga, Tenn.

Hillyer-Labouchere, Mrs. L., Liphook, Hants, England.

*Hokola Kennels, W. E. Baker, 105 West 40th Street, New York.

HoLt, J. M., Marshalltown, Iowa.

Hopkinson, John, Brushwood Kennels, Ivy Depot, Va.

Huckleberry Kennels, E. Banes Condy, Taunton, Somerset, England.

Humphreys, Rogers, Midoaks Kennels, Bloomington, Ill,

Johrston, Dr. J., Ritzville, Washington.

*Jordan, Robert, Larchmere Kennels, Box 55, Boston, Mass.

Jowetт, F. M., Crowgill Kennels, Shipley, Yorkshire, England.

Keefe, James G., Mountain View Kennels, Butte, Mont.

Kenmare Kennęlis, W. P. Wolcott, Readville, Mass.

Kissane, Thomas; Whitehall, N. Y.

Kootenai Kennels, G. F. Downer, Butte, Mont.

${ }^{*}$ Laddix Kennels, Dr. H. V. Adix, Estacada, Ore.

*Lake Dell Kennels, R. M. Palmer, Seattle, Wash.

*Larchmere Kennels, Robt. Jordan, South Hamilton, Mass.

*Malvern Kennels, Mrs. M. E. Gates, Bedford Hills, N. Y.

Marrs, Wallace, Dargle Kennels, Horley, Surrey, England.

Mayes, WM. A., Mt. Penn, Pa.

Messer, Nit. T., Thayerdale Kennels, 3024 Prince Street, San Francisco, Cal.

Midodks Kennels, R. Humphreys, Bloomington, Ill.

Montvale Kennels, O. J. Butler, Montvale, N. J.

Morledge, Geo. E., 8th and York Streets, Newport, Ky.

* Mountain View Kennels, J. A. Keefe, Butte, Mont.

Mrers, Thomas G., Utica, Mont.

Newton, Walter S., Calgary, Alberta, Can.

OBer, Harold, 70 Fifth Avenue, New York.

Orchid Knoll Kennels, J. W. Spring, Boston, Mass.

*Otis Kenneis, C. P. Rockwood, Indianapolis, Ind.

Palmer, R. M., Lake Dell Kennels, 405 Coleman Bldg., Seattle, Wash. 
PAtTerson, W. F., South Mountain Kemnels, 100 William Street, New York.

Pequad Kennels, H. A. Purrington, Pequabuck, Conn.

Perrin, C. H., Vickery Kennels, Evanston, Ill.

*Pitcairn Kennels, O. S. Thompson, East Orange, N. J.

Pomeror, De Forest, Tonka Kennels, 617 Security Bank Blig., Minneapolis, Minn.

Porter, Francis G., Abbey Kenuels, 29 South La Salle Street, Chicago, Ill.

Post, Edwin Main, Empost Kennels, 111 Broadway, New York.

Proctor, Arthur Bothwell, Bothwell Kennels, 15 W. 38th Street, New York.

Purrington, Herbert A., Pequad Kennels, Pequabuek, Conn.

Rockwood, Chas. P., Otis Kennels, P. O. Box 472, Indianapolis, Ind.

Riker, Daniel S., Calder Bank Kennels, P. O. Box 1393, New York.

Ruby Valley Kennels, Clark Rossiter and Buford, Sheridan, Mont.

Sharp, Walter C., 303 Cole Bldg., Nashville, Tenn.

*Skibo Kennels, W. A. Burtenshaw, 341 Morgan Avenue, Brooklyn, N. Y.

Sмiтh, W. S., 548 East Albion Street, Appleton, Wis.

Sotavint Kennels, A. Volkenning, San Andres Tuxtla, Vera Cruz, Mexico.

*South Mountain Kennels, W. P. Patterson, Maplewood, N. J.

Spencer, Dr. Geo. A., Sacramento, Cal.

SPICelands Kennels, G. J. French, Rochester, N. Y.

Sterrett, J. D., Cresco Kennels, Erie, Pa.

Stokes, Thos. P., Penllyn, Pa.

SPring, James W., Orchid Knoll Kennels, Tremont Bldg., Boston, Mass.

*Tanglewold Kennels, W. E. Baker, Jr., 105 West 40 th Street, New York.

Taylor, Henry H., Bridgeport, Conn.

*Thayerdale Kennels, Nat. T. Messer, 3024 Prince Street, San Francisco, Cal. Thompson, Owen S., Piteairn Kennels, East Orange, N. J.

Timmerman, W., Manning, Iowa.

Toney Kennels, 2914 South Vermont Avenue, Los Angeles, Cal.

Toner, Dr. L. C., Toney Kennels, Los Angeles, Cal.

*Tonka Kennels, De Forest Pomeroy, Minneapolis, Minn.

Vickert Kennels, Perrin and Crawford, Barrington, Ill.

Volkenning, Alfredo, Sotarent Kennels, San Andres Tuxtla, Vera Cruz, Mex.

West, George S., Chestnut Hill, Mass.

Wheatley, E. A., Hello Kennels, Chattanooga, Tenn.

Whittaker, Geo. P., Windy Moor Kennels, Wheeling, W. Va.

Wills, ERnest, Arnecliff Kennels, Greenwich, Conn.

Windy Moor Kennels, G. P. Whittaker, Wheeling, W. Va.

Wodeld, Silas, Eden Hill Kennels, 149 Broadway, New York.

Wolcott, Wr. Prescotr, Kenmare Kennels, Readville, Mass. 


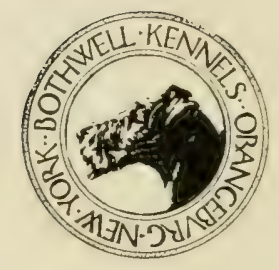




\section{CLASSIFIED ADVERTISEMENTS}

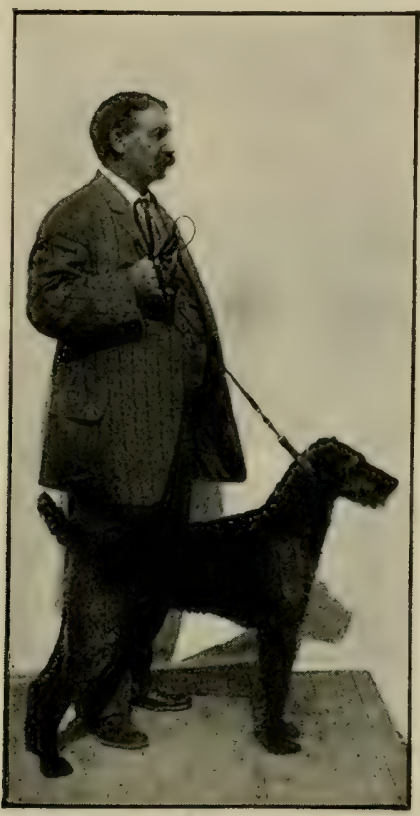

THE I.ATE AIEX SMITH

WITH CH. TINTERN ROYALIST

WE wish to call the reader's attention to the gentlemen who have advertised in the following pages, for it is owing to their liberal support that this book is largely made possible. We would deem it a favor if, in writing them, you would mention having seen their ads. in this book. 


\section{The Complete Story of the Airedale Terrier}

COPIES of this book will be sent 1 postpaid on receipt of remittance of one dollar and fifty cents for America and of six shillings for England.

The numbered Edition de Luxe, consisting of twenty-five copies, printed on bond paper, bound in limp leather, with subscriber's name on cover, autographed by the author, and containing no display ads., will be sold for ten dollars.

The Subscribers' Edition is limited to a thousand copies, will soon be exhausted, and every owner of an Airedale Terrier should have one in his library.

Orders should be sent to
A. B. PROCTOR

ORANGEBURG

- - NEW YORK 


\section{KENMARE KENNELS READVILle, MASS.}

The Leading Airedale Kennel of the East The Home of the Famous Bitch

\section{Champion Kenmare Sorceress}

I9II-I9I2 Winner at the New York Show; in the latter year winning Best of all Breeds, Either Sex.

\section{AT STUD}

\section{Champion Soudan Swiveller}

Who won his championship under six different judges at six successive shows. The ideal mate for large, coarse, light-coated bitches, and particularly those with bad heads and eyes. He is the Sire of the latest sensation, Abbey King Nobbler.

\section{Champion Soudan Stamboul}

An undefeated champion and a dog with the greatest foreface in America, with wonderful bone and substance. Served to small, light-boned, weak-muzzled bitches, he is sure to improve the strain.

Both these dogs are outcrosses of the Oorang Strain.

All fees, $\$ 25.00$.

Puppies by these Dogs out of Champion Bitches for sale.

\section{WILLIAM PRESCOTT WOLCOTT OWNER}




\section{ViCKeRY KenNeLS \\ OFFER AT STUD}

The Wire-Haired Fox Terriers

Champion Vickery Wire Result Vickery Fast Freight and Vickery Revoke

Fee, $\$ 25.00$ Each

The Irish Terrier Vickery Red Sand

$\mathrm{Fee}, \$ 25.00$

The English Setter

Champion Mallwyd Ned

Fee, $\$ 35.00$

Ship all bitches to S. Lomas, Manager

BARRINGTON, ILLINOIS

CRAWFORD \& PERRIN, Owners 


\title{
ViCKERY KENNELS
}

World Famous Airedales

The Home of the Famous Brood and Show Bitch

\section{CH. LARCHMERE Mistress MAGneT}

\author{
At Stud
}

THE INTERNATIONAL CHAMPIONS

\section{Ch. Prince of York Ch. Tintern Royalist}

ALSO

The Great American-bred Son of Tintern Royalist VICKERY LODESTAR

(See pictures of these dogs in book.)

Fee, Each, $\$ 25.00$

Young Stock Always on Hand

Address

VICKERY KENNELS, Barrıngton, Illinois

Property of CRAWFORD \& PERRIN 


\section{CROW GILL KENNELS}

SHIPLEY, YORKS, ENGLAND

\section{Airedale Terriers AND IRISH TERRIERS} A SPECIALTY

Show Stock of the highest quality and Brood Bitches in whelp usually for sale.

Commissions for the purchase of show dogs for exportation carefully executed.

\section{Mr. F. M. JOWETT}

\section{Owner}




\section{Bothwell KenNels \\ ORANGEBURG, N. Y.}

\section{“QUALITY TERRIERs"}

\section{AT STUD - FEE $\$ 15.00$ \\ BOTHWELL BUILDER}

Sire, Ch. Prince of York

Dam, Ch. Briars Masterpiece Bitch

A BLUE RIBBON WINNER AT LONG BRANCH, AMBLER, RUIISON AND PLAINFIELD. JUDGED BY MESSRS.

DALBY, MCCREA, MULFORD AND OFFERMAN.

IF USED TO SMALL-BONED, WEAK-MUZZLED, SOFTCOATED AND SHY BITCHES, HE IS SURE TO IMPROVE YOUR STRAIN, AND SHOULD GET SOME GOOD WINNERS.

PUPPIES FOR SHOW AND PALS, OF THE FINEST AND MOST CAREFULLY SELECTED STOCK, OCCASIONALLY FOR SALE.

\section{CHOW CHOW PUPPIES}

OCCASIONALLY FOR SALE

\section{ARTHUR B. PROCTOR}

15 West 38th Street NEW YORK 


\section{Mountain View Airedales}

\section{Winners and Workers}

Known everywhere as game dogs, they combine size, bone, quality, and type. Young Stock of rare quality and the best breeding at a reasonable price.

\section{AT STUD}

Volunteer, a double Clonmel Monarch cross - $\$ 15.00$ Despot, a double Oorang cross _ _ _ _ . - 15.00 Rory, a double Midland Royal cross - - . 15.00

\section{MOÜNAIN VIEW KENNELS}

Box $334 \quad$ - $\quad$ - $\quad$ - $\quad$ - $\quad$ - Butte, Montana

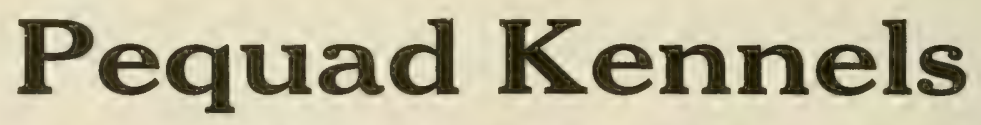
Airedales Exclusively

Best Blood obtainable. Prices reasonable.

HERBERT A. PURRINGTON, Pequabuck, Conn. AT STUD-FEE $\$ 20.00$

The Imported Airedale Terrier Colne Premier OORANG

No. 154,925

Sired by Ch. Crompton Oorang, England's Leading Sire, ex Queen of Pearls, by Ch. Crompton Marvel. Has some winning pups in England. People desiring or wanting to buy a first-class puppy, address

WM. TIMMERMAN, Manning, Iowa 


\section{The International Champion Airedale Terrier}

Property of A. Albright, Jr., Esq.

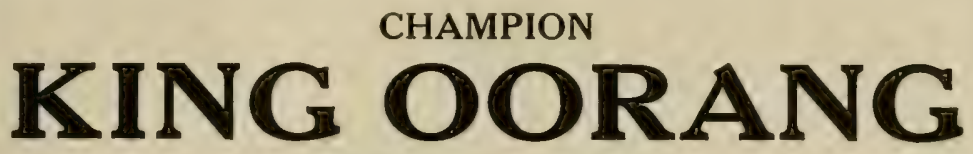

A.K.C.S.B. No. 147,494

Sire, Ch. Rockley Oorang by Ch. Crompton Oorang

Dam, Coronation Brilliant by Ch. Watland's Marvel

\section{Stud Fee, $\$ 20.00$}

Correspondence to

KENNEL MANAGER, 56 Ferry St., NEWARK, N. J.

\section{AIREDALES}

FARM-RAISED PUPPIES, ROYALLY BRED FOR

SHOW, COMPANION, or SPORTING

PURPOSES AS YOU MAY REQUIRE

Prices most reasonable

WINDY MOOR KENNELS WHEELING, WEST VA.

\section{PORTRAIT MODELS OF DOGS IN BRONZE \\ Made from Photographs \\ CHARLES MACKARNESS}

ARROCHAR, STATEN ISLAND, NEW YORK 


\section{The Famous \\ CLONMEL KENNELS}

BURNHAM, BUCKS, ENGLAND

The above have at all times a number of classical specimens of the bluest blood for sale. They comprise Champions of both sexes; brood bitches in whelp or ready to serve; puppies fit to win at the highest class exhibitions. And all at moderate prices, with full consideration for the class of Clonmel Stock, which is famous the world over.

\section{Apply to \\ MR. HOLLAND BUCKLEY Burnham, Bucks, England}

\section{KOOTENAI AIREDALES}

Are Winners from Coast to Coast and Wonderful Workers

\section{ELRUGE MONARCH}

(Note cut facing page 68)

CH. KOOTENAI CHINOOK ENDCLIFFE PERFORMER LAKEVIEW CLIPSTONE PRIDE

Comespondence invitud

KOOTENAI KENNELS, Registered BUTTE, MONTANA, U.S.A.

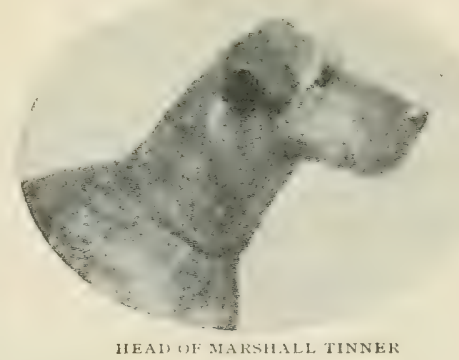

\section{FLATHEAD KENNELS}

Dogs that Tree and Stay

Hunting instinct a specialty. None but the best kept in FLATHEAD KENNELS. Record, 7 bear in 5 days. Imported sires and dams. Imported Marshall Tinner at stud-a sire that has done more to advance the standard of the Airedale than any known sire in America; long heads, heavy bone, black saddles, and all terrier. C. $\mathrm{COBB}$, 


\section{TANGLEWOLD}

This kennel is one of the oldest in America and has been a consistent breeder of winning Airedales for many years.

No other proof of any kennel's claim to breed high-class stock conforming to the standard of the breed, other than the record of the stock it has bred on the show bench, is worth consideration.

Ch. Tanglewold Una, Ch. Clonmel Monarch's best daughter, the sensational winner of 1909 ; Tanglewold Briar Test, best American-bred brought out in I9го; repeatedly placed reserve winners to Prince of York and Tintern Royalist; Hot, and many others, emanated from this kennel. Also the home of the famous brood bitches, Pretty Florrie and Brosna Bacchante.

\section{W. EDGAR BAKER, Jr., 105 W. 40th St., N. Y. City}

\section{AMERICAN KENNEL GAZETTE}

Published Monthly. Official Awards of Shows; Registrations; Bench Show Fixtures; Reports of A.K.C. Meetings, etc. Necessary to Breeders and Exhibitors.

1 LIBERTY STREET NEW YORK CITY 


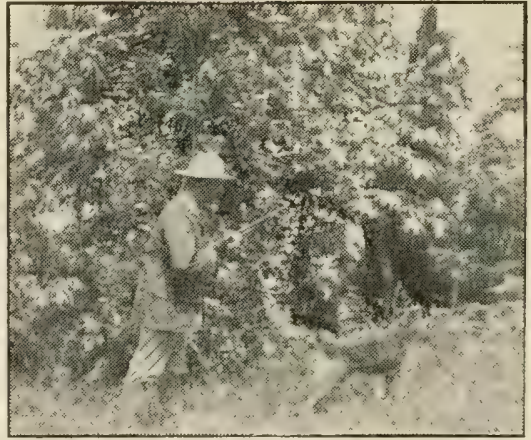

Quail shooting with Lake Dell Dick on Puget Sound

\section{THE LAKE DELL KENNEL}

breeds the best working Airedales in America, the ideal "pal" of the sportsman or country gentleman.

If you want an Airedale Puppy that, when matured, will hunt upland game birds, water fowl, or big game, write

\section{R. M. PALMER}

(Author of "All About Airedales")

Colman BIdg., Seattle, Wash.

The Popular Book

\section{All About Airedales}

\section{By R. M. Palmer, A.B.}

is full of most valuable information about Airedales and profusely illustrated with pictures of rare hunting scenes of Airedales at work on game, with interesting stories of hunting experiences with Airedales.

Everything that interests Airedale fanciers. One reader wrote, "I read it from cover to cover before putting it down. If I could not get another book, it would be priceless to me."

Price, ONE DOLLAR, postpaid

Address: A-A-A PUBLISHING CO.

405 Colman Bldg.

Seattle, Washington

\section{J. F. GALLOWAY \\ 95 Tappan St., - - Kearney, N. J.}

Professional handler of all breeds of dogs. All breeds boarded, prepared for, and skilfully handled at bench shows.

\section{Specialist on all breeds of Terriers}

requiring expert dressing, stripping and trimming. Write for terms. Every dog entrusted to me will be put down fit to win on the day. 


\section{"LADDIX KENNELS"}

Represent the Acme of Perfection in Airedale Blood Lines

The home of

\section{Champion Red Raven-the Stud Wonder}

For prepotency of the CLONMEL MONARCH blood, as a stud producing "like from like," as a shower, as a sire of "the type de Luxe," he is unexcelled. See illustration, page 96; note the largest forefaced Airedale living, the short back, big bone, and general style. You will get that in your next litter from him. Sired four litters 23 males, 8 females-within six days, 1912. Won cup for best Airedale, Kansas City Specialty Show, rgr2. It pays to get the best.

Fee $\$ 25.00$.

Other studs - LADDIX LEVELER, LADDIX LIEI'TENANT, LADDIX DEFIANCE, LADDIX LUCIFER, Champion Crompton Oorang, Master Briar and Master Royal Blood. Good ones. Fees $\$ 20.00-\$ 15$.00.

Bitches in whelp, spayed bitches, adult and young stock of the best strains always for sale. WINNERS ALL THE TIME.

LADDIX KENNELS, H.V. Adix, M.D., Owner, Estacada, Ore.

America's Leading Kennel Journal

\section{THE \\ AMERICAN STOCKKEEPER}

Conducted on True Fanciers' Lines. The Best Dog Chat and Show Reports

Weekly, \$1.00 per year

30 BROAD STREET - - BOSTON, MASS. 


\section{PitCAirn KenNels}

(REGISTERED)

Breeders, Exhibitors and Importers of Highest

Quality Airedale Terriers

EAST ORANGE, N. J.

OWEN S. THOMPSON - - - Proprietor

\section{CH. WissahiCKON CHIEF}

\section{A.K. C. 122,107}

Sire, Ch. Riding Master. Dam, Lady Norah.

Comprising Double Cross Clonmel Monarch blood.

This dog without a doubt the best Americanbred (hampion at stud to-day. FEE, $\$ \mathbf{1 5 . 0 0}$ Stud card and particulars.

E. F. WATSON, 129 Michigan Avenue, Detroit, Mich.

\section{TONEY KENNELS}

FOR SALE - AIREDALES. (hampion Lake I) Il I)amsel, in whelp by Endcliffe Briarwood, ex Lake Dell Dutchess, A.K.C. I I0,966, and by Champion Natlock Bob, E.K.C. 325 and C.K.C. Io, I IO and A.K.C. I 1 7,733. Sire of noted winners. Also Endcliffe Briarwood, ex Beldon Lady, and by Briarwood, B.A.K.C. 982. Puppies of all ages usually on hand.

Prices reasonable

DR. L. C. TONEY, or TONEY KENNELS

No. 2914 S. Vermont Ave.

Los Angeles, California

\section{CheltenhaM KENNELS}

Puppies ( 5 gns. upwards) and Adults (Io gns. upwards) always for sale for home or abroad; bluest blood extant; for exhibition, companions, guards, anc sport; trained by gamekeepers and farmers. Also at Stud - CHELTENHAM CADET, 5 gns.; CHELTENHAM MONARCH, 2 gns.; CHELTENHAM ERIC, I $1 / 2$ gns.

For further particulars apply by letter (no post-cards) to

"Kennelman," co Leonard Petrie, Esq., Gayton, Cheltenham 


\section{Delhi Airedales}

Descent direct from famous $\mathrm{Ch}$. Cholmondeley Briar, father of the breed. None more royally bred. Combine all the leading Championship Sires of England and America. Puppies and grown stock at ail times. Pedigree on application. $\$ 25.00$ will make one of these perfect Airedales yours.

\section{DELHI AIREDALE KENNELS}

Frank A. Eyth

Butler, Penna.

\section{After All, No Dog Like a Good One}

Always have on hand a number of High Class Puppies, PrizeWinning Young Stock, Stud Dogs, Brood Bitches, in whose registered pedigree appear the world's famous Airedales. For further particulars, wite to

EDMOND F. EVANS, 9 Highview Avenue, Jamaica, New York

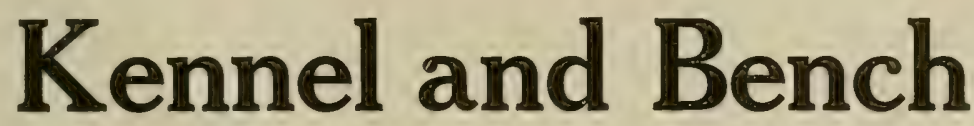

\section{The Official Organ of the Canadian Kennel Club}

Reaching every member of the Canadian Kennel Club in Canada, and every exhibitor, whether member or not. A splendid medium for getting at a large and fast increasing body of dog men.

Subscription price, $\$ 1.00$ per year. Issued monthly. Advertising terms on application

\section{Dr. Alfred Boultbee, Editor}




\section{THE CELEBRATED \\ HUCKLEBERRY KENNELS}

Creech St. Michael,

Taunton, Somerset,

England

Will supply you with Airedales of the highest quality at fair prices.

Apply to E. BANES CONDY

\section{THE "DARGLE" AIREDALES}

The Essence of Correct Type, Quality and Gameness COMPRISING

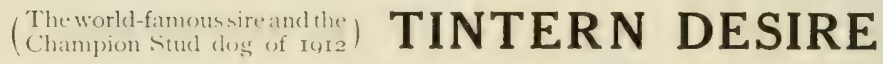
AND

(IIis only serious rival of the $)$ DARGLE DECLARE

ALSO

CHAMPION DARGLE DEPUTY, CHAMPION FERRYHILL FLYER, FFYR-NANT-BEAUTY,

DARGLE MAID, DARGLE DELEGATE, DARGLE DEMURE, DARGLE DIMSHIE, etc.

The most formidable team of show Airedale bitches in the world.

Adults and puppies of both sexes, bred from, or the same way as, the above, can be supplied either for exhibition or breeding purposes-BROOD BITCHES A SPECIALTY - at lowest possible prices consistent with requirements.

\section{Apply to Manager, "DARGLE KENNELS"} c/Mr. Wallace Marrs

Cable, "Wallimars, London"

Horley, Surrey, England 


\section{Montvale Airedale Kennels} ORMOND J. BUTLER, Owner

Puppies and Grown Stock for Sale

Montvale, Bergen County, New Jersey

25 miles from New York City, on New jersey and New York Branch, Erie Railroad.

Also 59 William Street, New York City. Phone, John 3352

\section{Sotavent Airedale Kennels Registered}

ALFREDO VOLKENNING, Owner

Puppies and Grown Stock for Sale

San Andres, Tuxtla, Vera Cruz, Mexico

\section{The}

Southern Kennel

The Dog Journal of the South

Norfolk, Va.

Subscription - - \$I.0O per year

A. R. RAWLETT, Publisher

Now in its $3 \mathrm{~d}$ year 


\section{The Otis KenNels}

\section{"FEWER and BETTER TERRIERS $"$}

Box 472, INDIANAPOLIS,

INDIANA

\section{THE AIREDALE TERRIER KENNELS LIPHOOK, HANTS}

\section{Owner, Mrs. L. Labouchere-Hillyer}

Pedigree stock bred from all the winners of to-day. Puppies and adults, fit for keenest competition, or as companions and guards, always for sale at these kennels. The dogs may be seen by appointment at any time.

Kennelman, L. LATCHFORD

\section{AIREDALE TERRIERS}

Bred for Size, Bone, Coat, Gameness and Strength

Terriers with substance and constitution to stand the hardest usage and bred and trained for hunters, guards and pals. Especial attention and study given in mating to produce the best, and all my dogs are raised on my ranch under my personal supervision, and live and are trained in the open.

Winners and Hunters whose pedigrees contain the blood of such stud dogs and champions as Elruge Monarch, Clonmel Monarch, Tintern Desire, Tintern Monarch, Crompton Oorang, Cherry Royal, Midland Royal, Clonmel Chilperic, Master Briar, Endcliffe Radiance and others equally famous.

Use my dogs at stud and buy my puppies if you want terriers with stamina, strength and size. Correspondence solicited and satisfaction guaranteed.

R. F. D. No. 4

\section{S. D. DIETZ}

R. F. D. No. 4

Grand Junction, Colorado 






$$
\text { (1) }
$$
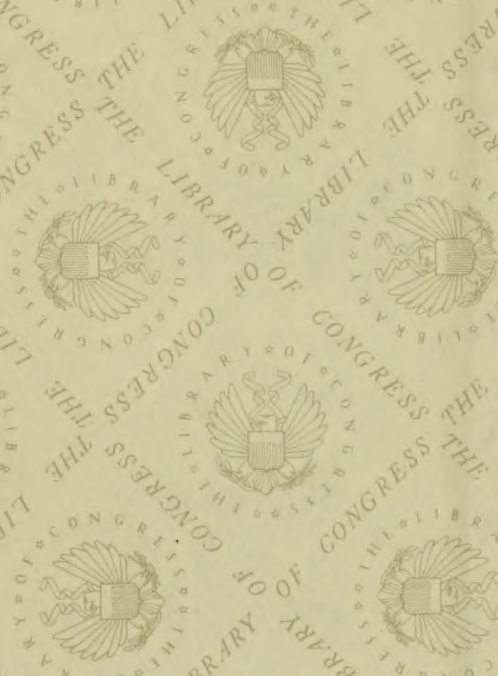


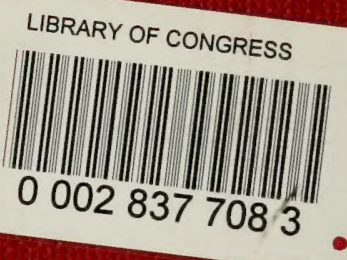

